\title{
ENHANCED BIOBUTANOL PRODUCTION IN BATCH SIMULTANEOUS SACCHARIFICATION AND FERMENTATION FROM AGRICULTURE RESIDUES USING NOVEL CLOSTRIDIAL FUSANTS
}

\author{
by \\ SARKAR BEGUM \\ B.Sc. Engineering in Chemical Engineering \\ Bangladesh University of Engineering and Technology, Bangladesh, 2003
}

A Thesis

presented to Ryerson University

in partial fulfilment of the requirements

for the degree of

Master of Applied Science

in the Program of

Chemical Engineering

Toronto, Ontario, Canada, 2012

(C) Sarkar Begum, 2012 


\section{AUTHOR'S DECLARATION}

I hereby declare that I am the sole author of this thesis. This is a true copy of the thesis, including any required final revisions, as accepted by my examiners.

I authorize Ryerson University to lend this thesis to other institutions or individuals for the purpose of scholarly research.

Sarkar Begum

I further authorize Ryerson University to reproduce this thes is by photocopying or by other means, in total or in part, at the request of other institutions or individuals for the purpose of scholarly research.

I understand that my thesis may be made electronically available to the public.

Sarkar Begum 


\title{
ABSTRACT \\ Enhanced Biobutanol Production in Batch Simultaneous Saccharification and Ferme ntation from Agriculture Residues using Novel Clostridial Fusants
}

\author{
Sarkar Begum \\ Master of Applied Science \\ Chemical Engineering \\ Ryerson University \\ 2012
}

A novel approach was introduced for the enhancement of biobutanol production in $\mathrm{ABE}$ fermenetation. Thermostable Clostridia species were developed through protoplast fusion between mesophilic and thermophilic Clostridial species. Two parental strains of Clostridia species, Clostridium acetobutylicum (ATCC 4259) and Clostridium beijerinckii (ATCC BA101), along with three fused strains, Clostridium acetobutylicum Clostridium thermocellum (CaCt), Clostridium beijerinckii Clostridium thermocellum ( $\mathrm{CbCt}$ ) and Clostridium acetobutylicum Clostridium beijerinckii $(\mathrm{CaCb})$, were examined for biobutanol production using wheat straw as a feed stock in a batch process of simultaneous saccharification and fermentation (SSF). The objective of the study was to use the thermotolerant fused strains to enhance enzymatic activity during the SSF by raising the incubation temperature and thereby eventually increasing biobutanol production. Economic and residence time analysis of SSF found that addition of cellulase increases the cost of fermentation and prolongs biobutanol production cycle. However, results from the current study indicated that the fused strains, at the higher temperature, were able to produce the required enzymes for the saccharification of wheat straw (i.e., endoglucanase, exoglucanase, and b-glucosidase). This will have a major impact on eliminating costs as sociated with adding enzymes as raw material to the saccharification process. Fused strain $C b C t$ achieved the highest biobutanol production of up to $14.13 \mathrm{~g} / \mathrm{L}$ (i.e., a yield of 0.29) was reached at $45^{\circ} \mathrm{C}$ with total sugar consumption of $82 \%$. Enzymatic activity of $C b C t$ was found to be 61.67 FPU (Filter Paper Unit) which was the highest in comparison with other fused strains evaluated in this study. These results indicate a breakthrough for the technological and economical obstacles associated with industrialization of the SSF process. 


\section{ACKNOWLEDGMENTS}

I consider that this is the most significant page of this thesis. Although, there are no results described on it, I can express my gratitude to the people who have contributed to the good end of this project.

I would like to show my sincere gratitude to my supervisor Dr. Yaser Dahman for giving me the opportunity to work on this project. Without his continuous support, help and encouragement I could not have completed it on my own. This has been an enhancing experience for me, I have learnt to have a broader look at a scientific aspect and I have met many colleagues. I would like to thank my supervisor again for appointed me as a teaching assistant.

I would like to give thanks to my colleagues Wahib Al Abdallah, Hamza Nakhoda, Muhammad Ferhan, Hadeel Al Neddaff and Kashif Syed for their ready to help attitude. I felt free to discuss my project with them. They made a friendly environment in the lab which gave me pleasant satisfaction to work on my project.

I am thankful to the microbiology lab and analytical lab for a constant willingness to help. Special thanks to Shahnaz for her help with the centrifuge and to Shawn on the crimper. I am grateful to Firas Farah for helping me out to take the pictures during experiment.

I wish to thank my family and my parents for their unconditional support and love. Their understanding is greatly appreciated; I would like to dedicate this work to them. 


\section{TABLE OF CONTENTS}

Page

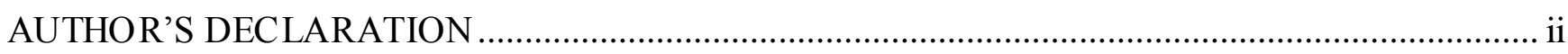

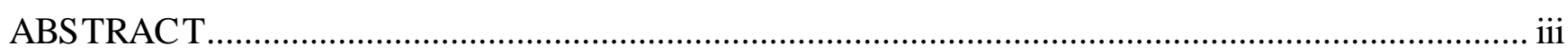

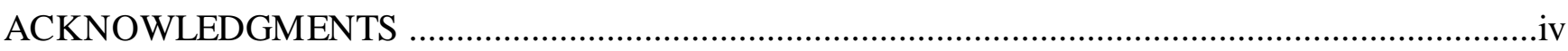

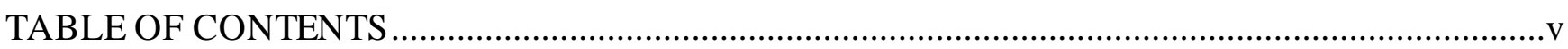

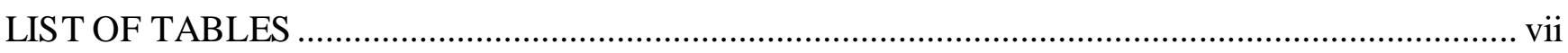

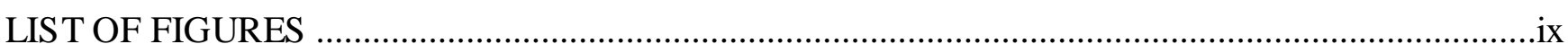

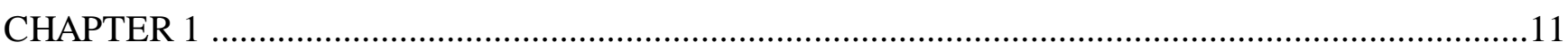

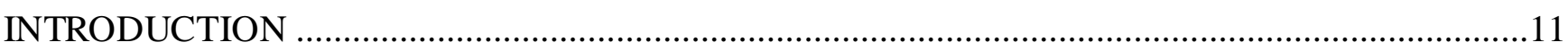

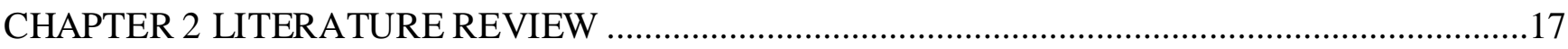

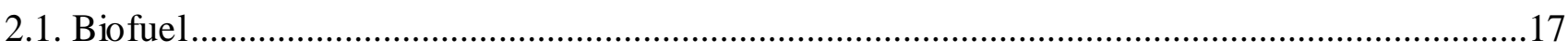

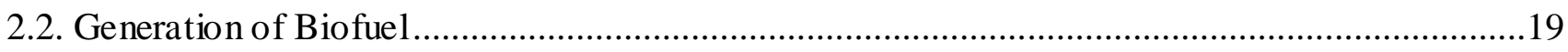

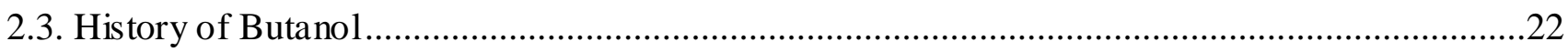

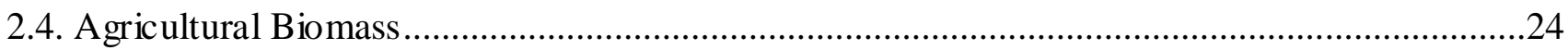

2.5. Clostridia and Fermentation Metabolism of Butanol ..............................................................27

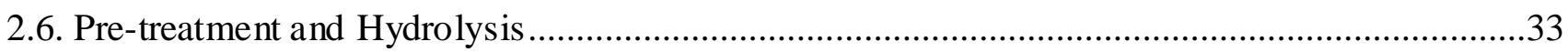

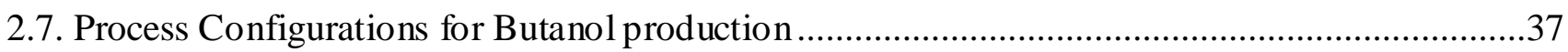

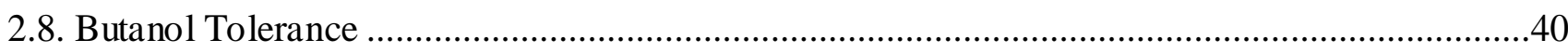

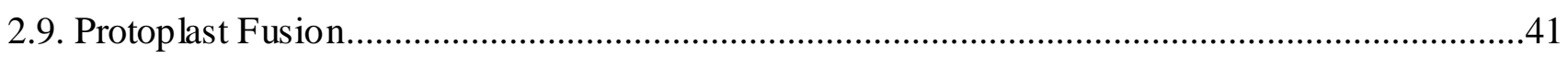

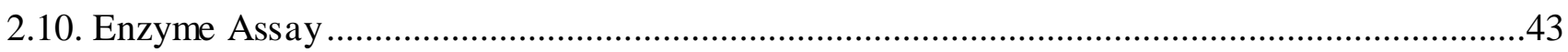

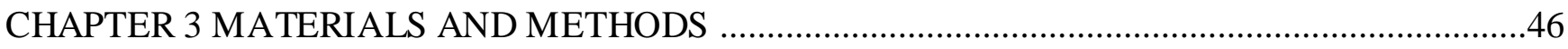

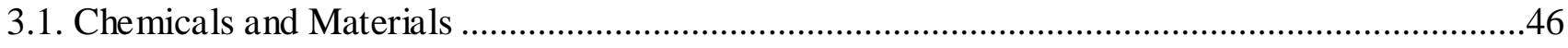

3.2. Preparation and Hand ling Protoplast Fused Strains ..........................................................47

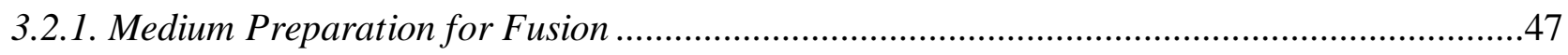

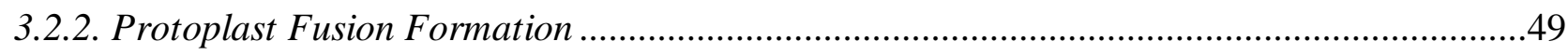

3.3. Inocula Preparation and Culture Conditions .........................................................................50

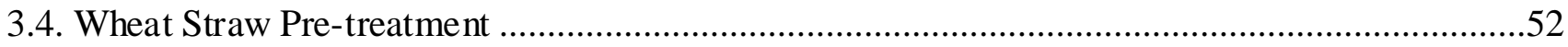

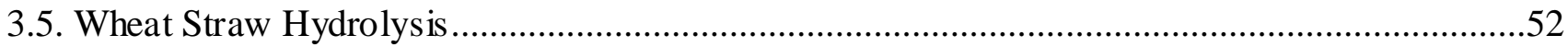

3.6. Simultaneous Saccharification and Fermentation Experiments ...............................................53

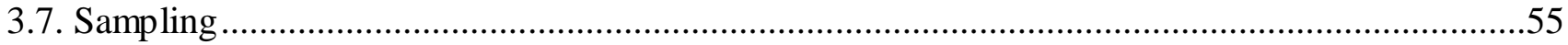

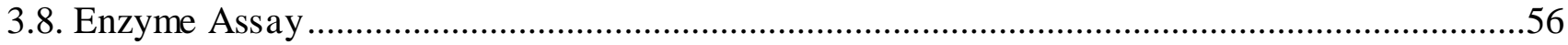

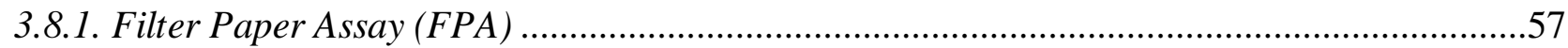




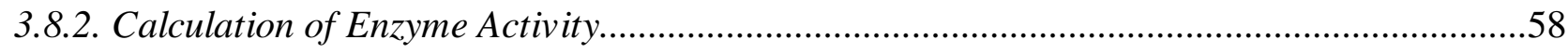

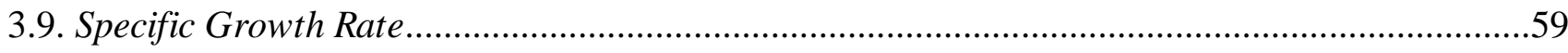

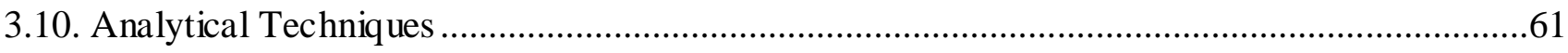

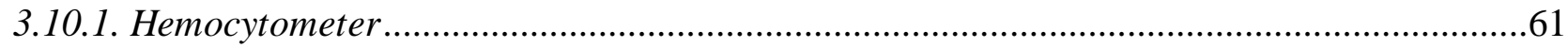

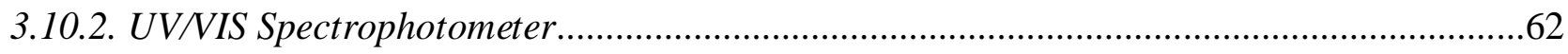

3.10.3. High Performance Liquid Chromatography (HPLC) ...................................................62

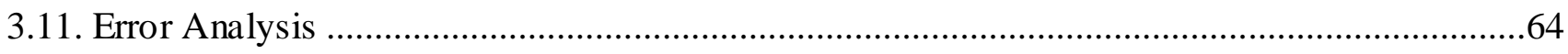

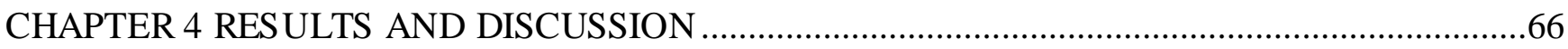

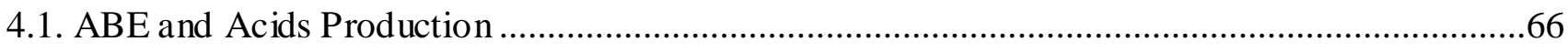

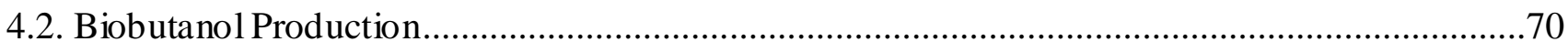

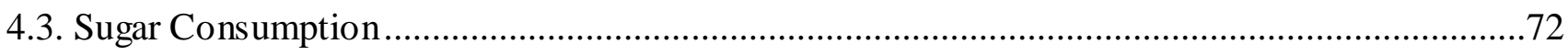

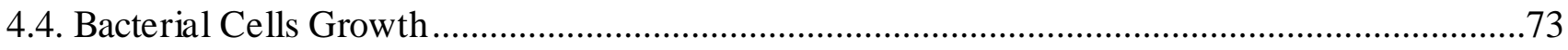

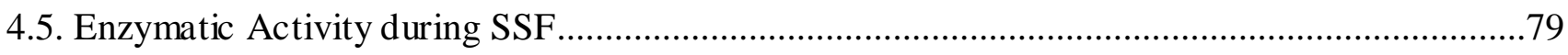

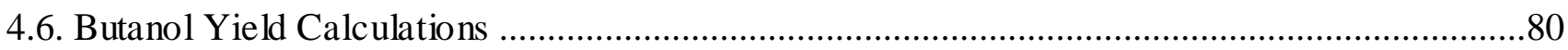

CHAPTER 5 CONCLUSIONS AND RECOMMENDATIONS .................................................84

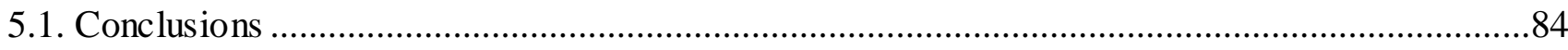

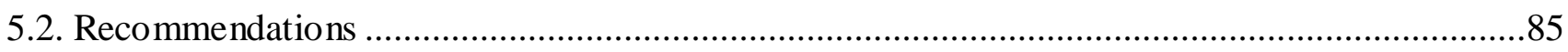

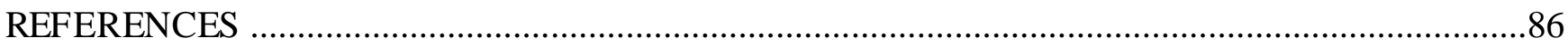

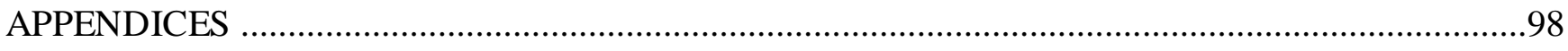

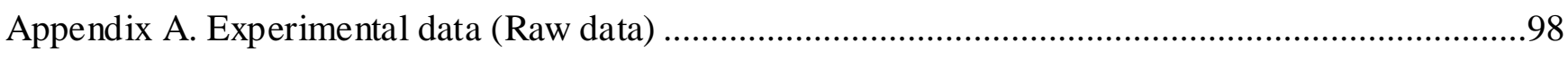

Appendix B. Sugars, ABE, and Acids Standards (HPLC) .......................................................105

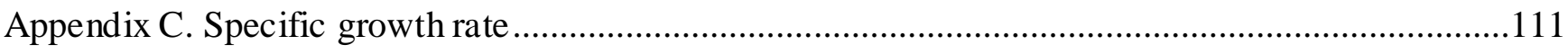

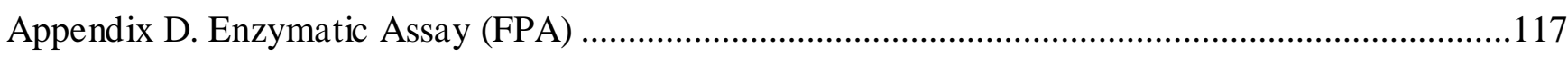




\section{LIST OF TABLES}

Table 1.1. Properties of common fuels with respect to gasoline ...................................................14

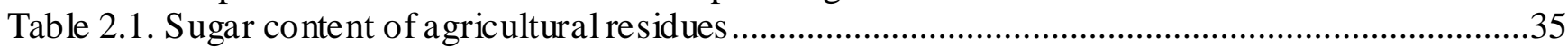

Table 2.2. Comparison of properties of most used agriculture residues for butanol production .............37

Table 2.3. A brief summary of $A B$ production in bioreactors coupled with various product recovery

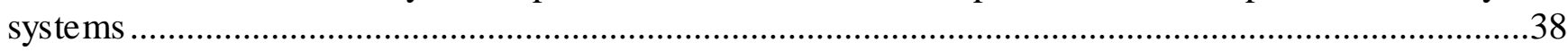

Table 2.4. Cellulase Assays (Adapted from Mandels et al. [98]) .....................................................44

Table 3.1. List of chemicals and enzymes applied in the current study ........................................46

Table 3.2. Clostridium wild and fused strains used in the study course of Batch SSF ........................47

Table 3.3. Compositions of different media used throughout protoplast fusion ..................................48

Table 3.4. Wheat straw hydrolysate sugars at two different temperature ...........................................53

Table 4.1. Production of ABE and acids by Clostridium wild and its fusants during the batch SSF

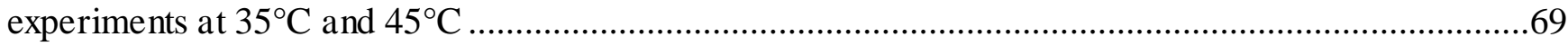

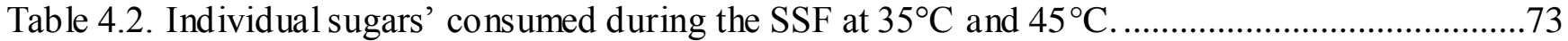

Table 4.3. Kinetic parameters for Clostridium species and its fused strains in batch fermentation at

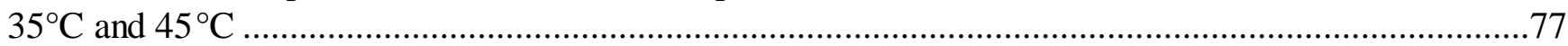

Table 4.4. Enzyme activity of clostridial fused strains in SSF ......................................................80

Table 4.5. Biobutanol yields of Clostridium species and its fused strains at $35^{\circ} \mathrm{C}$ and $45^{\circ} \mathrm{C} \ldots \ldots \ldots \ldots . . . .81$

Table 4.6. Comparison of current research results with the other research works ..............................83

Table A.1. Production of ABE and acids by clostridium species and its fusants at $35^{\circ} \mathrm{C}$.....................98

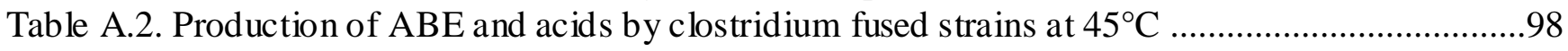

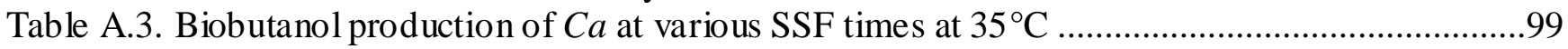

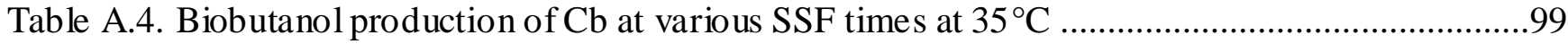

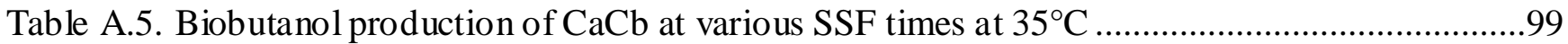

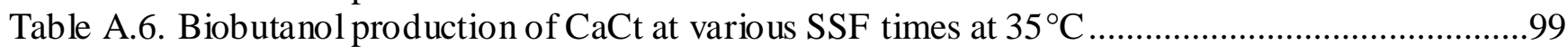

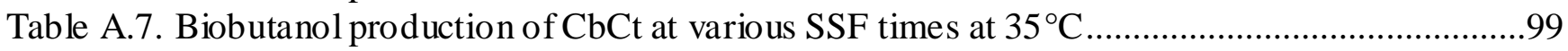

A.8. Biobutanol production of $\mathrm{CaCt}$ (without enzyme) at various SSF times at $35^{\circ} \mathrm{C} \ldots \ldots \ldots \ldots \ldots \ldots . . . . . . . . .100$

Table A.9. Biobutanol production of $\mathrm{CbCt}$ (without enzyme) at various $\mathrm{SSF}$ times at $35^{\circ} \mathrm{C} \ldots \ldots \ldots \ldots . . . .100$

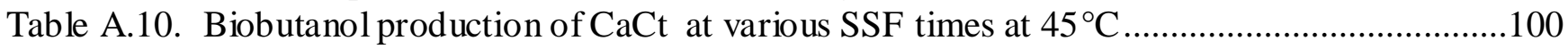

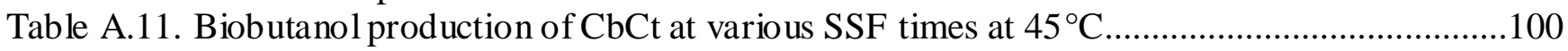

Table A.12. Biobutanol production of $\mathrm{CaCt}$ (without enzyme) at various SSF times at $45^{\circ} \mathrm{C} \ldots . . . . . . . . .100$

Table A.13. Biobutanol production of $\mathrm{CbCt}$ (without enzyme) at various SSF times at $45^{\circ} \mathrm{C}$.............101

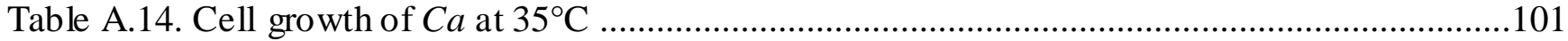

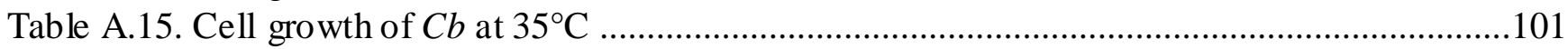

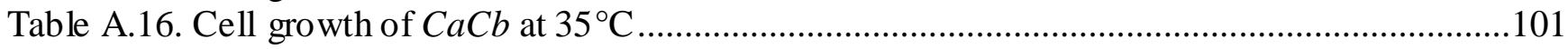

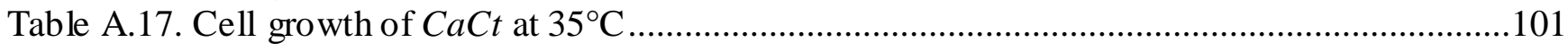

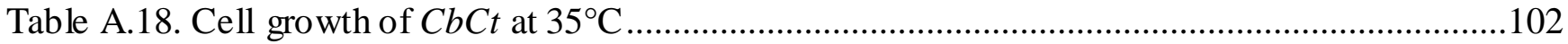

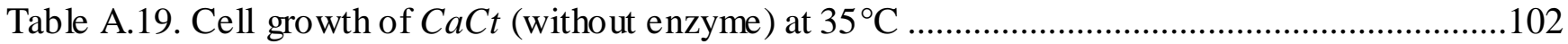

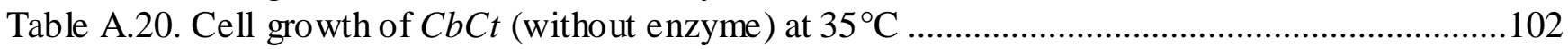

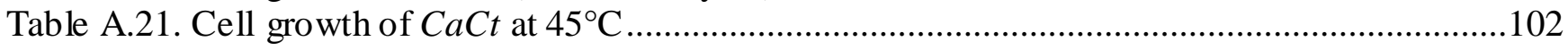

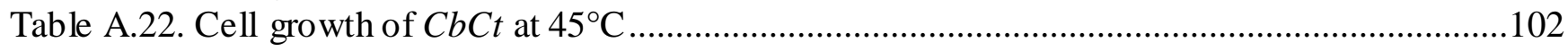

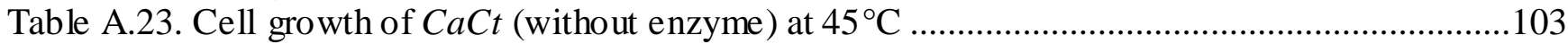

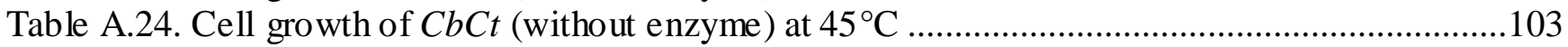


Table A.25. Dry mass of clostridium species and its fused strains to calculate Specific growth rate at

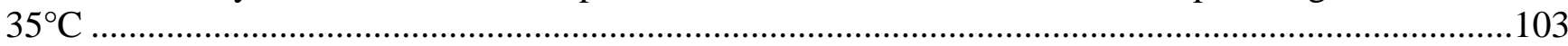

Table A.26. Dry mass of clostridium fused strains to calculate specific growth rate at $45^{\circ} \mathrm{C} \ldots \ldots \ldots \ldots . . .103$

Table A.27. Dilution of glucose stand ards and UV/VIS spectrophotometer reading ........................103

Table A.28. Enzyme dilutions made in sodium citrate buffer of $0.05 \mathrm{M}, \mathrm{pH} 4.8$...........................103

Table A.29. Glucose concentration of samples as determined from standard curve $\left(35^{\circ} \mathrm{C}\right)$................104

Table A.30. Glucose concentration of samples as determined from standard curve $\left(45^{\circ} \mathrm{C}\right)$................104 


\section{LIST OF FIGURES}

Page

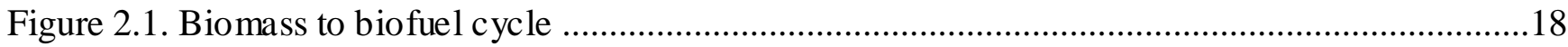

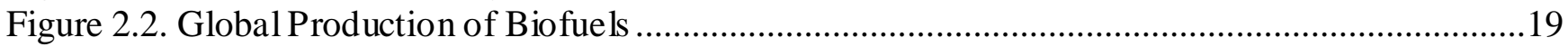

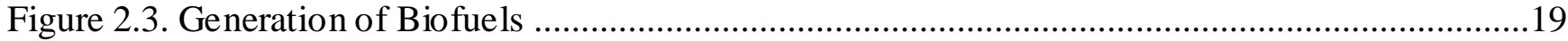

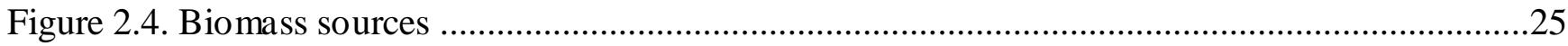

Figure 2.5. Complete molecular structure of biomass containing all three main components. The cellulose is shown in orange, the hemicellulose in blue, and the lignin in green ....................................26

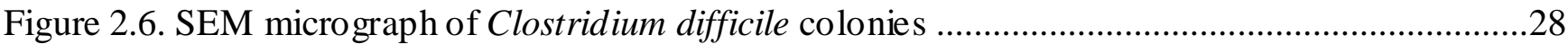

Figure 2.7. Phases of the $\mathrm{ABE}$ fermentation processes showing interactions of fermentation

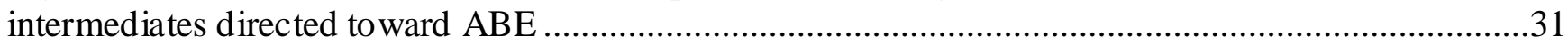

Figure 2.8. Metabolic pathway of acetone-butanol-isopropanol ethanol fermentation ..............................32

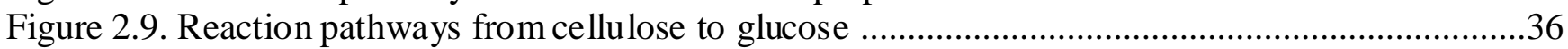

Figure 2.10. (a) Clostridium beijerinckii B-592 growing on BLM medium. (b) L-colonies of $C$.

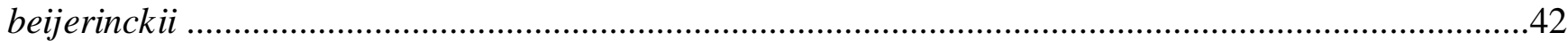

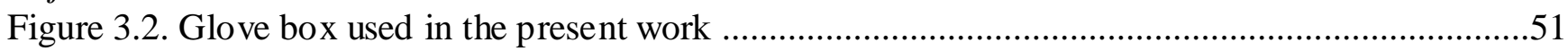

Figure 3.3. Hammer mill that was used to prepare wheat straws .........................................................52

Figure 3.4. Procedure for anaerobic batch simultaneous saccharification and fermentation of biobutanol

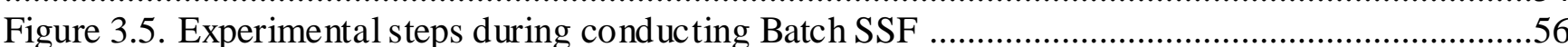

Figure 3.6. Cell growth of fused strain $\mathrm{CaCt}$ at $35^{\circ} \mathrm{C}$ : (a) Dry cell mass over fermentation time; (b)

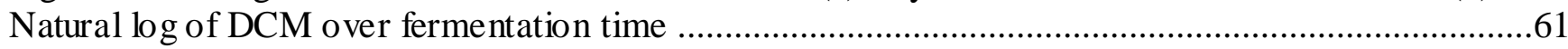

Figure 3.7. GENES YS 10S UV-VIS Spectrophotometer (ThermoFisher Scientific, USA) ...................62

Figure 3.8 HPLC (Perklin Elmer) supplied with Refractive index (RI; model: HP 1047A; Hewlett Packard).

Figure 4.1. Production of $\mathrm{ABE}$ and total acids by Clostridium species and its fusants at $35^{\circ} \mathrm{C}$ (Average error percent of $\mathrm{ABE}$ and Total acids were found by $1.64 \%$ and $8.33 \%$ respectively; Table A.1) ........66 Figure 4.2. Production of $\mathrm{ABE}$ and acids by Clostridium species and its fusants at $45^{\circ} \mathrm{C}$ (Average error percent of $\mathrm{ABE}$ and Total acids were found by $1.26 \%$ and $12.38 \%$ respectively; Table A.1) ................68 Figure 4.3. Biobutanol production in the batch process using Clostridium species and its fused strains at

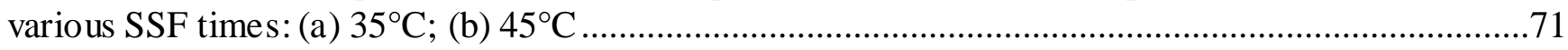
Figure 4.4. Cell growth of Clostridium species during the batch simultaneous saccharification and

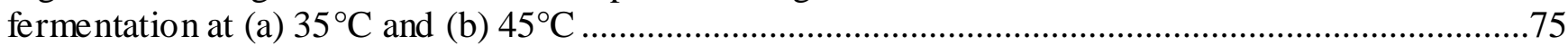

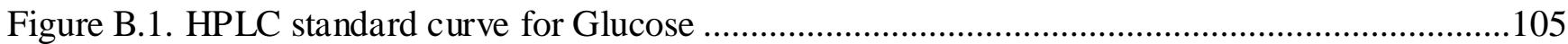

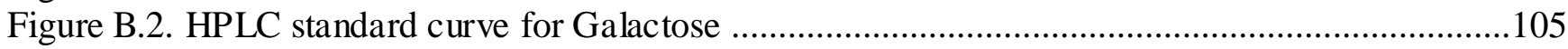

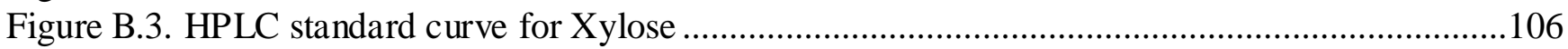

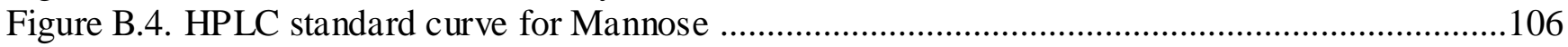

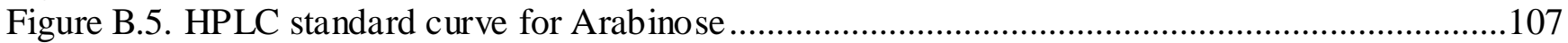

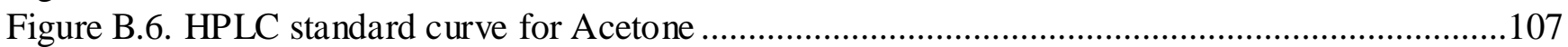

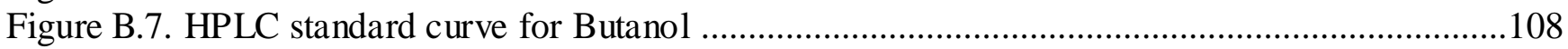

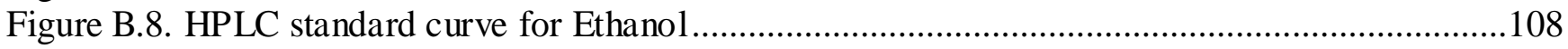

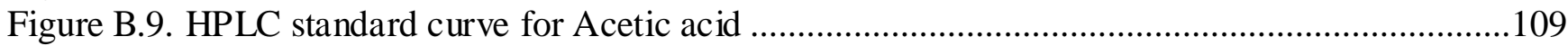

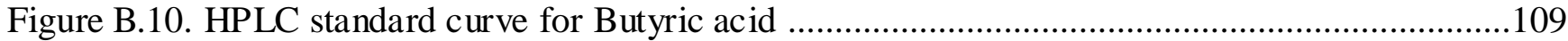

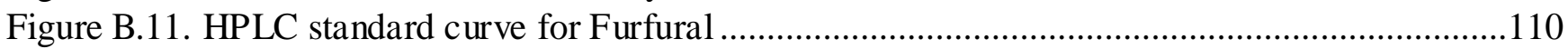

Figure C.1. Growth curve of $\mathrm{Ca}$ at $35^{\circ} \mathrm{C}$ for specific growth rate calculation ....................................111

Figure C.2. Gro wth curve of $\mathrm{Cb}$ at $35^{\circ} \mathrm{C}$ for specific growth rate calculation ....................................111 
Figure C.3. Growth curve of $\mathrm{CaCb}$ at $35^{\circ} \mathrm{C}$ for specific growth rate calculation 112

Figure C.4. Growth curve of $\mathrm{CaCt}$ at $35^{\circ} \mathrm{C}$ for specific growth rate calculation

Figure C.5. Growth curve of $\mathrm{CbCt}$ at $35^{\circ} \mathrm{C}$ for specific growth rate calculation

Figure C.6. Growth curve of $\mathrm{CaCt}$ (without enzyme) at $35^{\circ} \mathrm{C}$ for specific growth rate calculation .....113

Figure C.7. Growth curve of $\mathrm{CbCt}$ (without enzyme) at $35^{\circ} \mathrm{C}$ for specific grow th rate calculation .....114

Figure C.8. Growth curve of $\mathrm{CaCt}$ at $45^{\circ} \mathrm{C}$ for specific growth rate calculation ..............................114

Figure C.9. Growth curve of $\mathrm{CbCt}$ at $45^{\circ} \mathrm{C}$ for specific growth rate calculation ...............................115

Figure C.10. Growth curve of $\mathrm{CaCt}$ (without enzyme) at $45^{\circ} \mathrm{C}$ for specific growth rate calculation ...115

Figure C.11. Growth curve of $C b C t$ (without enzyme) at $45^{\circ} \mathrm{C}$ for specific growth rate calculation ...116

Figure D.1. Glucose standard curve for FPA assay

Figure D.2. Enzyme dilution concentration vs. Glucose concentration for $\mathrm{CaCt} @ 35^{\circ} \mathrm{C}$

Figure D.3. Enzyme dilution concentration vs. Glucose concentration for $C b C t @ 35^{\circ} \mathrm{C}$

Figure D.4. Enzyme dilution concentration vs. Glucose concentration for $C a C t$ (without enzyme) @

$35^{\circ} \mathrm{C}$

Figure D.5. Enzyme dilution concentration vs. Glucose concentration for $C b C t$ (without enzyme) @ $35^{\circ} \mathrm{C}$

Figure D.6. Enzyme dilution concentration vs. Glucose concentration for $\mathrm{CaCt} @ 45^{\circ} \mathrm{C}$

Figure D.7. Enzyme dilution concentration vs. Glucose concentration for $C b C t @ 45^{\circ} \mathrm{C}$

Figure D.8. Enzyme dilution concentration vs. Glucose concentration for $\mathrm{CaCt}$ (without enzyme) @ $45^{\circ} \mathrm{C}$

Figure D.9. Enzyme dilution concentration vs. Glucose concentration for $C b C t$ (without enzyme) @ 


\section{CHAPTER 1}

\section{INTRODUCTION}

Reductions of fossil fuels and fluctuating prices have revived an interest in the development of renewable fuels such as ethanol and butanol. However, acetone-butanol-ethanol (ABE) fermentation process had lost competitiveness by 1960s owing to the increase of feeds tock costs and advancement of the petrochemical industry. In contrast, some countries such as South Africa and Russia ABE fermentation process remained competitive due to the low costs of the substrate and the labour [1]. In the first generation of biofuels, production is achieved by the action of microorganisms and enzymes through the fermentation of starch or cellulose. This method although useful, is not able to achieve high production of biofuel without threatening food supplies and biodiversity. On the other hand, the second generation of biofuels, which is derived from lignocellulosic crops, can be produced sustainably from biomass consisting of the residual non-food parts of current crops or agricultural residues. Lastly, third generation of biofuel is made from algae. High oil prices, competing demands between foods and other biofuel sources, and the world food crisis, have ignited interest in algae culture (farming algae) for producing biofuels, using land that is unsuitable for agriculture. These all lead to the interest in the Consolidated Bioprocessing (CBP), which is an alternative processing strategy, where feedstock substrate hydrolysis and biofuel production by fermentation are accomplished in a single process step simultaneously by microorganisms that produce cellulolytic enzymes.

The ABE fermentation processes in South Africa and Russia continued to operate until the late 1980s to early 1990s [2]. It has recently been claimed that the Russian fermentation industry is 
focusing on the conversion of agricultural biomass into butanol. The rapid rise in petrochemical prices and increased dependence on foreign fuel brought about to a renewed interest in the feasibility of obtaining fuels or chemically feed stocks by microbial conversion. However, special attention was paid to the ABE fermentation. USA has instigated various energy initiatives, including replacing $30 \%$ of transportation fuel by ethanol by 2030 [3]. Besides, attempts are underway to accumulate other alternative fuels and chemical feedstock from the renewable resources such as butanol. Reflecting this, a number of companies are working continuously to improve biobutanol production processes. In 2006, BP and DuPont announced a joint effort to establish a biobutanol production facility based on the fermentation process. BP has also created a subsidiary called BP Biofuels to commercialize butanol from this fermentation process.

Renewable resources are described as those that can be used without depletion, include solar and wind energy, hydro power and biomass. Fermentation processes have a good potential for significantly contributing toward a more sustainable world; because of the biomass used by a number of microorganisms for the production of interesting chemicals and energy carriers such as solvents acetone, butanol and ethanol [4]. In addition to the development of superior microbial strains and novel process technology, substrate cost plays an important role in the commercial production of butanol [5]. Consequently, it has been identified that wheat straw (WS) could be a successful industrial substrate for butanol production [6, 7]. According to the Food and Agriculture Organization of the United Nations, approximately $616 \times 10^{6}$ tones of WS was produced worldwide in 2006 , including $51.0 \times 10^{6}$ tones in the US alone [8]. WS is composed of cellulose, hemicellulose, and relatively low lignin content; this lignin content makes bioconversion to biofuel particularly noticeable. Therefore, the use of WS as a potential substrate has been increasingly studied for various bioconversion processes [9]. In the current study, WS has been used as a substrate for biobutanol production. 
Biobutanol is a biofuel that can be produced from renewable resources using special strains of bacteria such as Clostridium acetobutylicum or Clostridium beijerinckii [7]. The advantage of using these strains is that they can utilize both lignocellulosic hydrolysate sugars (hexoses and pentoses) in contrast to traditional ethanol-producing yeast strains that cannot do that [10]. As a biofuel, butanol has some interesting properties that other fermentation derived fuels do not have. Butanol can replace gasoline as a fuel, even to a larger extent than ethanol, due to its physical properties, cost-effectiveness and safety. Butanol is a cleaner and superior fuel extender than ethanol [11, 12]; it contains $22 \%$ oxygen making it an excellent fuel extender; it is more hydrophobic than ethanol and mixes better with hydrocarbon fuels. The lower vapour pressure makes it suitable for use as an oxygenate and facilitates its application in existing gasoline supply channels. Butanol also has a higher heating value than ethanol; this allows it to be used as a replacement for gasoline without engine modifications [13]. Butanol's energy content is $30 \%$ more than ethanol and is closer to gasoline. In addition to that it is not sensitive to water, is less volatile, low hazardous to handle, little flammable, and can be mixed with gasoline in any proportion $[14,15]$.

Table 1.1 displays the properties of common fuels with respect to gasoline; where the octane number of a fuel is a measure of its resistance to knocking, fuels with octane ratings of more than 100 are actually used in racing car and in the world of aviation. In Europe, the octane number posted is determined by the research octane number $(\mathrm{RON})$ method whereas in the USA, the number posted is according to the $(R O N+M O N) / 2$ method, where MON stands for motor octane number (Table 0.1). It is obvious, that the MON is lower than the RON, given the fact that the test engine is run under a higher load. Thus, higher compression ratio and temperature would logically result in a higher sensitivity to knocking. With such superior fuel properties and recent advances in biotechnology and bioprocessing (development of superior strains and advanced process technology), commercial interest has returned to butanol fermentation [16]. 
Table 0.1. Properties of common fuels with respect to gasoline (Adapted from Sang et al. [17])

\begin{tabular}{|l|l|l|l|l|}
\hline Fuel Property & Gasoline & Butanol & Ethanol & Methanol \\
\hline Energy density (MJ/L) & & & & \\
\hline Air-Fuel ratio & 32.00 & 29.20 & 19.60 & 16.00 \\
\hline Specific energy (MJ/kg air) & 14.60 & 11.20 & 9.00 & 6.50 \\
\hline Heat of vaporization (MJ/kg) & 2.90 & 3.20 & 3.00 & 3.10 \\
\hline Research Octane Number (RON) & 0.36 & 0.43 & 0.92 & 1.20 \\
\hline Motor Octane Number (MON) & $91-99$ & $96-105$ & 129 & 136 \\
\hline
\end{tabular}

Economically viable feed stocks (i.e., renewable resources such as WS, rice straw, switch grass, etc.) have been considered widely in biofuel production. Undesirably, neither commercial ethanolproducing cultures nor butanol-producing cultures can hydrolyze these substrates without using a combination of appropriate pre-treatment and hydrolysis techniques prior to fermentation (i.e., acid, alkali, or ammonia explosion) $[10,18]$. The thermophilic cellulolytic anaerobe Clostridium thermocellum is potentially an important industrial organism for the conversion of cellulosic biomass to liquid fuel, which prompted studies on the physiology and genetics of the organism [19]. Cellulolytic and solventogenic species such as $C$. thermocellum, C. saccharobutylicum, C. cellulolyticum, and $C$. acetobutylicum are some of the best-studied biomass-metabolizing bacteria, with significant potential for sustainable biofuel production via consolidated bioprocessing [20]. Thermostable Clostridium species were developed through protoplast fusion between mesophilic and thermophilic Clostridial species. The challenge facing the enzymatic hydrolysis during the simultaneous saccharification and fermentation is the lower temperature of fermentation (nearly $35^{\circ} \mathrm{C}$ ) while optimum temperature of enzymatic hydrolysis was proven to be at $45^{\circ} \mathrm{C}$ temperature [7]. In this case, the lower efficiency of enzyme at $35^{\circ} \mathrm{C}$, especially cellulase, increases the cost of fermentation and prolongs butanol production cycle [21]. In the current study, a novel solution for this challenge was introduced through which biobutanol was produced at higher production and yield in batch SSF from WS. Several bacterial 
strains were examined that includes, with the fusants CaCt (Clostridium acetobutylicum Clostridium thermocellum) and $\mathrm{CbCt}$ (Clostridium beijerinckii Clostridium thermocellum) that were examined at $45^{\circ} \mathrm{C}$. These fused strains were formed through protoplast fusion between mesophilic (C. acetobutylicum and $C$. beijirinckii) and thermophilic Clostridial species (i.e., Clostridium thermocellum).

However, in this study, protoplast fusion strains of $\mathrm{CaCt}$ and $\mathrm{CbCt}$ produced enzymes to hydrolyze WS. These are endo- acting cellulases that cleave at internal sites on the cellulose chain, exoacting cellulases which cleave fragments from the ends of the cellulose chain, and $\beta$-glucosidases to hydrolyze soluble fragments to glucose. Furthermore, $45^{\circ} \mathrm{C}$ temperature was used for SSF because at this high temperature, the fused strains grew more frequently than at $35^{\circ} \mathrm{C}$ resulting sufficient amount of biobutanol production that is quite outstanding. Use of dilute sulphuric acid is advantageous in the hydrolysis of cellulosic biomass as it hydrolyzes much of the hemicellulose to pentose sugars. The residual cellulose and hemicellulose was hydrolyzed by enzymes produced from fusants. Application of alkali solubilizes hemicellulose but does not hydrolyze it [22].

Significantly, the Clostridia are not able to efficiently hydrolyze fibre rich agricultural residues. For this reason, agricultural biomass must be hydrolyzed to simple sugars using economically developed methods. Dilute sulphuric acid pre-treatment can be applied to agricultural residues to bring about hydrolysis. Unfortunately, during acid hydrolysis, a complex mixture of microbial inhibitors is generated [23]. It is possible that generation of these inhibitors is substrate specific. Furfural and hydroxymethyl furfural (HMF) are not inhibitory to $C$. beijerinckii BA101. They have stimulatory effect on the growth of the microorganism and ABE production. [24].

In the current study, production of biobutanol was examined using Clostridium strains and their protoplast fusants; thus, it might be easier to compare and select the best strain which is responsible for 
higher yield of biobutanol, whereas substrate basis was taken from that of Qureshi et al [7]. Fermentation by these microorganisms is biphasic-involving acidogenesis, the production of acids (acetic and butyric acids), followed by solventogenesis, which is the production of solvents (ABE in a 3:6:1 ratio) from the previously produced acids during fermentation [25]. 


\section{CHAPTER 2}

\section{LITERATURE REVIEW}

\subsection{Biofuel}

With world energy consumption predicted to increase 54\% between 2001 and 2025, primary attention has been directed towards the development of carbon neutral energy and sustainable sources to meet the future needs [26]. Biofuels are an attractive substitute to current petroleum based fuels because they can be utilized as transportation fuels with diminutive change to current technologies; they also have significant potential to improve sustainability and reduce greenhouse gas emissions. Liquid (i.e., ethanol, butanol, biodiesel) or gaseous (i.e., methane or hydrogen) biofuels are generally produced from organic materials such as starch, oilseeds and animal fats, or cellulose, agricultural crops or residues. Figure 2.1 shows biomass to biofuel cycle. Byogy Renewables Inc. stated that the advanced process is possibly only by an integrated system that converts biomass directly to gasoline. However, most of the other emerging processes convert the biomass into alcohol and then blend it with gasoline. Byogy Renewables Inc. concluded that the system is relatively inexpensive and focuses on using biomass waste streams and non-food energy crops rather than food products such as corn. 


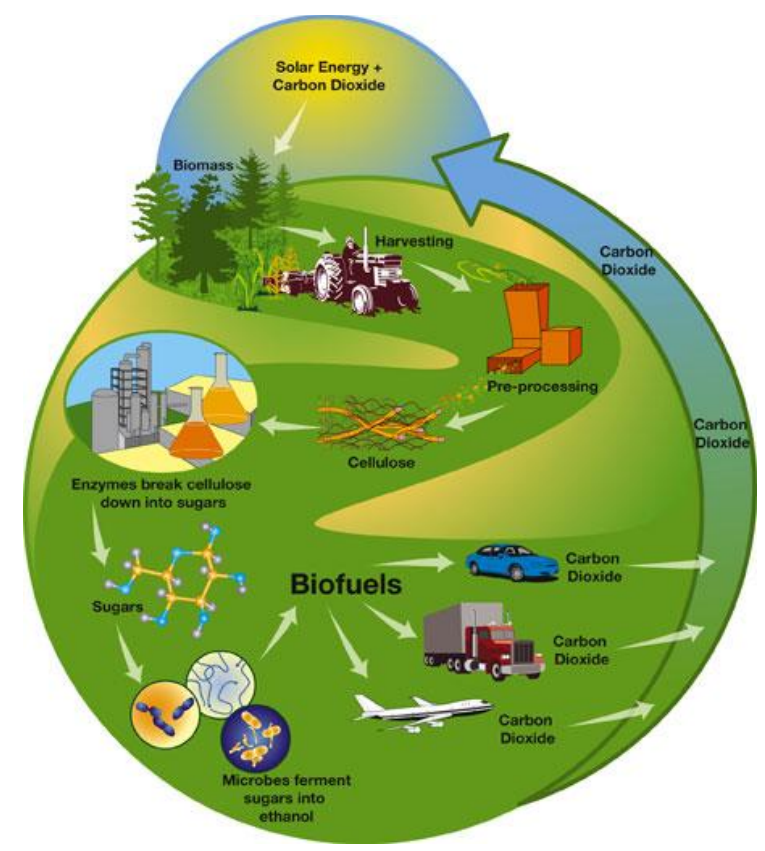

Figure 2.1. Biomass to biofuel cycle

(Adapted from Ed Munro et al. [27])

Cellulose is one of the most abundant biopolymer in the world; they are potential feedstock for the synthesis of biofuels; which could displace fossil fuel consumption and reduce greenhouse gas emissions [28, 29]. Current strategies to produce fuel from cellulose, utilize simultaneous saccharification and fermentation (SSF) or simultaneous saccharification and co-fermentation (SSCF) $[30,31]$. Both SSF and SSCF require extensive pre-treatment of the cellulosic feed stock followed by addition of exogenously produced cellulolytic enzymes to hydrolyze cellulose chains and release the glucose monomers required for fermentation.

Consolidated bioprocessing (CBP) offers the potential for lower biofuel production costs due to simpler feed stock processing; it displays lower energy inputs and higher conversion efficiencies than SSF based processes. Because of the use of renewable fuels is rising, many countries are trying to reduce petroleum imports. This eventually boosts up rural economies, and improves air quality through increased use of biomass. Brazil and the United States lead the world in production of biofuels for transportation, primarily ethanol (Figure 2.2). Several other countries have also developed biofuel programs, including China, India, Canada, Thailand, Argentina, Australia, and Colombia. 


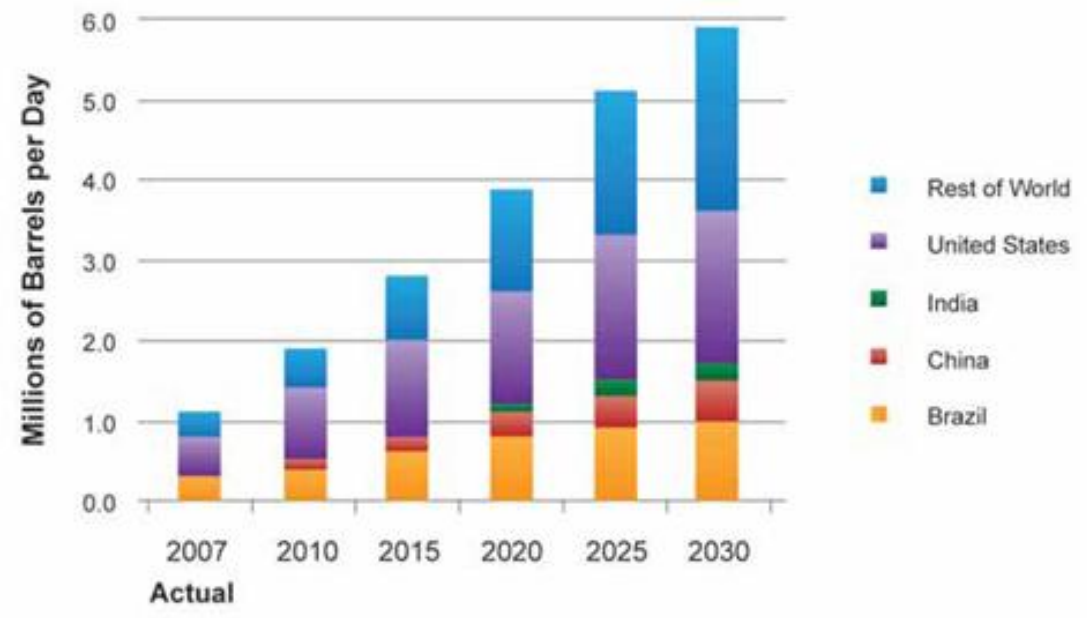

Figure 2.2. Global Production of Biofuels

(Adapted from Technol ogy Roadmap, [32])

\subsection{Generation of Biofuel}

Biofuels can be divided into three generations; 1 st generation biofuels, 2 nd generation biofuels and 3rd generation biofuels as shown in Figure 2.3.

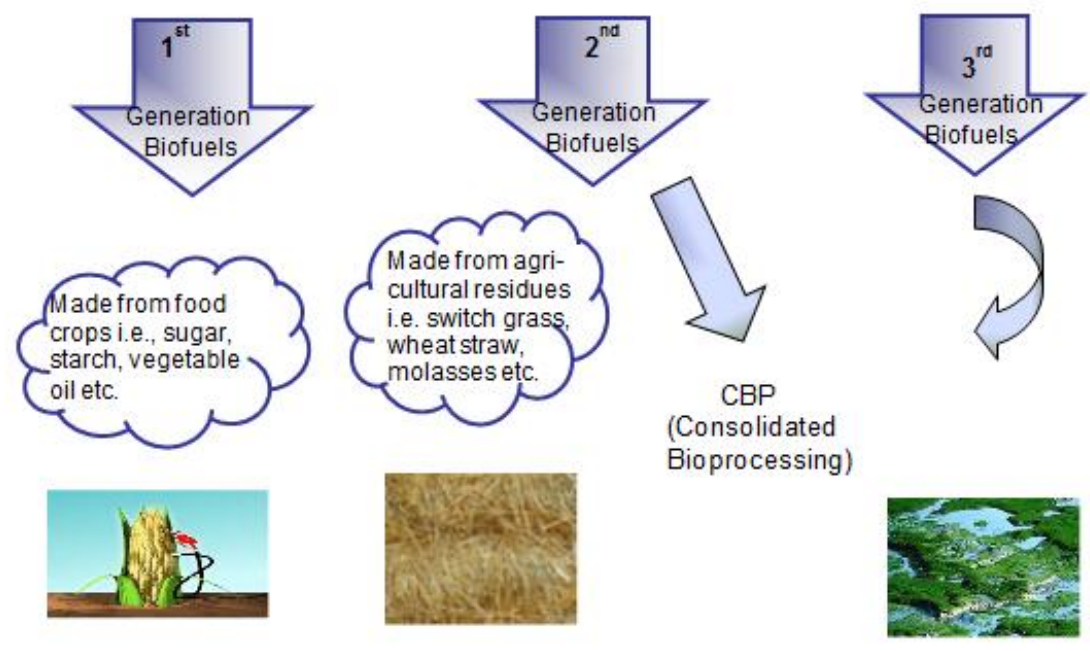

Figure 2.3. Generation of Biofuels 
First generation biofuels are made from sugar, starch, and vegetable oil. Biologically produced fuels such as ethanol, propanol, and butanol are produced by the action of microorganisms and enzymes through the fermentation of sugars or starches, or cellulose. First generation biofuel processes are useful but there is a threshold above which they cannot produce enough biofuel without threatening food supplies and biodiversity. Many first generation biofuels are dependent of subsidies and are not cost competitive with existing fossil fuels such as oil, and some of them produce only limited greenhouse gas emissions savings. Taking into account emissions from production and transport, life cycle assessment from first-generation biofuels frequently exceed those of traditional fossil fuels [33].

Second generation biofuels are derived from lignocellulosic crops. This generation technology allows lignin and cellulose of a plant to be spitted so that cellulose can be fermented into alcohol. These biofuels can be manufactured from different types of biomass as it defines any source of organic carbon. This can be renewed rapidly as part of the carbon cycle. Second generation biofuel technologies have been developed because first generation biofuels manufacture has important limitations [34]. Second generation biofuels can solve these problems and can supply a larger proportion of biofuel sustainably and affordably with greater environmental benefits. The goal of second generation biofuel processes is to extend the amount of biofuel that can be produced sustainably by using biomass. Specially biomass which is the residual non-food parts of current crops, such as stems, leaves and husks that are left behind once the food crop has been extracted. And also other kind of crops that are not used for food purposes, such as switch grass, wheat straw, cereals etc. that bear little grain [35]. A lot of venture funding is going into second-generation biofuels start-ups, companies are competing to develop a single, cost-effective process for producing biofuels. $K i O R$, Inc. is working on their "biomass catalytic cracking process". Meanwhile, Coskata, Inc. states that they are able to produce ethanol for $\$ 1$ a gallon using old tires as feedstock. Mascoma Corporation is working to build 
a "super bug" that would digest lignocellulosic feedstock while ZeaChem Inc. is trying to use poplar trees for fuel.

Third generation biofuel, is a biofuel produced from algae; which are low-input, high-yield feedstock to produce biofuels. Based on laboratory experiments, it is claimed that algae can produce up to 30 times more energy per acre than land crops such as soybeans [36] but still not produced commercially. With the higher prices of fossil fuels (petroleum), there is much interest in algae culture (farming algae). One advantage of many biofuels over most other fuel types is that they are biodegradable, and so relatively harmless to the environment if spilled [37]. Algae fuel still has its difficulties, for instance to produce algae fuels it must be mixed uniformly, which, if done by agitation, could affect biomass growth [38]. Several companies and government agencies are funding efforts to reduce capital and operating costs and make algae fuel production commercially viable [39].

High oil prices, competing demands between foods and other biofuel sources, and the world food crisis, have ignited interest in alga culture (farming algae) for producing biofuels, using lands that are not suitable for agriculture. Algae cost more per unit mass; for instance, as of 2010, food grade algae costs approximately $\$ 5000 /$ tonne because of its high capital and operating costs [40]. Greenwell et al. showed that algae displays theoretically yield between 10 and 100 times more energy per unit area than other second-generation biofuel crops [41]. The United States Department of Energy estimates that if algae fuel replaced all the petroleum fuel in the United States, it would require 15,000 square miles which is only $0.42 \%$ of the U.S. map $\left(40,000 \mathrm{~km}^{2}\right)$ [42].

Consolidated bioprocessing (CBP) is an alternative processing strategy in which cellulose production, substrate hydrolysis, and fermentation are accomplished in a single process step by microorganisms that express cellulolytic and hemicellulolytic enzymes [30, 31]. Demain et al. 
suggested that CBP is an economically attractive near-term goal process for biofuel production [27]. Successful development of this generation biofuels depends heavily on a detailed understanding of the metabolism of cellulolytic bacteria.

\subsection{History of Butanol}

Biobutanol production through anaerobic bacteria fermentation has been observed since 1861, witnessed by Pasteur. During anaerobic bacteria fermentation processes, butanol is a single product among many. By the beginning of the 20th century, interest in butanol had risen sharply. A shortage of natural rubber had thrashed society and efforts were undertaken to make a synthetic rubber. It was found that butadiene or isoprene rubber could be synthesized from butanol or isoamyl alcohol. This discovery stimulated great interests in anaerobic fermentative processes for compound production.

Fermentation processes began to experience a decline after the end of World War 2. During 1960, petrochemical production of solvents became much easier and cheaper, whereas farmer interests in molasses caused molasses prices to increase dramatically. The combination of these events made fermentative production of acetone and butanol inefficient and not economical. In the middle of the $20^{\text {th }}$ century, biobutanol was made of corn or molasses by fermentation involving Clostridium acetobutylicum. The final products consisted of acetone, butanol and ethanol and the process was referred to as $\mathrm{ABE}$. By-products of $\mathrm{ABE}$ fermentation include hydrogen; isopropanol; acetic, lactic, propionic and butyric acids; carbon dioxide; and lipids. The need to separate the main fermentation products and to remove by-products is causing an increase of the production cost of each liter of butanol. ABE fermentation using bacteria Clostridium acetobutylicum is one of the pioneering processes used for industrial butanol fermentation. Based on the application of the above anaerobic microorganisms, such industry as microbiological production was established. However, prior to the 
introduction of a new strain called Clostridium beijerinckii and the development of a novel technology by Environmental Energy Company, fermentation was a complicated and hardly controllable process.

At the beginning of $21^{\text {st }}$ century, Hans Blaschek, a Professor of the Food Microbiology Department of the University of Illinois in the U.S., isolated a new Clostridium strain. In 2004, Clostridium beijerinckii was selected by the U.S. Department of Energy for gene mapping. Using a genetically modified microorganism, Clostridium beijerinckii, patented Dr. Blaschek, it was possible to transformed corn into butanol. Professor Blaschek has developed fundamentals of butanol production technology through its extraction from gas. In this case, butanol will be inexpensive and contain no impurities, which could be found in the product if membrane-based technologies are used. In 2006, BP and DuPont announced their joint efforts in the production of advanced biofuel, putting emphasis on biobutanol. The partnership objective was to develop a process of biobutanol production economically equal to the process of bioethanol production by 2010. In general, BP and DuPont invested about US $\$ 400 \mathrm{M}$ to the construction of a new facility for biofuel process development.

Nasib Qureshi, a Professor of the Department of Food Science and Human Nutrition of the University of Illinois in the U.S. developed a membrane process for more effective butanol production in the fermentation conditions. Though butanol-forming bacteria generate enzymes which convert simple sugars into alcohol, butanol itself is toxic for these microbes. As result of such inhibition by butanol, there is a low alcohol concentration in the fermenting medium. Thus, butanol yield is reducing and production costs are growing. These challenges occur through the use of highly purified raw materials. When less expensive biological raw materials are used, the additional bacterial inhibitors are produced at the stage of preliminary treatment. Strategies are being developed to reduce butanol toxicity and increase its output, including several integrated levels in the process of control of microbiological cultures. 


\subsection{Agricultural Biomass}

All biomass is composed of three major building blocks of any leafy plant: cellulose, hemicellulose and lignin. There is only a small difference in composition among different biomass source; most biomass is composed of roughly $40 \%$ cellulose, $25 \%$ hemi-cellulose and $25 \%$ lignin by mass, with ash and miscellaneous compounds making up the remaining $10 \%$. Figure 2.4 shows biomass sources.

Raw biomass feedstock can be converted to biofuel through multiple processes. Conversion technologies fall into two principal categories: thermo chemical conversion and biological conversion processes. A thermo chemical conversion process is one that makes use of a chemical reaction induced by elevated temperatures and pressures to change the molecular structure of the input. On the other hand, biological conversion employs carefully selected microorganisms to convert biomass into fuel. 


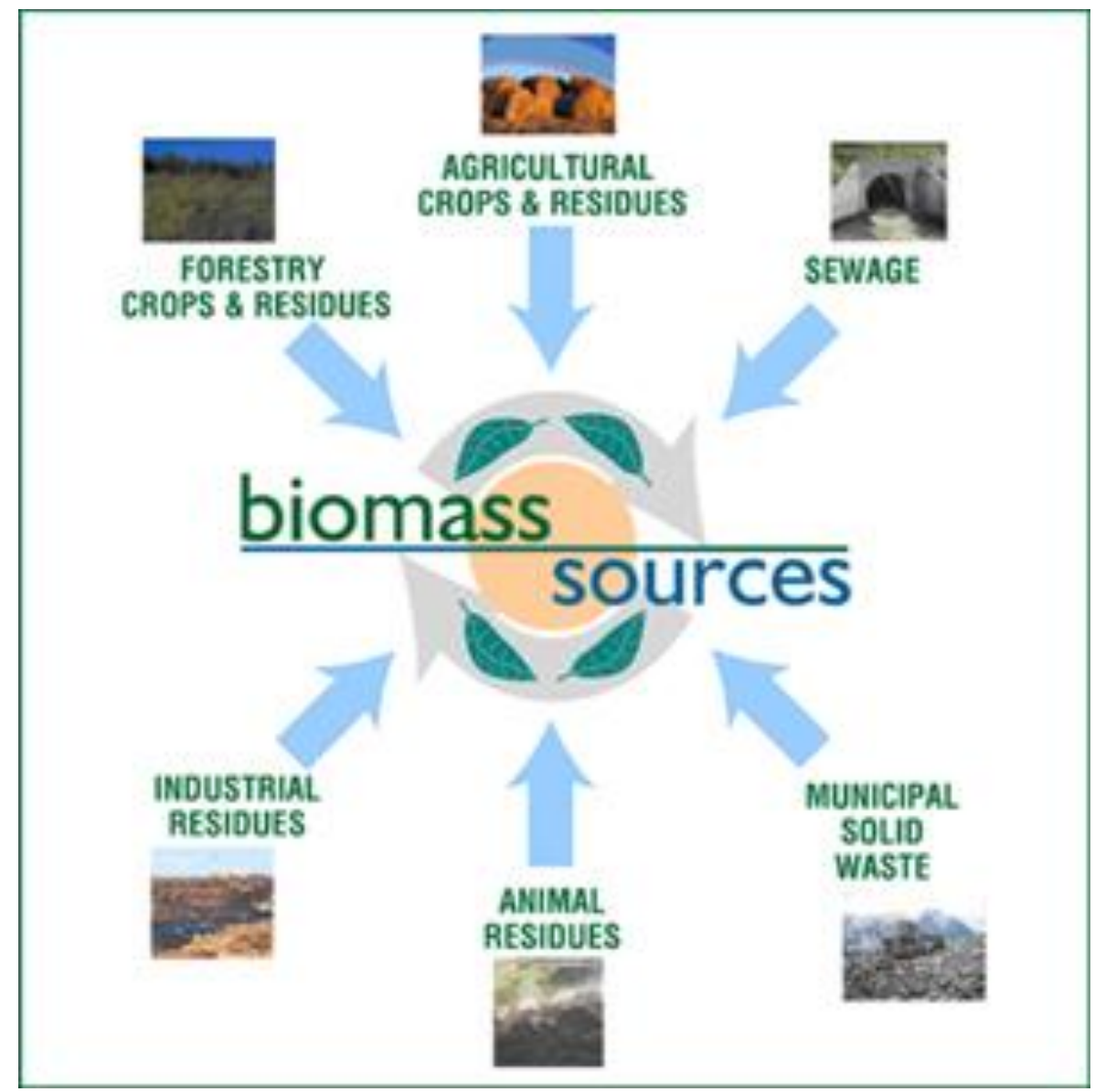

Figure 2.4. Biomass sources

(Adapted from Ed Munro et al. [27])

The non-food fraction of biomass is called lignocellulosic biomass. Other plants, such as switch grass or short-rotation poplar stands, are being considered as potential lignocellulosic biomass feedstock. They would be grown as a source of lignocellulose for conversion into biofuels and would not be accompanied by any food production. Figure 2.5 shows the structure of lingo-cellulosic biomass where the three components of lignocellulosic biomass are intertwined in a complex composite matrix. This creates the strength of the resulting structural components.

Cellulose is a strong, un-branched polymer of glucose sugars that is found in plant cell walls. In Figure 2.5, cellulose fibres are arranged as a woven mat within the biomass. Hemicellulose is also 
found in plant cell walls. Hemicellulose is made up of a highly branched polymer structure of both glucose and other sugars, many of which contain five carbon atoms. In contrast to cellulose, hemicellulose is heavily branched and this makes it structurally weaker. For biological conversion, hemicellu lose is easily hydrolyzed by dilute acid or base as well as a variety of enzymes.

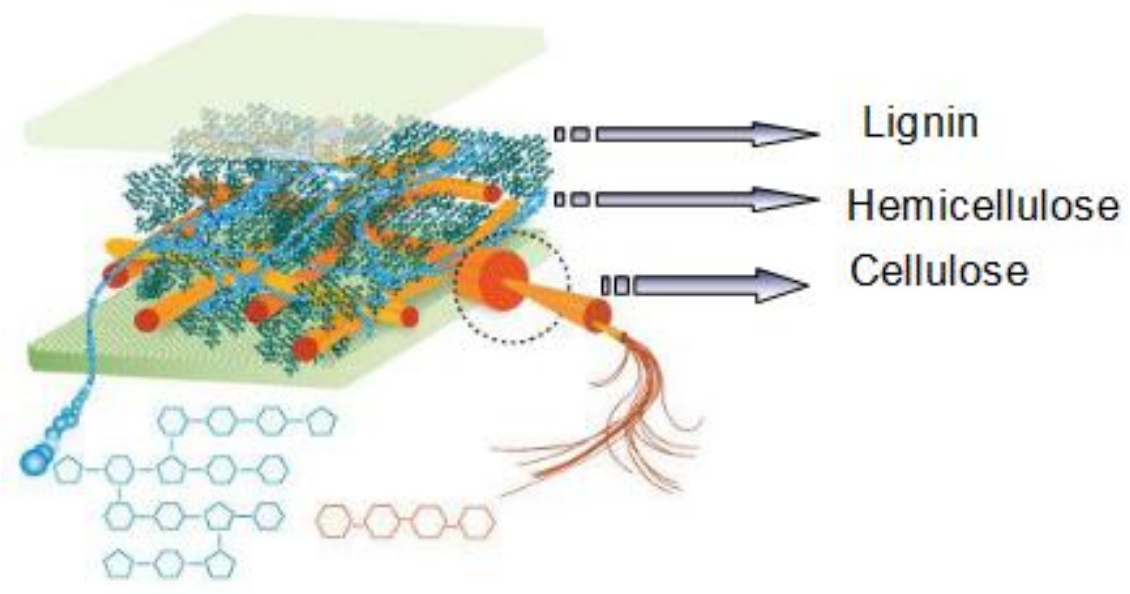

Figure 2.5. Complete molecular structure of biomass containing all three main components. The cellulose is shown in orange, the hemicellulose in blue, and the lignin in green

(Adapted from Ceres biofuels, [43])

On the contrary, lignin occupies the interstitial space of a plant cell wall. It fills the area around the branches and chains of hemicellulose and cellulose (Figure 2.5). It is covalently bonded to hemicellulose which results in the strength of the lignocellulosic matrix, and thus gives the entire resulting plant structure. The biomass should be pre-treated to break down the lignocellulosic matter. The cellulosic fraction is hydrolyzed into glucose sugars, while the hemi-cellulosic fraction is detoxified. The sugars from the cellulose hydrolysis can be fermented into biofuel using yeasts or other microorganisms genetically modified for this purpose. The five-carbon sugars derived from hemicellu lose can also be converted into biofuel using the same microorganism used for the six-carbon sugar fermentation as in the case of Simultaneous Saccharification and Fermentation (SSF) process. 
The conversion energy requirement during processing depends on the level of overall optimization of the sub-processes of the SSF process. Cellulose is composed of both highly amorphous regions containing large voids and other irregularities as well as tightly packed crystalline regions.

Cellulose is generally degraded into $\mathrm{H}_{2} \mathrm{O}$ and $\mathrm{CO}_{2}$ in aerobic systems while in anaerobic systems $\mathrm{CH}_{4}$ and $\mathrm{H}_{2}$ are also produced. Although, most cellulose is degraded in aerobic environments, 5 to $10 \%$ is degraded under anaerobic conditions by a range of physiologically diverse bacteria. Among these cellulolytic bacteria class Clostridia have been best studied and characterized. These bacteria form endospores and digest cellulose through an exocellular enzymatic complex called a cellulosome. They convert cellulose into several different metabolites. The third generation of biochemical conversion of lignocellulosic biomass is focused on developing process where both the biofuel and all enzymes are produced by a single microorganism community using consolidated bioprocessing (CBP).

This will improve the energy cost that is economical cost of enzymes required for biochemical processing of biomass.

\subsection{Clostridia and Ferme ntation Metabolis m of Butanol}

Qureshi et al. [7] illustrated butanol as a fuel that is superior to ethanol. Ennis et al. [44] and Formanek et al. [45] showed that butanol can be produced by a number of organisms belonging to the genus Clostridium like Clostridium acetobutylicum or $C$. beijerinckii, utilizing a number of substrates (Figure 2.6). During experimental work in fermentation: acetone, butanol, and ethanol (ABE) were produced in the ratios 3:6:1, with butanol being the major product. Clostridia are Gram-positive, anaerobic, and rod-shaped but when producing spores they appear more like drumsticks with a bulge at one end, fermenting by the pathways that generate organic solvents such as butanol. 


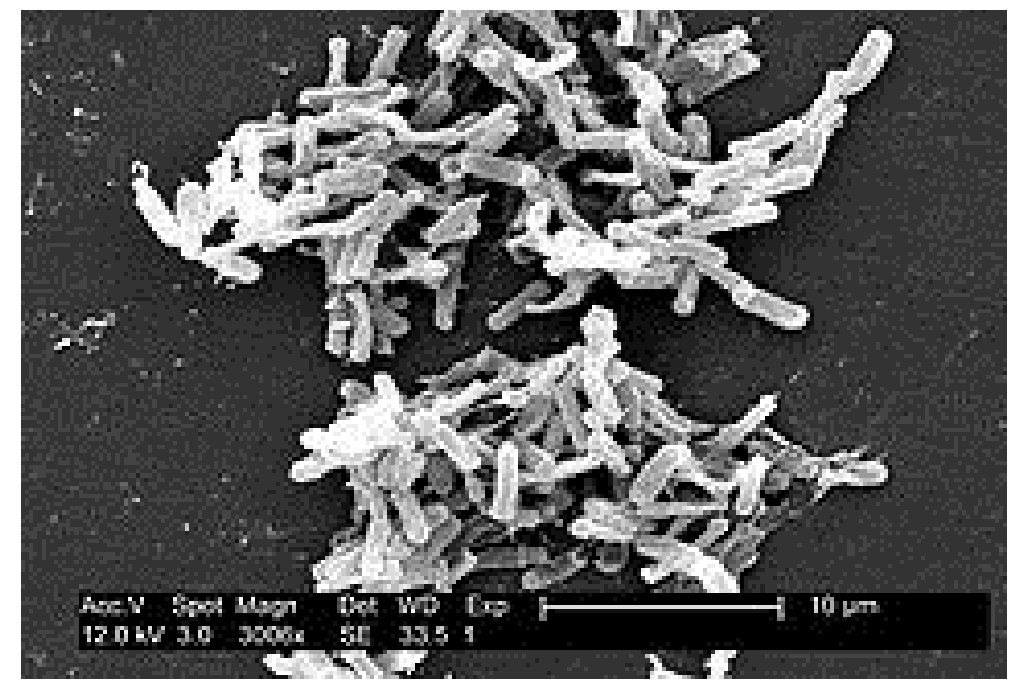

Figure 2.6. SEM micrograph of Clostridium difficile colonies

(Adapted from mashpe di a.com/Clostridium, [46])

Among the clostridia, there are both pathogenic and non-pathogenic species to human and animals. The pathogenic species are generally proteolytic and without exception all species produce toxins, usually enzymes that are responsible for their toxicity. Several non-pathogenic thermophilic Clostridial species are considered to have potential for the production of biofuel or organic acids, mainly due to their capacity to ferment cellulose or pentose sugars.

The clostridia are a diverse group of heterotrophic anaerobes. Many of them are able to metabolize a wide range of carbohydrate substrates. Jones et al. and Rogers et al. in their works justified that solventogenic clostridia have attracted interest principally due to their ability to produce organic acids and alcohols by fermentation [47, 48]. In the industrial scale acetone-butanol fermentation process which was used successfully earlier this century, Clostridium acetobutylicum was used to ferment starch or molasses [49]. But this process is currently uneconomic. Revival of this process and development of related processes will depend among other things on a thorough understanding of the biochemistry, physiology, and genetics of the organisms. These should allow optimization of conversion of the substrate to the desired end product. Despite the fact that 
accumulation of substrate is a potentially important metabolic control point, few detailed studies have been carried out on this aspect of the physiology of Clostridia [50]. Most of the cellulolytic Clostridial species produce a large extracellular multi-protein complex. They are capable of cellulose degradation known as cellulosome that is typical for anaerobic cellulolytic organisms [50]. Cellulosomes are important for the hydrolysis of plant biomass, because they are able to degrade not only cellulose, but also other components in plant cell walls [51].

The ABE fermentation process involves anaerobic bacteria, coming from genus clostridia to ferment treated biomass converting both sugars into acetone, butanol and ethanol. This process using genetically modified strains of $C$. acetobutylicum or $C$. beijerinckii strains of the Clostridia family is a promising process of biochemical conversion of biomass to biofuel. The focus of this field of research is to produce butanol instead of ethanol because of its advantages over bioethanol. Butanol has low vapour pressure and low water solubility as well as higher energy content than bioetha nol. It can also be used at a high percentage in current engines without modification.

Another added advantage is that it can be transported through current pipelines that are used for fossil fuels. Although the ABE process has been used industrially to produce butanol throughout the early 20th century, the economic and energetic cost of the process as compared to the fossil fuels is very high. One of the major challenges is the development of genetically modified microorganisms such as $C$. acetobutylicum and $C$. beijerinckii that will have high butanol tolerance during the fermentation process. Other promising techniques include energy efficient recovery of the butanol from the fermentation broth to prevent inhibition of the microorganism by fermentation. The current recurrence of the $\mathrm{ABE}$ process is because of the development of butanol tolerant strains of microorganisms. This also includes the development of energy efficient and cost effective techniques of recovering the butanol from fermented broth. 
The ABE process using Clostridia strains are promising especially for lignocellulosic biomass conversion, because of its natural ability to metabolize hexose and pentose simultaneously to produce acetone, butanol and ethanol. The microorganisms use a two stage process during fermentation [52]. During first Stage, acetic and butyric acids are produced until they build to inhibitory levels; then, the microorganisms enter the second stage, where solvent acetone, butanol, and ethanol are formed at a $\mathrm{pH}$ of 4-5. The start of this phase coincides of discrete butyric acid of $1 \mathrm{~g} / \mathrm{L}$, after solvent formations begin, the butyrate again decreases to trace levels, and the gases $\mathrm{CO}_{2}$ and $\mathrm{H}_{2}$ are co-products of the fermentation.

In Figure 2.7, arrow shows the direction of the metabolism in the solventogenic clostridia fermentation pathways. Acetate can be converted to butanol in the following sequence acetate $\rightarrow$ acetyl $\mathrm{CoA} \rightarrow$ acetoacetyl CoA $\rightarrow$ 3-hydroxybutyryl $\mathrm{CoA} \rightarrow$ crotonyl $\mathrm{CoA} \rightarrow$ butyryl CoA $\rightarrow$ butyraldehyde $\rightarrow$ butanol. The metabolism of solventogenic clostridia such as $C$. acetobutylicum and $C$. beijerinckii follows a series of biochemical reactions where polysaccharides and hexose, and pentose sugars are converted to Pyruvate, ATP, and NADH. C. acetobutylicum and C. beijerinckii utilize pyruvate to undergo biphasic fermentation where intermediate products, such as acetate and butyrate, are produced (acidogenesis) during exponential growth phase and re-assimilated during late exponential and stationary phases to produce $\mathrm{AB}$ (solventogenesis) (Figure 2.7). During acidogenic phase, solventogenic clostridia cells grow exponentially due to the production of high amounts of ATP. Under appropriate environmental conditions, acidogenic genes are induced and expressed. These genes regulate formation of relevant enzymes that bring about the catalysis of pyruvate to acetyl-CoA [53]. 


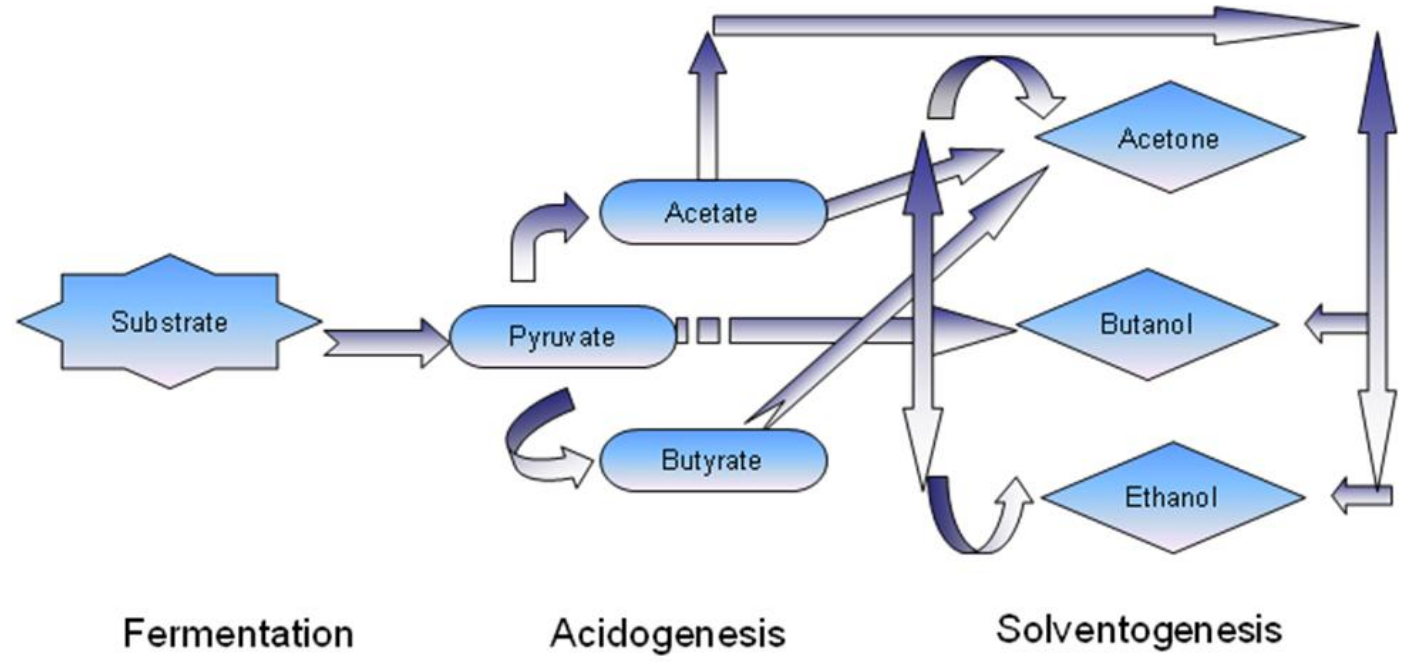

Figure 2.7. Phases of the AB E fermentation processes showing interactions of fermentation inter mediates directed toward ABE

(Adapted from Qureshi et al. [3]

In a normal batch culture, solvent-producing Clostridial species produce acetate and butyrate during the exponential growth phase. Only during the late growth phase the metabolism shift to rapid solvent production. This was first shown by Peterson and Fred [54] and Davies and Stephenson [55] and also by more recent studies with $C$. acetobutylicum [56]. The metabolic shift is also observed in $C$. beijerinckii [57]. Therefore, the shift in metabolic activity is accompanied by a corresponding shift in the cellular content of enzymes involved in the acid- and solvent-producing pathways (Figure 2.8). This happens when cells switch from the acid producing phase to the solvent-producing phase. The following equations represent the overall metabolism reactions of bio-based butanol fermentation [58]:

$\left(\mathrm{C}_{6} \mathrm{H}_{10} \mathrm{O}_{5}\right)_{12}+12 \mathrm{H}_{2} \mathrm{O} \rightarrow 12 \mathrm{C}_{6} \mathrm{H}_{12} \mathrm{O}_{6}$

Cellulose

Glucose

$12 \mathrm{C}_{6} \mathrm{H}_{12} \mathrm{O}_{6} \rightarrow 6 \mathrm{C}_{4} \mathrm{H}_{10} \mathrm{O}+4 \mathrm{C}_{3} \mathrm{H}_{6} \mathrm{O}+4 \mathrm{C}_{2} \mathrm{H}_{6} \mathrm{O}+16 \mathrm{H}_{2}+28 \mathrm{CO}_{2}+2 \mathrm{H}_{2} \mathrm{O}$

Glucose n-Butanol Acetone Ethanol 


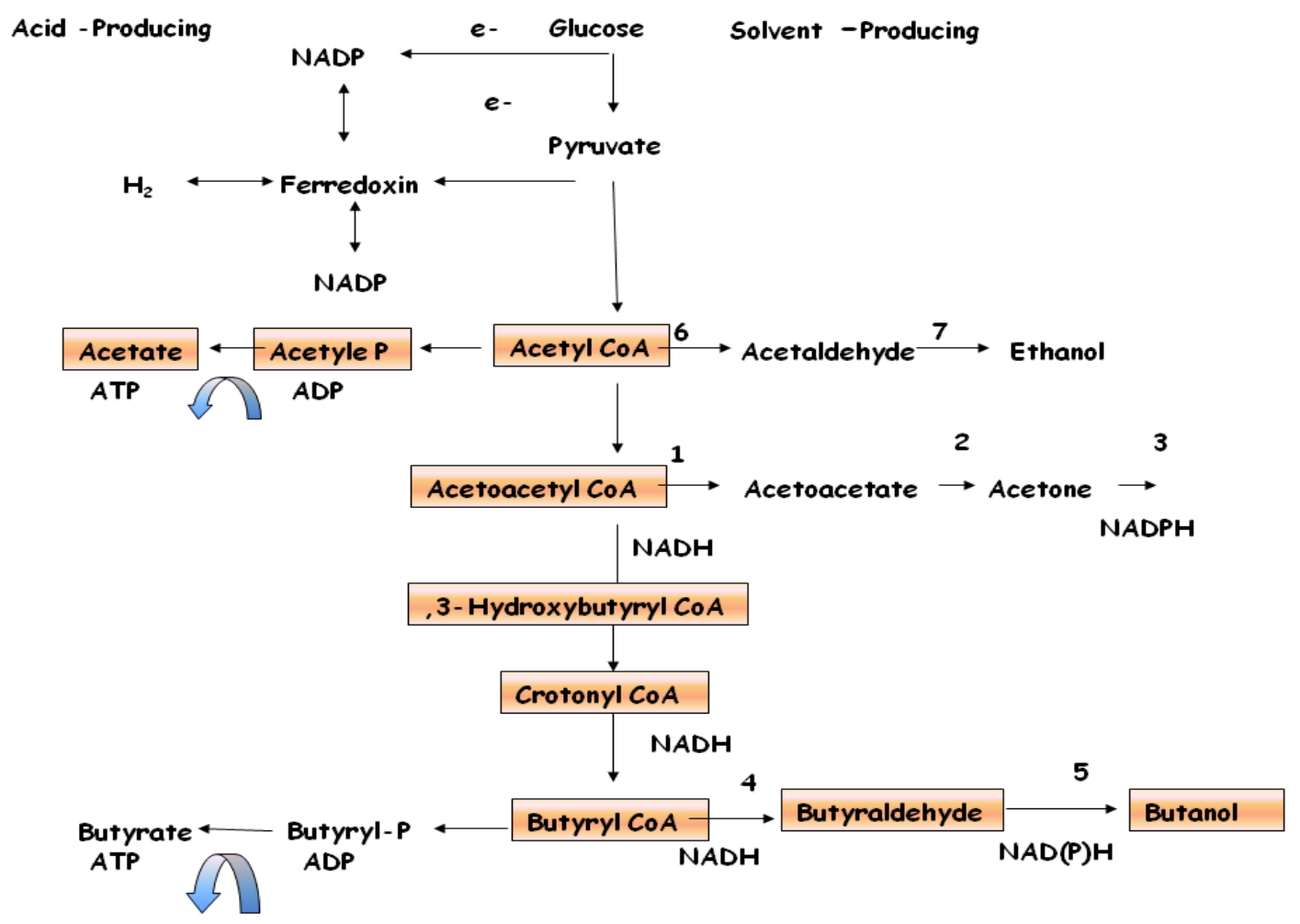

Figure 2.8. Metabolic path way of acetone-butanol-isopropanol ethanol fermentation

(Adapted from Jean Marc et al. [57])

The micro-organism used for butanol production will measure the maximum possible yields of butanol from available sugar. The mass-based theoretical yield of butanol from stoichiometry of glucose conversion shows of $0.41 \mathrm{~g}$ butanol/g glucose based on the formation of one mole butanol from every mole of glucose consumed. But this yield is not practically achievable, since other by-products are being produced in the biological process of fermentation (Equation 2.2). However, some microorganism strains could come remarkably close; Soni B.K. et al. [59] investigated on mutant strains that produce higher yield and higher tolerance to butanol toxicity than wild strains, whereas Sang L. et al. [60] showed that this only happens when mutant strains are normally generated by random mutagenesis. 
In the Figure 2.8, key enzymes involved in the final reactions of solvent production are: first, acetoacetyl-CoA: acetate/butyrate- CoA transferase or acetoacetyl-CoA hydrolase or both; second, acetoacetate decarboxylase; third, isopropanol dehydrogenase; fourth butyraldehyde dehydrogenase; fifth, butanol dehydrogenase; sixth, acetaldehyde dehydrogenase; finally, ethanol dehydrogenase.

\subsection{Pre-treatment and Hy drolys is}

The main technological problem in all biomass processing cases is to free the cellulose material in the plant and allow it to be converted without significantly reducing the yield of the existing cellulose material. This process is generally referred to as pre-treatment of the biomass. The effect of various pre-treatment processes on the enzymatic digestibility of pre-treated biomass residues is being appraised with the goal of lowering the overall costs of saccharifying biomass.

One of the first requirements for the utilization of lignocellulose for production of biofuel is to efficiently produce a fermentable hydrolysate, rich in glucose, from the cellulose present in the feedstock. Usage of enzymes for the hydrolysis of the lignocellulose is considered as the prospectively most viable strategy. This provides a cost-efficient, environmentally friendly process to avoid generation of by-products, because this may inhibit the subsequent fermentation [61, 62].

However, the physicochemical and structural composition of native lignocellulose hinders direct enzymatic hydrolysis of the cellulose and hemicellulose present in lignocellulosic biomass to increase the accessibility of the cellulose to enzymatic attack the lignocellulosic substrates; therefore, it is necessary to undergo a physicochemical pre-treatment before the enzymatic hydrolysis step [63].

Several different pre-treatment processes are efficient in providing a relatively easily degradable substrate [64]. In brief, pre-treatment may involve a mechanical step for reducing the substrate particle 
size of the native straw followed by one or more steps of heating and wetting the straw in the presence of a catalyst.

Acid, alkali or water itself at high temperature can be used as catalysts. With acid pre-treatment, the hemicellulose present in the straw is solubilised producing a solid fraction mainly of cellulose and lignin. The wet-oxidation and alkaline-based methods are relatively more effective at solubilizing lignin. These leave behind much of the hemicellulose in an insoluble, polymeric form [65].

The steam pre-treatment in conjunction with an acid catalyst is known to release the hemicellulose constituents of lignocellulose as oligosaccharides and monosaccharaides. Though, during the heat treatment some of the released monosaccharaides may be degraded to compounds inhibitory to both cellulase enzymes and the yeast during the subsequent fermentation step [66]. These inhibitory compounds include weak acids, furfural (from xylose), 5-hydroxymethyl furfural (from C6 monosaccharaides), and phenolic compounds from lignin [67]. Hot liquid water extraction is a particularly attractive pre-treatment process compared to steam explosion, because this pre-treatment involves no handling of harsh chemicals.

Moreover, hot liquid water extraction is reported to produce a liquid stream, which, in contrast to acid hydrolyzed steam pre-treated lignocellulose, does not inhibit the yeast during the fermentation step, where hemicellulose is mainly released as oligomers [68].

Apparently, the specific pre-treatment process will depend on a number of factors; this includes the origin of the lignocellulosic biomass such as softwood, hardwood, herbaceous energy crops or other agricultural residues and the amount and nature of inhibitory compounds. The use of a pre-treatment 
stage also depends on whether the $\mathrm{C}_{5}$ monosaccharaides are supposed to be utilized or not for the biofuel production [69].

Table 2.1 summarizes the sugar composition of typical agriculture residues using sulphuric acid and enzymatic hydrolysis pre-treatment; this would affect the metabolism of clostridia organis m and yield different fermentation products.

Table 2.1. Sugar content of agricultural residues

\begin{tabular}{|c|c|c|c|c|c|c|c|c|}
\hline & \multicolumn{2}{|c|}{ WS } & \multicolumn{2}{|c|}{ DDGS } & \multicolumn{2}{|c|}{$\mathrm{CF}$} & \multicolumn{2}{|c|}{ Molasses } \\
\hline Sugars & $\begin{array}{c}\text { Actual } \\
(\mathrm{g} / \mathrm{L})\end{array}$ & $\begin{array}{c}\mathrm{wt} / \mathbf{w t} \\
\%\end{array}$ & $\begin{array}{c}\text { Actual } \\
(\mathrm{g} / \mathrm{L})\end{array}$ & $\begin{array}{c}\mathrm{wt} / \mathrm{wt} \\
\%\end{array}$ & $\begin{array}{c}\text { Actual } \\
(\mathrm{g} / \mathrm{L})\end{array}$ & $\begin{array}{c}\mathrm{wt} / \mathrm{wt} \\
\%\end{array}$ & $\begin{array}{c}\text { Actual } \\
(\mathrm{g} / \mathrm{L})\end{array}$ & $\begin{array}{c}\text { wt/wt } \\
\%\end{array}$ \\
\hline Glucose & 28.9 & 48.0 & 23.6 & 44.9 & 37.2 & 53.4 & 14.0 & 25.0 \\
\hline Xylose & 20.1 & 33.4 & 16.7 & 31.7 & 17.6 & 25.3 & 0.0 & 0.0 \\
\hline $\begin{array}{c}\text { Arabinos } \\
\mathrm{e}\end{array}$ & 5.0 & 8.3 & 10.3 & 19.6 & 11.3 & 16.2 & 0.0 & 0.0 \\
\hline Galactose & 3.5 & 5.8 & 1.2 & 2.3 & 3.6 & 5.1 & 0.0 & 0.0 \\
\hline Mannose & 2.7 & 4.5 & 0.8 & 1.5 & 0.0 & 0.0 & 0.0 & 0.0 \\
\hline Sucrose & 0.0 & 0.0 & 0.0 & 0.0 & 0.0 & 0.0 & 28.0 & 50.0 \\
\hline Fructose & 0.0 & 0.0 & 0.0 & 0.0 & 0.0 & 0.0 & 14.0 & 25.0 \\
\hline $\begin{array}{c}\text { Total } \\
\text { sugar }\end{array}$ & 60.2 & $100 \%$ & 52.6 & $100 \%$ & 69.6 & $100 \%$ & 56 & $100 \%$ \\
\hline $\begin{array}{c}\text { Referenc } \\
\text { es }\end{array}$ & \multicolumn{2}{|c|}{ [7] } & \multicolumn{2}{|c|}{ [70] } & \multicolumn{2}{|c|}{ [71] } & \multicolumn{2}{|c|}{ [72] } \\
\hline
\end{tabular}

WS: Wheat straw DDGS: Dry Distiller Grain and Soluble CF: Corn Fiber

However, the crystalline structure of cellulose makes it difficult to hydrolyze; conventional production of biofuel from cellulose via fermentation involves a complex process of pre-treatment. This process includes: (i) cellulase production, (ii) hydrolysis of cellulose and hemicellulose (if present), followed by (iii) fermentation of hexose sugars generated by cellulose hydrolysis and pentose sugars generated by hemicellulose hydrolysis (if present). 
Cellulases are usually a mixture of several enzymes which are highly specific; at least three major groups of cellulases are involved in enzymatic hydrolysis process: 1) enzymes which attack regions of low crystallinity in the cellulose fibre, creating free-chain ends; 2) enzymes which degrades the molecule further by removing cellobiose units from the free-chain ends; 3) enzymes which hydrolyzes cellobiose to produce glucose [73].

Figure 2.9 shows the reaction pathway of the progression from the cellulose substrate to the glucose product through the activity of these three enzymes: endocellulase, exocellulase and $\beta$ glucosidase. The endocellulase and exocellulase enzymes incrementally cleave cellobiose molecules off of the long chain polysaccharide molecules. This cellobiose intermediate then becomes the substrate in the hydrolysis reaction with $\beta$-glucosidase, producing the final glucose product. Table 2.2 reviews the research work done utilizing agricultural residues for butanol fermentation processes. Cont rol experiment using glucose is also listed for base of comparison.

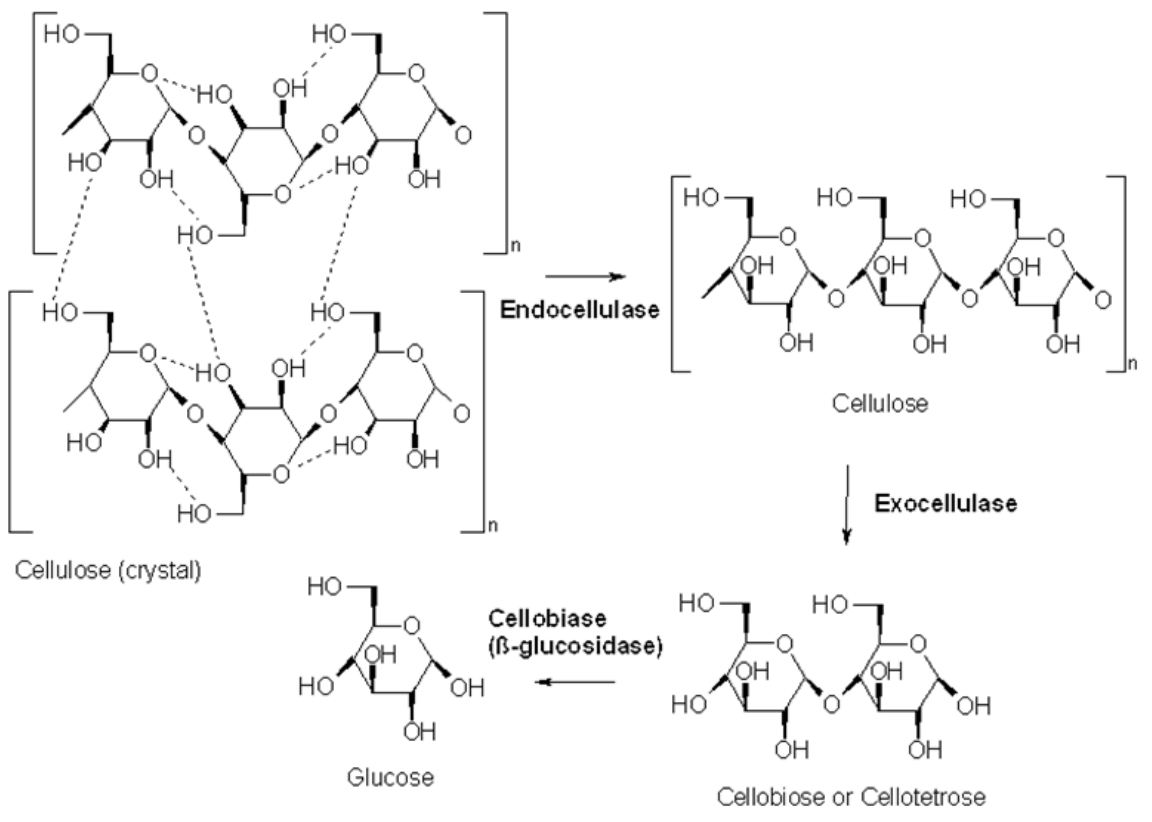

Figure 2.9. Reaction path ways from cellulose to glucose (Adapted from Technol ogy Road map, [32]) 
Table 2.2. Comparison of properties of most used agriculture residues for butanol production

\begin{tabular}{|l|c|c|c|c|c|c|}
\hline Feed Stock Type & WS & $\begin{array}{c}\text { WS }+ \\
\text { glucose }\end{array}$ & DDGS & $\begin{array}{c}\text { Corn } \\
\text { Fibers }\end{array}$ & \multicolumn{2}{|c|}{ Glucose (control) } \\
\hline Microorganism & $\begin{array}{c}\text { C. } \\
\text { beijerinckii } \\
\text { P260 }\end{array}$ & $\begin{array}{c}\text { C. } \\
\text { beijerinckii } \\
\text { P260 }\end{array}$ & $\begin{array}{c}\text { C. } \\
\text { beijerinckii } \\
\text { P260 }\end{array}$ & $\begin{array}{c}\text { C.beijerinck } \\
\text { ii P260 }\end{array}$ & $\begin{array}{c}\text { C. } \\
\text { beijerinckii } \\
\text { NRRL } \\
\text { B592 }\end{array}$ & $\begin{array}{c}\text { C.ijerinckii } \\
\text { P260 }\end{array}$ \\
\hline $\begin{array}{l}\text { ABE concentration } \\
\text { (g/L) }\end{array}$ & 21.40 & 28.00 & 8.10 & 9.30 & 15.00 & 20.10 \\
\hline ABE Yield & 0.41 & 0.42 & 0.48 & 0.39 & 0.25 & 0.41 \\
\hline Initial Sugar (g/L) & 62.10 & 93.10 & 52.60 & 25.00 & 50.00 & 62.00 \\
\hline $\begin{array}{l}\text { Sugar utilization } \\
\text { (g/L) }\end{array}$ & 52.00 & 68.00 & 16.50 & 23.60 & - & 49.00 \\
\hline $\begin{array}{l}\text { ABE Productivity } \\
\text { (g/L.h) }\end{array}$ & 0.31 & 0.63 & 0.34 & 0.10 & 0.27 & 0.28 \\
\hline pH & 5.00 & 6.50 & 4.80 & 6.80 & $4.70-5.00$ & 6.50 \\
\hline $\begin{array}{l}\text { Fermentation time } \\
\text { (h) }\end{array}$ & 72.00 & 72.00 & 72.00 & 72.00 & 1600.00 & 72.00 \\
\hline Temperature $\left({ }^{\circ} \mathrm{C}\right)$ & 35.00 & 35.00 & 35.00 & 35.00 & 34.00 & 35.00 \\
\hline Pretreatment type & $\begin{array}{c}\text { Acid }+ \\
\text { hydrolysis }\end{array}$ & $\begin{array}{c}\text { Acid }+ \\
\text { hydrolysis }\end{array}$ & $\begin{array}{c}\text { Acid }+ \\
\text { hyzyme } \\
\text { hydrolysis }\end{array}$ & $\begin{array}{c}\text { Acid }+ \\
\text { enzyme } \\
\text { hydrolysis }\end{array}$ & $\begin{array}{c}\text { Not } \\
\text { required }\end{array}$ & $\begin{array}{c}\text { Not } \\
\text { required }\end{array}$ \\
\hline Process type & Batch & Batch & Batch & Batch & $\begin{array}{c}2 \text { stages } \\
\text { Continuous }\end{array}$ & Batch \\
\hline $\begin{array}{l}\text { ABE recovery } \\
\text { technique }\end{array}$ & $\begin{array}{c}\text { Gas } \\
\text { stripping }\end{array}$ & stripping & None & None & $\begin{array}{c}\text { Gas } \\
\text { stripping }\end{array}$ & Gas \\
\hline Reference & {$[71]$} & {$[70]$} & $75]$ & {$[7]$} \\
\hline
\end{tabular}

\subsection{Process Configurations for Butanol production}

Process integration as it combines processes, such as pre-treatment, hydrolysis, fermentation, and recovery to be performed in a single unit. While use of economically available substrates, such as agricultural residues, is the most important need at this time. A combination of pre-treatment, fermentation, and product-separation techniques reduces total cost [76]. As a result, it has become the primary focus of the United States Department of Agriculture (USDA) and the National Center for Agricultural Utilization Research (NCAUR), in Illinois, to use agricultural residues such as corn fibre, xylan, wheat straw, barley straw, and energy crops including switch grass, for the production of biofuels, such as butanol and ethanol. 
Advanced technology makes possible to produce solvents from agricultural residues. Application of these substrates, development of efficient hydrolytic enzymes, and a combination of hydrolysis, fermentation, and recovery technologies has made this fermentation competitive with butanol obtained from petrochemicals. Besides, application of in situ product-recovery technologies has allowed the use of concentrated sugar solutions. The integrated processes listed in Table 2.3 displayed the production of more $\mathrm{AB}$ per liter culture volume than in the control batch fermentation process (non- integrated).

Table 2.3. A brief summary of $\mathrm{AB}$ production in bioreactors coupled with various product recovery systems

\begin{tabular}{|l|c|c|c|}
\hline \multicolumn{1}{|c|}{$\begin{array}{l}\text { Fermentation product recovery } \\
\text { system (substrate) }\end{array}$} & $\begin{array}{c}\text { AB/ABE } \\
\text { Substrate } \\
\text { concentration (g/L) }\end{array}$ & $\begin{array}{c}\text { Reduced (g/L } \\
\text { broth) }\end{array}$ & Refence \\
\hline $\begin{array}{l}\text { Control (Batch, glucose, no } \\
\text { recovery) }\end{array}$ & 48.9 & 20.1 & [7] \\
\hline Gas stripping (Fed-batch, glucose) & 500.0 & 232.8 & [77] \\
\hline $\begin{array}{l}\text { Perstraction (Batch, whey } \\
\text { permeate) }\end{array}$ & 227.0 & 99.3 & [7] \\
\hline Gas stripping (Batch, WSH) & & 47.6 & [79] \\
\hline $\begin{array}{l}\text { Pervaporation (Fed-batch, } \\
\text { glucose) }\end{array}$ & 128.3 & 119.0 & [80] \\
\hline $\begin{array}{l}\text { Pervaporation (Batch, glucose) } \\
\text { Gas stripping (Batch, whey } \\
\text { permeate) }\end{array}$ & 342.0 & 51.5 & [81] \\
\hline
\end{tabular}

${ }^{1}$ Culture volume $1.38 \mathrm{~L}$. Values in table are per liter broth (total sugar $313.3 \mathrm{~g}$, total ABE $137.0 \mathrm{~g}$ )

${ }^{2}$ Total sugars $128.3 \mathrm{~g} / \mathrm{L}$ including hexoses and pentoses

${ }^{3}$ Culture volumes 1-1.3 L. Values in table are per liter broth (total sugar $444.6 \mathrm{~g}$, total ABE $154.7 \mathrm{~g}$ ) 
Since batch reactors result in low reactor productivities, use of novel fermentation systems, such as free cell continuous fermentations, cell recycle, and immobilized cell reactors, have been explored. Continuous free cell systems offer comparatively higher productivities due to the elimination of down time. In these reactors, high cell concentration cannot be achieved as there is no means to retain cells in the reactor and hence cell washout occurs at high dilution rates.

For this reason, methods to retain high cell concentration inside the reactor, and still operate the reactor at high flow rates, have been developed [82]. These methods are known as "cell immobilization" and "cell recycle" systems. By using cell immobilization methods, cell concentrations in excess of 50-70 $\mathrm{g} / \mathrm{L}$ can be achieved in the reactor; such reactors can be operated at high flow rates with no cell washout. The added advantage of these systems is that they offer high reactor productivities due to the elimination of downtime and increased cell concentrations; increased reactor productivity results in the reduction of process vessel size and capital cost which improves process economics. Thus, immobilized cell reactor configurations can be packed or fluidized bed.

Cell recycle membranes are another source of increasing cell concentration. Unlike immobilized cell particles, the cells remain suspended in the liquid medium; a membrane is used as a means of preventing the cells from being removed with the out flow. Using membrane cell recycle reactors, cell concentrations as high as $90 \mathrm{~g} / \mathrm{L}$ can be achieved [83]. Using this approach, reactor productivities up to $6.5 \mathrm{~g} / \mathrm{L} . \mathrm{h}$ have been achieved in the butanol fermentation [84]. Some of the major limitations of cell recycle reactors include membrane fouling with fermentation broth, and high membrane cost.

An airlift bioreactor can be described as a bubble column containing a draught tube; many types of airlift bioreactors are currently in use today. Air is typically fed through a spurge ring into the bottom of a central draught tube that controls the circulation of air and the medium; air flows up the 
tube, forming bubbles, and exhaust gas disengages at the top of the column. The degassed liquid then flows downward and the product is drained from the tank. ALRs can be considered a type of bubble column since these are also pneumatically agitated; the main difference lies in the fluid flow, which depends on the geometry of the systems. The bubble column is a simple vessel where gas is injected, usually at the sensitive cultures are used. This offers advantages both for very high-volume, low-cost processes, and for small volume processes producing high value products, particularly animal and cell plant cultures.bottom; random mixing of the medium is caused by the ascending bubbles. On the other hand, the major patterns of fluid circulation within the ALR are determined by the bioreactor design. The special characteristics of ALRs make them advantageous for some processes, especially when shear-

\subsection{Butanol Tole rance}

Significant research efforts have focused on developing or genetically improving butanol producing cultures, which can tolerate elevated levels of acetone-butanol concentration ranging from 20.0-30.0 g/L. In a recent report, microbial cultures, such as Escherichia coli have been developed for producing butanol with concentration in the range of 14-16 g/L. The newly developed butanolproducing strain cannot tolerate butanol in excess of $15 \mathrm{~g} / \mathrm{L}$ as butanol is more toxic than isobutanol [85]. Likewise, butanol concentration above $25 \mathrm{~g} / \mathrm{L}$ is toxic to C.beijerinckii BA101 [86]. The aim of the present study is to introduce a novel approach by using an improved microorganism strain, Clostridium fusant, that is formed through protoplast fusion to produce butanol by simultaneous saccharification and fermentation; nevertheless, because of small scale production, butanol did not show toxicity. 
For enhanced butanol tolerance, an effective solution can be addressed in two ways: i) use of genetic engineering techniques to develop strains that could tolerate higher concentration of butanol and ii) use of engineering techniques to ferment and remove products simultaneously; thus, toxic butanol concentration inside the reactor is never reached. Employing the first approach, cultures have been developed for the toleration and production of up to $30 \mathrm{~g} / \mathrm{L} \mathrm{AB}$ [23]. However, butanol when present at $13 \mathrm{~g} / \mathrm{L}$ in the fermentation medium becomes toxic to the culture due to its hydrophobic nature [87].

The primary reason for producing low butanol concentration is its toxicity. In this concern, recovery technology can give the solution; simultaneous removal of $\mathrm{ABE}$ will not allow high concentration of butanol in the fermentation broth. Usually, product-removal techniques include gas stripping, adsorption, liquid-liquid extraction, perstraction, pervaporation, and reverse osmosis. Simultaneous removal of ABE has been exercised in batch, fed-batch, and continuous immobilized cell reactors. It should be noted that removal of $\mathrm{ABE}$ from batch and fed-batch systems can be directly applied to existing fermentation industries which are not likely to make changes to their existing infrastructure [3].

\subsection{Protoplast Fusion}

A system for the genetic manipulation of $C$. acetobutylicum and the closely related $C$. beijerinckii would allow strain improvement, which could improve the economic feasibility of this industrial process; this also increases the knowledge of the regulation on fermentation [88]. The primary methods for producing genetic recombination in gram-positive bacteria of industrial importance have been protoplast fusion [89] and transformation [90]. This recombination occurs because the DNA of two kinds of non-divided cells co-exist inside a cell during fusion. The method is 
primarily used for cell function improvement and is well-known process to change the genetic characteristics of microorganisms without the need of complicated engineering techniques [91].

There have been reports of protoplast formation and regeneration of certain strains of $C$. acetobutylicum, [92, 93] while there are no reports of protoplast manipulation techniques for $C$. beijerinckii. Allcock, et al. [93], and Reilly and Rogers [92] reported protoplast fusion of $C$. acetobutylicum. Birrer, et al. [94] studied the formation and regeneration of protoplasts of $C$. beijerinckii as a step in developing a genetic system for this species. They developed a protocol and medium that would yield stable protoplasts of $C$. beijerinckii B-592 and allow the protoplasts to regenerate their cell walls. Their method of forming protoplasts from $C$. beijerinckii is similar to the method reported for C. acetobutylicum by Reilly and Rogers [95].

Figure 2.10 (a) shows a distinctive L-colony (arrow) growing next to a bacillary colony of $C$. beijerinckii B-592 on a BLM plate and Figure 2.10 (b) is shown a photograph of a BRM plate on which L-colonies has been transferred, which exhibits the radical change in colonial morphology that accompanies regeneration of an L-colony. The large spreading colonies are bacillary colonies of B-592.
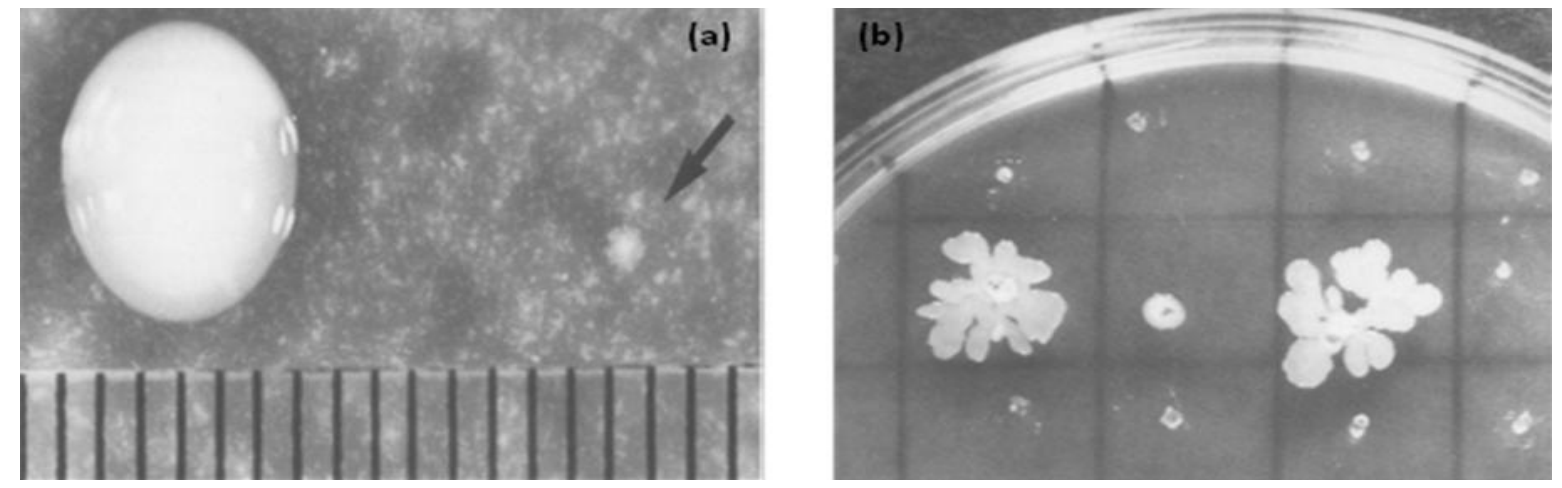

Figure 2.10. (a) Clostridium beijerinckii B-592 growing on B LM medium. (b) L-colonies of C. beijerinckii (Adapted from Birrer et al. [94]) 
Enhancement in regeneration of protoplasts is a priority for developing the genetics of solvent producing clostridia. Pioneering work on the preparation and regeneration of protoplasts of saccharolytic clostridia of industrial interest has been done during this decade in Clostridium acetobutylicum [93]. The potential of the fermentation system would be greatly improved with the development of genetic transfer systems for the bacterium, enabling the use of genetic manipulation techniques for the production of novel products in large fermenters which do not require aeration. As an initial step in the development of genetic transfer systems in C. acetobutylicum, formation and regeneration of protoplasts have been successfully used with other bacteria for the transfer of plasmids by transformation and protoplast fusion $[95,96]$.

\subsection{Enzyme Assay}

Cellulose is a polymer consisting of glucose linked only by $\beta 1,4$ bonds. As we move from laboratory research by microbiologists and biochemists to pilot plant and development studies by chemical engineers and industrialists, it is necessary to look at cellulose saccharification once dealing with agriculture residues in the feedstock. This should be considered in a quantitative and economic manner where as a major cost factor will be the cost of cellulase enzymes. Cellulase is a complex of enzymes containing chiefly endo-, exo- $\beta$-glucanases and cellobiase. But cellulose samples of different origin vary widely in chain length and the degree of interaction between the chains [97]. Furthermore, lignocellulosic biomass usually consists of only $30 \%$ to $40 \%$ cellulose with the balance consisting of hemicelluloses, lignins, and other materials. Many cellulase preparations also contain hemicellulases. If they are present, the hemicelluloses are rapidly hydrolyzed since they are much less recalcitrant to enzyme action than is cellulose.

Amorphous cellulose is also rapidly hydrolyzed and then the rate of hydrolysis decreases greatly as the increasingly crystalline portions of the cellulose are attacked [98]. Cellulase activity is 
mainly evaluated using a reducing sugar assay to measure the end products of cellulase hydrolysis activities. Thus, the results of such an assay are typically expressed as the hydrolysis capacity of the enzymes. Many different cellulase activity assays have been used and developed over the last few decades. Table 2.4 illustrates cellulase assays based on individual, total and miscellaneous enzyme activity.

Table 2.4. Cellulase Assays (Adapted from Mandels et al. [98])

\begin{tabular}{|c|c|c|}
\hline Enzy me & Substrate & Product measured \\
\hline \multicolumn{3}{|l|}{ Cellobiase } \\
\hline \multirow[t]{4}{*}{$\beta$ Glucosidase } & Cellobiose & Glucose \\
\hline & Cellodextrins & \\
\hline & Salicin & Salingenin \\
\hline & p-Nitro b glucosidase & p Nitrophenol \\
\hline \multicolumn{3}{|l|}{ Endo b 1, 4 glucanase } \\
\hline $\mathrm{Cx}$ & Carboxymethyl cellulose & Loss in viscosity \\
\hline \multirow[t]{4}{*}{ CMC'ase } & Amorphous cellulose & Reducing sugar \\
\hline & Walseth & \\
\hline & Sweco & \\
\hline & Cellodextrins & \\
\hline \multicolumn{3}{|l|}{ Exo $\beta 1,4$ Glucanase } \\
\hline A Glucocellulase & Amorphous cellulose & Glucose (A) \\
\hline B Cellobiohydrolase & Walseth & \\
\hline $\mathrm{CBH}$ & Crystalline cellulose & Cellobiose (B) \\
\hline \multirow[t]{2}{*}{$\mathrm{C}_{1}$} & Avicel & \\
\hline & Cellodextrins & \\
\hline \multicolumn{3}{|l|}{ Cellulase } \\
\hline $\mathrm{C}_{1}+\mathrm{C}_{\mathrm{x}}$ & Crystalline cellulose & Loss in weight \\
\hline Avicellase & Avicel & Reducing sugar \\
\hline Hydrocellulase & Hydrocellulose & Reduction in optical density (OD) \\
\hline \multicolumn{3}{|l|}{ FP'ase } \\
\hline & Filter paper & \\
\hline & Cellodextrins & \\
\hline & Cotton & \\
\hline \multicolumn{3}{|l|}{ Miscellaneous } \\
\hline Swelling factor & Cotton & Uptake of alkali \\
\hline \multirow[t]{3}{*}{ Filter paper cellulase } & Filter paper & Maceration [1] \\
\hline & Thread & Breaking strength \\
\hline & Dyed cellulose & Release of dye \\
\hline
\end{tabular}

$C M C=$ Carboxymethyl cellulose $; F P=$ Filter paper . 
The objective of the current study is to use the thermostable fused strains to enhance enzymatic activity during the SSF by raising the incubation temperature and thereby eventually increasing biobutanol production. Economic and residence time analysis of SSF found that addition of cellulase increases the cost of fermentation and prolongs biobutanol production cycle. However, results from the current study indicated that the fused strains, at the higher temperature, were able to produce the required enzymes for the hydrolysis of wheat straw (i.e., endoglucanase, exoglucanase, and $\beta$ glucosidase). This will have a major impact on eliminating costs associated with adding enzymes as raw material to the saccharification process. 


\section{CHAPTER 3}

\section{MATERIALS AND METHODS}

\subsection{Che micals and Materials}

C. beijerinckii ATCC BA101 and C. acetobutylicum ATCC 4259 were purchased from American Type Culture Collection whereas $C$. thermocellum was obtained from Dr. Wolfaardt's Lab at Ryerson University. Furthermore, Table 5 summarizes all chemicals that were used throughout this work. All the chemicals were used as received without any further purification.

Table 3.1. List of che micals and enzymes applied in the current study

\begin{tabular}{|l|l|l|}
\hline Product & Company & Catalogue No. \\
\hline $\begin{array}{l}\text { Reinforced Clostridial Medium } \\
\text { (RCM) }\end{array}$ & Oxoid Ltd. (Basingstoke, Hampshire, UK) & CM0149 \\
\hline Cooked Meat Medium (CMM) & Oxoid Ltd. (Basingstoke, Hampshire, UK) & MT0350 \\
\hline Glucose & Sigma-Aldrich (St. Louis, MO) & G8769 \\
\hline D-biotin & Sigma-Aldrich (St. Louis, MO) & B4501 \\
\hline PABA & Sigma-Aldrich (St. Louis, MO) & 6930 \\
\hline Thiamine- $\mathrm{HCl}$ & Sigma-Aldrich (St. Louis, MO) & T4625 \\
\hline FeSO ${ }_{4} \cdot 7 \mathrm{H}_{2} \mathrm{O}$ & Sigma-Aldrich (St. Louis, MO) & F8048 \\
\hline $\mathrm{MnSO}_{4} \cdot 4 \mathrm{H}_{2} 0$ & Sigma-Aldrich (St. Louis, MO) & M7634 \\
\hline $\mathrm{MgSO}_{-} \mathrm{H}_{2} \mathrm{O}$ & Sigma-Aldrich (St. Louis, MO) & 63138 \\
\hline $\mathrm{H}_{2} \mathrm{SO}_{4}$ & Sigma-Aldrich (St. Louis, MO) & 339741 \\
\hline $\mathrm{KH}_{2} \mathrm{PO}_{4}$ & Sigma-Aldrich (St. Louis, MO) & 322431 \\
\hline $\mathrm{K}_{2} \mathrm{HPO}_{4}$ & Sigma-Aldrich (St. Louis, MO) & GO139 \\
\hline NaOH & Sigma-Aldrich (St. Louis, MO) & S5881 \\
\hline DNS acid & Sigma-Aldrich (St. Louis, MO) & D0550 \\
\hline $\begin{array}{l}\text { Sodium potassium tartrate } \\
\text { tetrahydrate }\end{array}$ & Sigma-Aldrich (St. Louis, MO) & 217255 \\
\hline Oxonol & Sigma-Aldrich (St. Louis, MO) & 75926 \\
\hline propidium iodide & Sigma-Aldrich (St. Louis, MO) & 70335 \\
\hline Starch & Sigma-Aldrich (St. Louis, MO) & S5651 \\
\hline Maltose & Sigma-Aldrich (St. Louis, MO) & M9171 \\
\hline Xylanase & Sigma-Aldrich (St. Louis, MO) & X2753 \\
\hline Celluclast 1.5L & Sigma-Aldrich (St. Louis, MO) & C2730 \\
\hline Novozyme 188 & Sigma-Aldrich (St. Louis, MO) & S7653 \\
\hline NaCl & Sigma-Aldrich (St. Louis, MO) & \\
\hline
\end{tabular}




\subsection{Prepa ration and Handling Protoplast Fused Strains}

Three novel fused strains were prepared in our laboratory facility at Ryerson (supervised by Dr. Yaser Dahman) as part of previously conducted work. All fused strains were stored in the ultra low freezer at $-80^{\circ} \mathrm{C}$ together with the wild strains of $\mathrm{Ca}$ and $\mathrm{Cb}$. Error! Reference source not found. displays a list of five different bacterial strains that were examined in the present work. As shown in this table, two wild Clostridial strains (i.e.,Clostridium acetobutylicum, Clostridium beijerinckii) were fused with the thermally stable Clostridium thermocellum. Fused strains were prepared by former fellows following the the protocol proposed by Birrer et al. [94].

Table 3.2. Clostridium wild and fused strains used in the study course of Batch SSF

\begin{tabular}{|l|l|}
\hline Symbol & Clostridium wild and its fused strains \\
\hline $\mathrm{Ca}$ & Clostridium acetobutylicum \\
\hline $\mathrm{Cb}$ & Clostridium beijerinckii \\
\hline $\mathrm{CaCb}$ & Clostridium acetobutylicum Clostridium beijerinckii \\
\hline $\mathrm{CaCt}$ & Clostridium acetobutylicum Clostridium thermocellum \\
\hline $\mathrm{CbCt}$ & Clostridium beijerinckii Clostridium thermocellum \\
\hline
\end{tabular}

\subsubsection{Medium Preparation for Fusion}

Culture Clostridium basal medium (CBM), Protoplasting medium (PPM), Reinforced Clostridial medium (RCM) CM0149, Agar based Regeneration Medium (RM), and Cooked meat medium (CMM) MT0350 were used for protoplast fusion. Table 3.1 summarizes all the chemicals used to prepare the mediums for protoplast fusion. 
Table 3.3. Compositions of different me dia used throughout protoplast fusion

\begin{tabular}{|c|c|}
\hline Medium & Compositions \\
\hline $\mathrm{CBM}$ & $\begin{array}{l}\text { Glucose, } \mathrm{MgSO}_{4} .7 \mathrm{H} 2 \mathrm{O}, \mathrm{MnSO}_{4} \cdot 4 \mathrm{H} 2 \mathrm{O}, \mathrm{FeSO} 4.7 \mathrm{H} 2 \mathrm{O} \text {, } \\
\text { p-amino benzoic acid (PABA), Biotin, thiamin } \mathrm{HCl} \text { and } \\
\text { Casein hydrolysate }\end{array}$ \\
\hline PPM & CBM, Sucrose, $\mathrm{CaCl}_{2} .2 \mathrm{H}_{2} \mathrm{O}$ and $\mathrm{MgCl}_{2} .6 \mathrm{H}_{2} \mathrm{O}$. \\
\hline CMM & $\begin{array}{l}\text { (Provided from supplier) Beef heart solids, casein/meat peptone, dextrose and sodium } \\
\text { chloride }\end{array}$ \\
\hline $\mathrm{RM}$ & $\begin{array}{l}\text { Biotin, p-amino benzoic acid (PABA), thiamin- } \mathrm{HCl}, \mathrm{FeSO}_{4} .7 \mathrm{H}_{2} \mathrm{O} \\
\mathrm{MnSO}_{4} 4 \mathrm{H}_{2} \mathrm{O} \mathrm{MgSO}_{4} .7 \mathrm{H}_{2} \mathrm{O} \text {, glucose, } \mathrm{MgCl}_{2}, \mathrm{CaCl}_{2}, \mathrm{~K}_{2} \mathrm{HPO}_{4}, \\
\mathrm{KH}_{2} \mathrm{PO} 4 \text {, water, gelatin, Agar, Yeast extract, Casamino acids, L-asparagine. }\end{array}$ \\
\hline
\end{tabular}

Clostridium Basal Medium (CBM) is a medium used to grow wild and fused Clostridium strains and was prepared by adding $2 \mathrm{~g}$ Glucose, $0.04 \mathrm{~g} \mathrm{MgSO}_{4} .7 \mathrm{H} 2 \mathrm{O}, 0.002 \mathrm{~g}$ of $\mathrm{MnSO}_{4} \cdot 4 \mathrm{H}_{2} \mathrm{O}, 0.002 \mathrm{~g}$ of $\mathrm{FeSO}_{4} .7 \mathrm{H}_{2} \mathrm{O}, 0.0002 \mathrm{~g}$ of Para-Amino benzoic acid (PABA), 0.004 $\mathrm{g}$ of Biotin, $0.00002 \mathrm{~g}$ of thiamin $\mathrm{HCl}$ and $0.8 \mathrm{~g}$ of Casein hydrolysate in $200 \mathrm{ml}$ water [99]. The CBM medium was used for growing Clostridium cultures (Errol R. Allcock 1982). Protoplasting Media (PPM) was prepared by adding to CBM, $0.3 \mathrm{M}$ Sucrose, $50 \mathrm{mM} \mathrm{CaCl}{ }_{2} \cdot 2 \mathrm{H}_{2} \mathrm{O}$ and $50 \mathrm{mM} \mathrm{MgCl}_{2} \cdot 6 \mathrm{H}_{2} \mathrm{O}$. The solution was autoclaved (SANYO labo autoclave, USA) at $120^{\circ} \mathrm{C}$ for 20 min [3]. This medium along with PEG was used for generation of protoplasts during protoplast fusion [92]. Regeneration Medium (RM) is an essential medium for growing bacterial colonies and was prepared by the addition of stock solutions to a basal mixture. Stock solutions A to E were prepared for making RM. Stock solution A contains $1 \mathrm{~g} / \mathrm{L}$ biotin, 1g/L Para Amino Benzoic acid (PABA), 0.1 g/L thiamin- $\mathrm{HCl}, 1 \mathrm{~g} / \mathrm{L} \mathrm{FeSO}_{4} \cdot 7 \mathrm{H}_{2} \mathrm{O}, 1 \mathrm{~g} / \mathrm{L} \mathrm{MnSO}{ }_{4} .4 \mathrm{H}_{2} \mathrm{O}$ and $20 \mathrm{~g} / \mathrm{L}$ of $\mathrm{MgSO}_{4} .7 \mathrm{H}_{2} \mathrm{O} .100 \mathrm{ml}$ of Stock solution A was prepared and filter sterilized and kept in $\mathrm{N}_{2}$ atmosphere. Stock solution B was made by adding $25 \mathrm{~g}$ glucose in $100 \mathrm{ml}$ of $\mathrm{H}_{2} \mathrm{O}$. Stock solution $\mathrm{C}$ 
comprised of 2.5 $\mathrm{M}$ solution of $\mathrm{MgCl}_{2}$. Stock D solution consists of $2.5 \mathrm{M}$ solution of $\mathrm{CaCl}_{2}$ and finally stock solution E consists of $7.0 \mathrm{~g}$ of $\mathrm{K}_{2} \mathrm{HPO}_{4}$, and 3.0g of $\mathrm{KH}_{2} \mathrm{PO}$, dissolved in $100 \mathrm{ml} \mathrm{H}_{2} \mathrm{O}$. Stock solutions B through E were autoclaved separately. Basal Mixture contains 50g gelatin, 15g Agar, 8g Yeast extract, 2.5g Casamino acids, $1 \mathrm{~g} \mathrm{~L}$-asparagine. These ingredients were mixed in $930 \mathrm{ml} \mathrm{H}_{2} \mathrm{O}$ and the mixture was stirred and brought to boiling before autoclaving at $121^{\circ} \mathrm{C}$ for 20 min [94]. Upon cooling, $10 \mathrm{ml}$ of stock solution A and $40 \mathrm{ml}$ of solution B was added to the basal mixture. To make the $\mathrm{RM}$ medium, $5 \mathrm{ml}$ of each of solutions $\mathrm{C}$ and $\mathrm{D}$ was added along with $10 \mathrm{ml}$ of stock solution $\mathrm{E}$.

This viscous medium was then poured into petri dishes and allowed to set until they form a smooth solid surface for the bacteria to grow. These are Agar streak plates and are an essential tool in microbiology. They allow bacteria and fungi to grow on a semi-solid surface to produce discrete colonies. Cooked meat medium supplemented with $0.1 \%$ glucose [100] was used to maintain bacterial strains.

\subsubsection{Protoplast Fusion Formation}

The fusion process that was conducted in our laboratory consists of three major steps: Formation of protoplast, fusion and regeneration (of cell wall around the fused protoplast). To prepare for the first step, overnight cultures of the wild strains were harvested by centrifugation at $10,600 \times \mathrm{g}$ for $10 \mathrm{~min}$ and then were diluted 1:4 with fresh, sterile CBM broth containing $0.4 \%$ or $0.8 \%$ glycine [94]. After 45-60 min when the cultures become nearly $100 \%$ motile, the osmotic strength of each culture was increased by suspending in $5 \mathrm{ml}$ Protoplasting medium (PPM). The $\mathrm{pH}$ was adjusted to 7.5. Lysozyme $(2.5 \mathrm{mg} / \mathrm{ml}$, Chicken egg white grade1) was added to the cell suspension and incubated at $35^{\circ} \mathrm{C}$ for $30-60 \mathrm{~min}$. After $60 \mathrm{~min}$, the PPM cell suspension was centrifuged at $3300 \mathrm{x}$ for $5 \mathrm{~min}$ to extract the protoplast pellets and were resuspended in fresh PPM medium without lysozyme. The protoplast pellets can be directly used if the fusion is to be performed the same day or can be stored by resuspending in fresh PPM without lysozyme. The protoplast remains intact in this medium [94]. 
Protoplast formation was performed for C. acetobutylicum, C. beijerinckii and C.thermocellum individually. Protoplasts of $C$. acetobutylicum were mixed with C.thermocellum and that of $C$. beijerinckii were mixed with C.thermocellum before sedimenting by centrifugation at $1500 \mathrm{~g}$ at $20^{\circ} \mathrm{C}$, and the pelleted protoplasts were gently resuspended in $1 \mathrm{ml}$ polyethylene glycol (PEG) 4000 (40\%, w/v) in PPM for 2-3min. Dilutions of the fused protoplasts were plated onto regeneration medium (RM) and incubated at $34^{\circ} \mathrm{C}$ for 2 days [101]. A sterile inoculating loop was used to streak the fused protoplast onto the agar plates (RM). The loop was sterilized by holding it under a flame until it is red hot. The agar plates are placed in anaerobic jars and sealed tightly before incubating them at $34^{\circ} \mathrm{C}$ for 2 days. The colonies were extracted and suspended in CBM medium with 30\%(v/v) sterile glycerol at $82^{\circ} \mathrm{C}$ in eppendorf tubes [102].

\subsection{Inocula Pre paration and Culture Conditions}

The stock cultures of all Clostridium wild and fused strains were kept at $-82^{\circ} \mathrm{C}$ inside the freezer (Thermo fisher scientific, USA) and maintained as a cell suspension in $30 \% \mathrm{v} / \mathrm{v}$ sterile glycerol in Eppendorf tubes. Prior to the SSF experiments, inocula were prepared using these wild and fused strains, whereas all manipulations involving cells were carried out in a Glove Box (Terra Universal, Canada) at a mean temperature of $25 \pm 2{ }^{\circ} \mathrm{C}$ (Figure 3.1).

Reinforced Clostridial Medium (RCM) CM0149 [101], Cooked Meat Medium (CMM) MT0350 [101] and Clostridium basal medium $(C B \mathrm{M})$ [101] were used in the current study for the culture activation of $C$. acetobutylicum ATCC 4259, C. beijerinckii ATCC BA101, and the fused strains ( $C a C b, C a C t, C b C t$, see Table 3.2), respectively. Both CMM and RCM media were obtained from the supplier, and were prepared by dissolving $12.5 \mathrm{~g}$ and $3.8 \mathrm{~g}$ respectively in $100 \mathrm{~mL}$ distilled $\mathrm{H}_{2} \mathrm{O}$ in separate vessels. RCM is composed of yeast extract (3 g), lab chemo powder (10 g), peptone (10 g), 
soluble starch (1 g), glucose (5 g), cysteine hydrochloride (0.5 g), sodium chloride (5 g), sodium acetate $(3 \mathrm{~g})$ and agar $(0.5)$. Two basic vitamins were required to maintain active growth of the culture, which were biotin and p-aminobenzoic acid. All media were sterilized by autoclaving (SANYO labo autoclave, USA) at $121^{\circ} \mathrm{C}$ for 20 minutes, and allowed to cool down to room temperature.

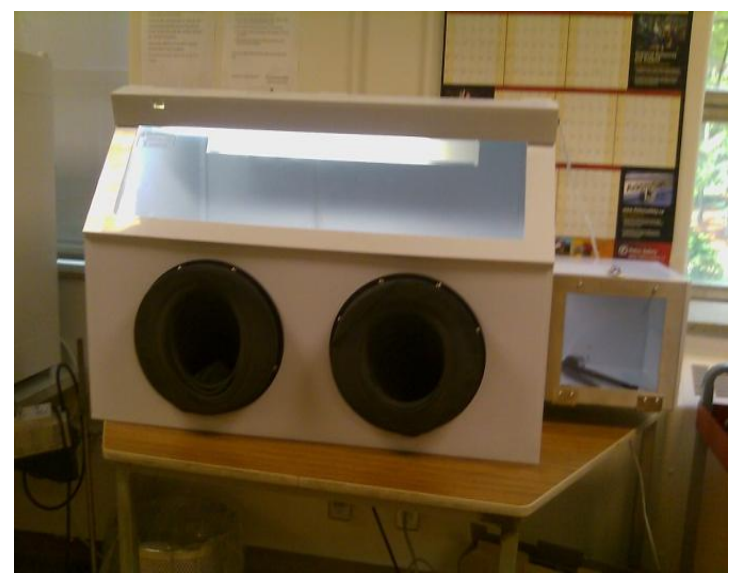

Figure 3.1. Glove box used in the present work

For the inoculation of the wild strains and their fused strains, actively growing cells were inoculated in $80 \mathrm{ml}$ of inoculum development medium in $250 \mathrm{ml}$ Wheaton serum bottles inside a Glove box ( 8 vol\% stock culture) under sterile and nitrogen blanket (continuous purging of $\mathrm{N}_{2}$ ). To create an anaerobic environment inside the box, air was initially evacuated from the box by using a vacuum pump for 10 minutes. Following that, $\mathrm{N}_{2}$ gas was purged thoroughly during the procedure for inoculation and continued until all the Wheaton serum bottles were properly crimped. After being sealed, serum bottles were put inside the incubator at $35^{\circ} \mathrm{C}$ for 3 days for inoculation. Simultaneously, cells of the fusants (i.e., $C a C b, C a C t$ and $C b C t$ ) were inoculated with $C B \mathrm{M}$ in separate bottles inside the anaerobic box under $\mathrm{N}_{2}$ blanket. Finally, $C a C t$ and $C b C t$ cultures were allowed to grow for three days at $45^{\circ} \mathrm{C}$ while $\mathrm{CaCb}$ was kept in an incubator at $35^{\circ} \mathrm{C}$ for the same duration of time. After three days of inoculation, all the cultures were ready for inoculation within the biobutanol production medium. 


\subsection{Wheat Straw Pre-treatment}

The wheat straw was collected from the Spring ridge Farm, (Milton, ON, Canada) and stored initially at room temperature. Before use, WS was grounded to fine particles (physical pretreatment) using $1 \mathrm{~mm}$ sieve screen in a hammer mill (Retsch GmbH Inc., USA) shown in Figure 3.2 [7]. The moisture content of the wheat straw was reduced through heating in a convention oven at $105^{\circ} \mathrm{C}$ for 10 h until constant weight was obtained.

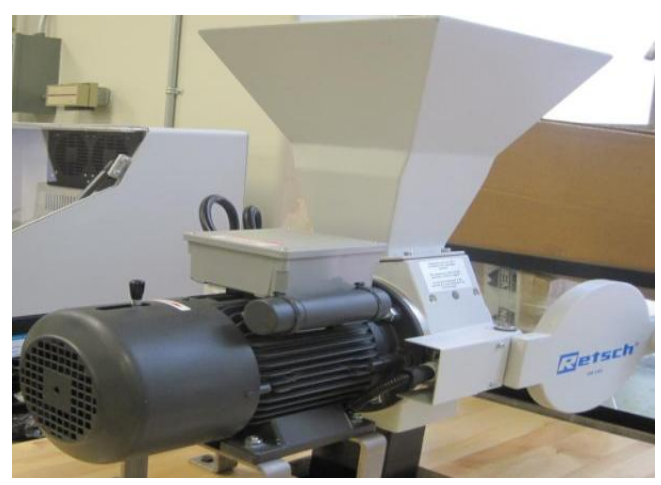

Figure 3.2. Hammer mill that was used to prepare whe at straws

Acidic pre-treated WS was done through suspending $4.3 \mathrm{~g}$ in $50 \mathrm{~mL}$ of $1 \%$ dilute sulphuric acid $\left(\mathrm{H}_{2} \mathrm{SO}_{4}\right)$ in $250 \mathrm{ml}$ Wheaton serum bottles [6]. Stock solution of $1 \%$ dilute sulphuric acid was prepared by mixing $10 \mathrm{~mL}$ sulphuric acid with $990 \mathrm{ml}$ distilled water. The WS mixtures were then a utoclaved at $121^{\circ} \mathrm{C}$ for 60 minutes. The lost water due to the autoclaving was added to maintain constant volume. After autoclaving, the mixture was cooled down to room temperature followed by adjusting the $\mathrm{pH}$ to 6.5 using $10 \mathrm{M}$ sodium hydroxide $(\mathrm{NaOH})$ [7, 74]. Following that, the WS mixtures were used to pursue SSF experiments.

\subsection{Wheat Straw Hydrolysis}


Acidic pre-treated $\left(1 \% \mathrm{H}_{2} \mathrm{SO}_{4}\right)$ wheat straw (4.3 g) of two serum bottles was autoclaved for 60 min at $121^{\circ} \mathrm{C}$. Upon autoclaving, the mixtures were cooled to room temperature followed by adjusting $\mathrm{pH}$ to 5.0 with $10 \mathrm{M} \mathrm{NaOH}$ [7]. Hereafter, $3 \mathrm{~mL}$ each of three enzyme solutions (Celluclast $1.5 \mathrm{~L}$ (cellulose, novozyme 188 and xylanase) were added and mixed well. Finally, the mixture bottles were incubated at two different temperatures of $35^{\circ} \mathrm{C}$ and $45^{\circ} \mathrm{C}$ for $72 \mathrm{~h}$ with agitation at $80 \mathrm{rpm}$. After incubation, the WS hydrolysate was filtered twice using an $11 \mu \mathrm{m}$ pore size and $110 \mathrm{~mm}$ diameter Whatman filter paper to remove sediments. Following this, the clear supernatant was sterilized by passing through a $0.2 \mu \mathrm{m}$ filter. The sterilized solution was stored in a pre-sterilized screw capped serum bottle at $4^{\circ} \mathrm{C}$ for sugar quantification to be conducted later. Table 3.4 shows the hydrolysate sugars concentrations obtained using the HPLC.

Table 3.4. Wheat straw hydrolysate sugars at two diffe rent te mperature

\begin{tabular}{|c|c|c|c|c|c|c|}
\hline WSH & $\begin{array}{c}\text { Glucose } \\
(\mathbf{g} / \mathbf{L})\end{array}$ & $\begin{array}{c}\text { Xylose } \\
(\mathrm{g} / \mathrm{L})\end{array}$ & $\begin{array}{c}\text { Arabinose } \\
(\mathrm{g} / \mathrm{L})\end{array}$ & $\begin{array}{c}\text { Mannose } \\
(\mathrm{g} / \mathrm{L})\end{array}$ & $\begin{array}{c}\text { Galactose } \\
(\mathrm{g} / \mathrm{L})\end{array}$ & Total hydrolysate \\
\hline $35^{\circ} \mathrm{C}$ & 21.08 & 18.23 & 11.77 & 1.6 & 2.52 & 55.2 \\
\hline $45^{\circ} \mathrm{C}$ & 27.78 & 21.34 & 5.5 & 2.33 & 2.63 & 59.59 \\
\hline
\end{tabular}

\subsection{Simultaneous Saccharification and Fermentation Expe riments}

In the current study, batch SSF experiments were conducted to produce acetone, biobutanol and ethanol ( $\mathrm{ABE}$ ) by using the bacterial using the pre-treated WS as described above. SSF studies were carried out in $250 \mathrm{ml}$ Wheaton serum bottles at two different temperatures $\left(35^{\circ} \mathrm{C}, 45^{\circ} \mathrm{C}\right)$. Each of the SSF experiments was analyzed for the amount of sugar consumed in addition to ABE solvent, acids, 
and inhibitors produced. Figure 3.3 summarizes procedure for the batch Simultaneous Saccharification and Fermentation of biobutanol.

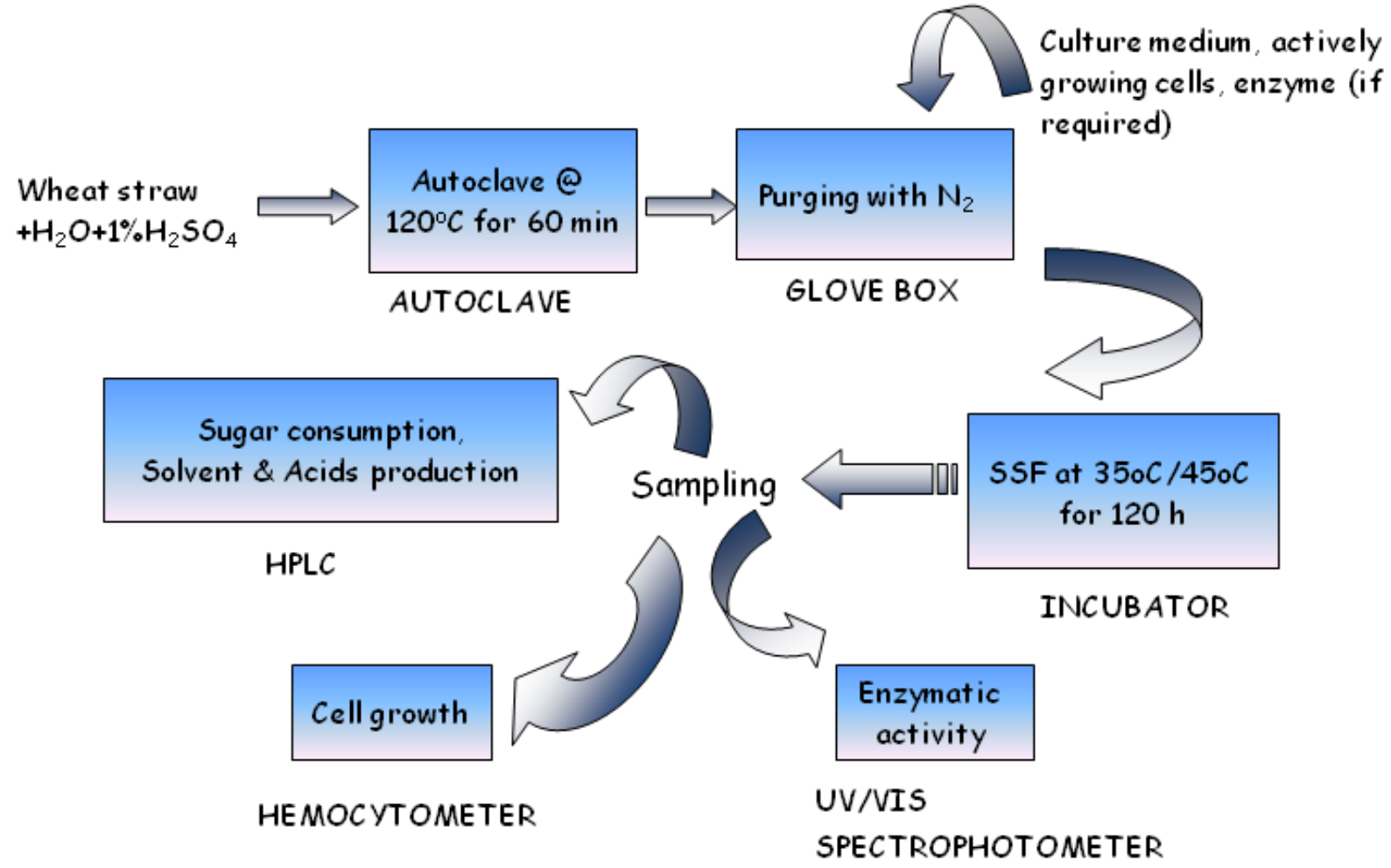

Figure 3.3. Proce dure for anaerobic batch simultane ous saccharification and fermentation of biobutanol

At $35^{\circ} \mathrm{C}$, two parental strains $(C a, C b)$ and its three fusants $(C a C b, C a C t$ and $C b C t)$ were used in the SSF experiments. Physically pre-treated wheat straw (4.3 g) with dilute sulphuric acid was simultaneously saccharified with enzymes and fermented at $35^{\circ} \mathrm{C}$. After autoclaving wheat straw mixture, $\mathrm{pH}$ of the solution was brought to approximate 6.5 using $10 \mathrm{M}$ sodium hydroxide. Inside the anaerobic hood, $40 \mathrm{~mL}$ of culture medium and $7 \mathrm{~mL}$ of actively growing cells culture were added into the solution. Nitrogen was continuously purge inside the box to create an anaerobic condition. After sealing the blue neoprene stopper, the serum bottles were kept inside the incubator for SSF at $35^{\circ} \mathrm{C}$. During SSF, $2 \mathrm{~mL}$ of each sample was taken at the different period of time and prior to testing. The samples were double filtered through $0.2 \mu \mathrm{m}$ PTFE- filter (Whatman, USA) for sugars, ABE, and acid measurement. SSF was conducted at $35^{\circ} \mathrm{C}$ until the culture ceased $\mathrm{ABE}$ production. 
At $45^{\circ} \mathrm{C}$, WS was chemically pre-treated with dilute sulphuric acid. It was saccharified and fermented by employing just the two fusants $(\mathrm{CaCt}$ and $\mathrm{CbCt}$ ) for biobutanol production. The $\mathrm{pH}$ of the wheat straw mixture was brought to 6.5 after cooled down to the room temperature. The culture medium was added at the same level followed by developing anaerobic condition and inoculation with $7 \mathrm{~mL}$ culture. This study was also carried out in $250 \mathrm{~mL}$ Wheaton serum bottles with $40 \mathrm{~mL}$ of the medium for each sample. SSF was conducted as described above; three types of enzymes (Celluclast, Novozyme 188 and xylanase) were added for comparison (0.3 mL of each). Figure 3.4 displays experimental units during SSF.

\subsection{Sampling}

For all fermentation experiments and culture inocula, sampling was made inside the biosafety hood cleaned with ethanol and left in the UV light for $10 \mathrm{~min}$. All other tools such as syringes and needles were washed with ethanol and left under the UV light for 10 minutes as well. The serum fermentation batches were taken out of incubator, placed inside biosafety hood and washed with ethanol prior to sampling. According to [58], 1.5 moles of hydrogen and 2.33 moles of carbon dioxide gases are expected to be produced for each mole of sugar consumed. However, a sampling method was designed to capture fermentation gases inside fermentation bottles until the end of fermentation. This was achieved by inserting a sterilized syringe-needle combination through the serum bottle's rubber stopper and sampling only the liquid phase of fermentation medium which contained the liquid products (solvents, acids, sugars) and the culture cells, while leaving the gases to continue their role in fermentation process. Four-milliliter samples were taken every $24 \mathrm{~h}$ and kept until analyzed in $2 \times 2-\mathrm{ml}$ Eppendorf tubes and kept at $-82^{\circ} \mathrm{C}$ inside the ultra- low freezer (Thermo, Canada). 


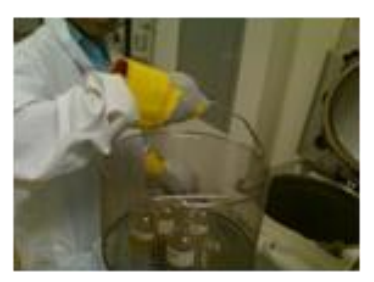

Autoclaving

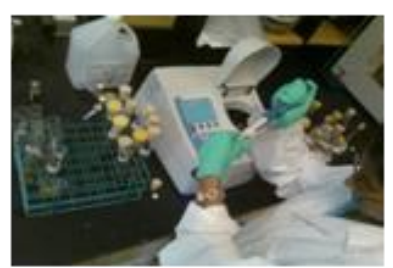

UVNIS

spectrophotometer

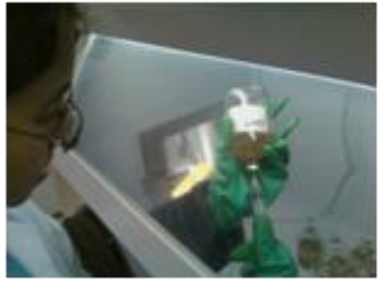

Glove box

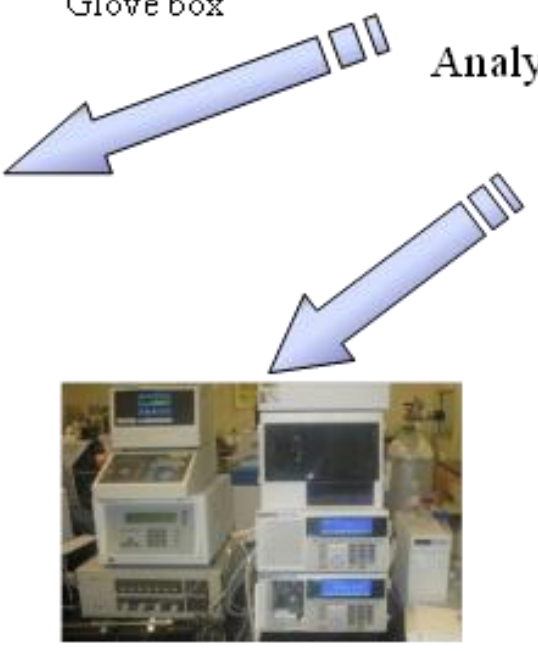

HPLC

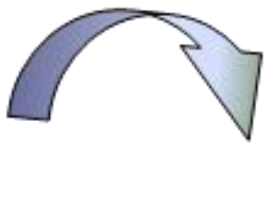

Analysis

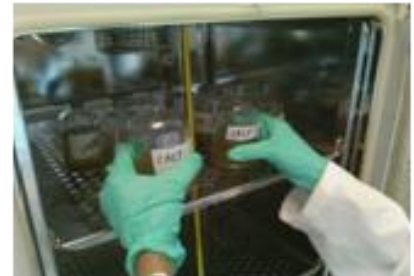

Incubator
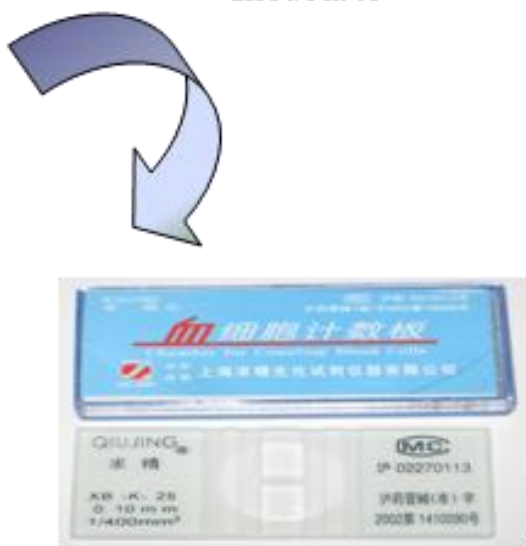

Hemocytometer

Figure 3.4. Experimental steps during conducting B atch SSF

\subsection{Enzyme Assay}

Total cellulase activities for all strains were quantified by the application of filter paper that is known as the filter paper assay (FPA) which was developed by Mandels et al. [98] and reviewed by [103]. The International Unit (IU) of filter paper activity (FPase) (FPU) is defined as the micromole of glucose equivalent liberated per minute of culture filtrate under assay conditions. Assay conditions are the $\mathrm{pH}$ and temperature at which the enzymes are held under during the assay. This depends largely on the properties of the enzyme and it varies widely between cellulases and the different microorganisms [103, 104]. 


\subsubsection{Filter Paper Assay (FPA)}

In order to measure the enzyme activities for different strains during the SSF, samples collected were centrifuged at $5000 \mathrm{rpm}$ for 10 minutes (Sorvall Legend Micro 21R Centrifuge, England) and supernatants were double filtered through $0.2 \mu \mathrm{m}$ PTFE- filters (Whatman, USA). Sample values were corrected for any blank values. The substrate is a $50 \mathrm{mg}$ Whatman No. 1 filter paper strip $(1.0 \times 6.0 \mathrm{~cm})$ [105].

To prepare DNS reagent, $10.6 \mathrm{~g}$ of 3,5 Dinitrosalicylic acid and $19.8 \mathrm{~g}$ of Sodium hydroxide were dissolved in $1416 \mathrm{~mL}$ distilled water. Following that, $306 \mathrm{~g}$ of Rochelle salts (sodium potassium tartrate), $7.6 \mathrm{~mL}$ of Phenol (melt at $50^{\circ} \mathrm{C}$ ) and $8.3 \mathrm{~g}$ of Sodium metabisulfite were added respectively and were mixed well. Then $3 \mathrm{~mL}$ of this sample was titrated with $0.1 \mathrm{~N} \mathrm{HCl}$ to the phenolphthalein endpoint [105]. To prepare citrate buffer, $210 \mathrm{~g}$ of Citric acid monohydrate was dissolved in $750 \mathrm{~mL}$ of deionised water (DI). Buffer $\mathrm{pH}$ of 4.3 was adjusted by adding $\mathrm{NaOH}$ (solid, 50 to $60 \mathrm{~g}$ ) and diluted to $1 \mathrm{~L}$ to make $1 \mathrm{M}$ stock solution. The stock was diluted with DI water to $50 \mathrm{mM}$ and $\mathrm{pH}$ of 4.8 was achieved [105].

Filter paper strip (50 mg) was rolled and placed into each test tube. Na-citrate buffer of $1.0 \mathrm{~mL}$ $0.05 \mathrm{M}, \mathrm{pH} 4.8$ was added to the tube so that the buffer could saturate the filter paper strip. All the tubes were placed in the water bath to reach equilibrium with buffer and substrate to $50^{\circ} \mathrm{C}$. Following that, $0.5 \mathrm{~mL}$ enzyme dilution with citrate buffer was added to each tube. For each enzyme sample, five dilutions were made of for the assay to carry on so that at least one dilution releasing slightly more than $2.0 \mathrm{mg}$ of glucose (absolute amount) and one slightly less than $2.0 \mathrm{mg}$ of glucose [105].

For reagent blank, $1.5 \mathrm{~mL}$ citrate buffer was taken into the test tube. For enzyme control, 1.0 $\mathrm{mL}$ citrate buffer were mixed with $0.5 \mathrm{~mL}$ enzyme dilution and was prepared a separate control for 
each dilution tested. Substrate control was prepared by $1.5 \mathrm{~mL}$ citrate buffer that was saturated filterpaper strip. A working stock solution of anhydrous glucose $(10 \mathrm{mg} / \mathrm{mL})$ was made up. Aliquots of this working stock were tightly sealed and stored frozen at $-82^{\circ} \mathrm{C}$. The standard should be vortexes after thawing to ensure adequate mixing. Glucose standard tubes were prepared by adding $0.5 \mathrm{~mL}$ of each of the glucose dilutions to $1.0 \mathrm{~mL}$ of citrate buffer in a $13 \times 100 \mathrm{~mm}$ test tube.

Blanks, controls and glucose standards were incubated at $50^{\circ} \mathrm{C}$ along with the enzyme assay tubes, and then the enzyme reaction was stopped at the end of 60 minutes by addition of $3.0 \mathrm{~mL}$ of DNS reagent.

All test tubes were boiled for exactly 5 minutes in a vigorously boiling water bath containing sufficient water to cover the portions of the tubes occupied by the reaction mixture and reagent. All samples, controls, blanks, and glucose standards were boiled together. After boiling, they were transferred to a cold ice-water bath until all the pulps were settled. All tubes (assays, blanks, standards and controls) were diluted in water, $0.200 \mathrm{~mL}$ of color-developed reaction mixture along with $2.5 \mathrm{~mL}$ of water in a spectrophotometer cuvette works well Color formation was determined by measuring absorbance against the reagent blank at $540 \mathrm{~nm}$ [106].

\subsubsection{Calculation of Enzyme Activity}

Linear glucose standard curve was plotted using the absolute amounts of glucose $(\mathrm{mg} / 0.5 \mathrm{~mL})$ against $\mathrm{A}_{540}$. Using this standard curve, the amount of glucose released for each sample tube was determined after subtraction of enzyme blank. The concentration of enzyme was measured, which would have released exactly $2.0 \mathrm{mg}$ of glucose by means of a plot of glucose liberated against the logarithm of enzyme To find the required enzyme concentration, two data points were taken, both were 
find very close to $2.0 \mathrm{mg}$ and drew a straight line between them. Then, this line was used to interpolate between the two points to find the enzyme dilution that would produce exactly $2.0 \mathrm{mg}$ glucose equivalents of reducing sugar (Appendix D). In this plot along with Equation (3.1) for calculating FPU, the term "enzyme concentration" refers to the proportion of the original enzyme solution present in each enzyme dilution [105].

Filter Paper Activity $=\frac{0.37}{[\text { enzyme }] \text { releasing } 2 m g \text { of glucose }}\left(\frac{\text { units }}{m L}\right)$

Where, [enzyme] represents the proportion of original enzyme solution prese nt in the directly tested enzyme dilution, of which $0.5 \mathrm{~mL}$ is added to the assay mixture.

\subsection{Specific Growth Rate}

Specific growth rate defines the fraction of increase in biomass over a unit time, i.e. an increase of certain g-biomass from every gram of existing biomass per hour. Specific growth rate represents the average growth rate of all cells present in a culture. The expression of the rate of microbial growth as specific growth rate is crucial to avoid the effect of cell concentration; $\mu$ represents the specific growth rate (g-biomass/g-biomass/h or $\mathrm{h}^{-1}$ ) of the culture. Monod model (Equation 3.2) introduced the concept of growth-limiting substrate $(S)$, relating the specific growth rate $(\mu)$ to the concentration of a single growth-limiting substrate via two parameters, the maximum specific growth rate $\left(\mu_{\max }\right)$, and the Monod's constant or saturation constant $\left(K_{s}\right)$. The growth rate has been shown by Monod to be related to the concentration of substrate medium by the Equation 3.2.

$\mu=\left(\mu_{\max } \cdot S\right) /\left(K_{s}+S\right)$ 
where,

$\mu=$ specific growth rate;

$\mu_{\max }=$ maximum specific growth rate unlimited by low concentrations of the substrate;

$S=$ substrate concentration; and

$K_{S}=$ concentration of substrate that supports a rate equal to $\mu_{\max } / 2$

With the linearization method, the specific growth rate is determined by calculating the difference in the natural log of the biomass concentrations over time, corresponding to the exponential growth phase was plotted, Straight lines were obtained with slopes equal to $\mu$ and intercepts equal to lag phase time, for each set of experiments carried out.

Figure 3.6 (a) represents dry cell mass (g/L) vs. time (h) for the Clostridium fused strain $\mathrm{CaCt}$ at $35^{\circ} \mathrm{C}$. This figure reveals that lag phase of $18.5 \mathrm{~h}$ was found during conducting SSF, exponential growth phase were started after $24 \mathrm{~h}$ of fermentation and late exponential growth were found after $72 \mathrm{~h}$ of fermentation and remained until the culture ceased production or stationary phase begins. From Figure 3.6(b), it may be said that specific growth rate was found among three points of 2, 3 and 4 and straight line with slope was found of $\mathrm{y}=0.040 \mathrm{x}+0.8056$ where specific growth rate is $0.040 \mathrm{~h}^{-1}$ [107]. Following this, $\ln [(\mathrm{DCM}(\mathrm{g} / \mathrm{L})]$ vs. time $(\mathrm{h})$ for all other Clostridium species and its fused strains at two different temperatures of $35^{\circ} \mathrm{C}$ and $45^{\circ} \mathrm{C}$ were plotted (Appendix C) during the batch SSF. 


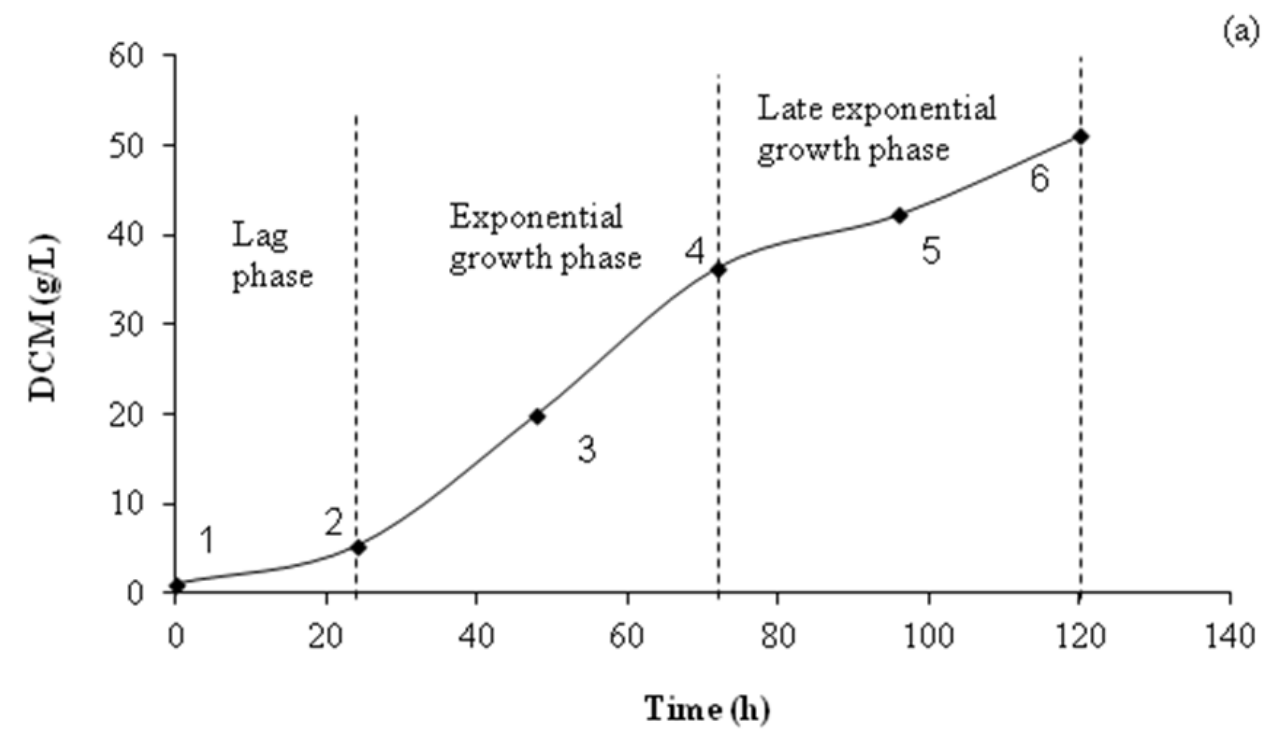

(b)

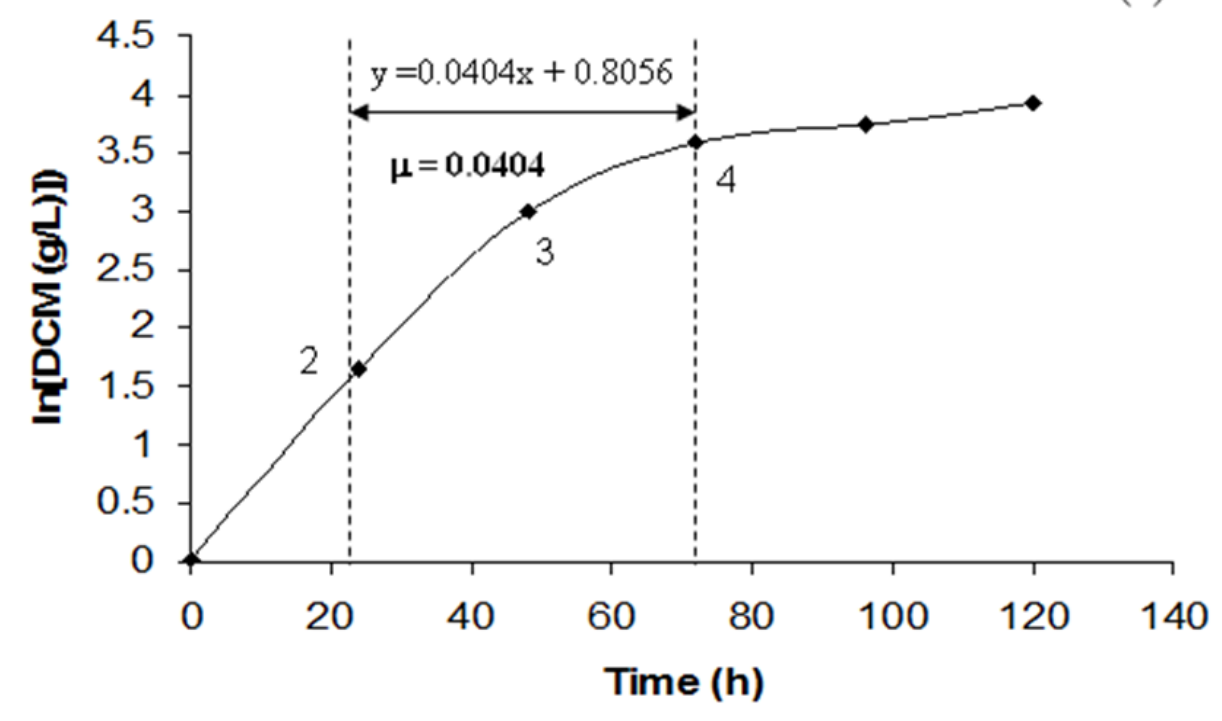

Figure 3.5. Cell growth of fused strain $\mathrm{CaCt}$ at $35^{\circ} \mathrm{C}$ : (a) Dry cell mass over fermentation time; (b) Natural $\log$ of DCM over fermentation time

\subsection{Analytical Techniques}

\subsubsection{Hemocytometer}

Viable cell counting was determined using a hemocytometer (QiuJing XB-K-25) having $1 / 400 \mathrm{~mm}^{2}$ unit area and $0.1 \mathrm{~mm}$ high. The counting was done under optical microscope (Zeiss Axio 
Observer A1) at 50X magnification. Samples were diluted 20 folds and stained with florescent dye (Bac Light ${ }^{\mathrm{TM}}$, Bacterial Viability and Counting Kit) to differentiate between viable and nonviable cells. The data presented in the appendix A (Table A.14 to A.24) represent the average of 3 separate counts.

\subsubsection{UV/VIS Spectrophotometer}

Enzymes activity was measured by using pre-calibrated UV/VIS scanning spectrophotometer shown in Figure 3.6. Glucose standard curve was plotted using the absolute amounts of glucose $(\mathrm{mg} / 0.5 \mathrm{~mL})$ against A540. Samples were analyzed by measuring absorbance against the reagent blank at $540 \mathrm{~nm}$. Prior to analysis, all tubes (sample assay, blanks, standards and controls) were diluted in water $(0.2 \mathrm{~mL}$ of color developed reaction mixture along with $2.5 \mathrm{~mL}$ of water in a spectrophotometer cuvette works well).

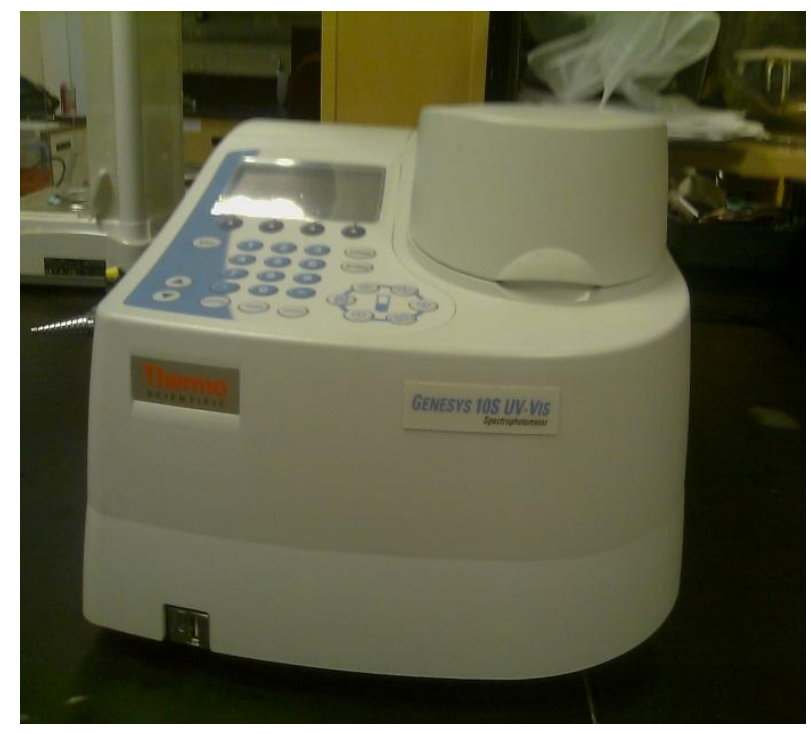

Figure 3.6. GENES YS 10S UV-VIS Spectrophotometer (ThermoFisher Scientific, USA)

\subsubsection{High Performance Liquid Chromatography (HPLC)}

Sample size of $1 \mathrm{~mL}$ was taken after each time interval for quantitative analysis for $\mathrm{ABE}$, acids, sugars and inhibitor (furfural) concentrations. These samples were stored at $-80^{\circ} \mathrm{C}$ until analyzed. 
Sugars concentrations were measured using high performance liquid chromatography (HPLC-Perkin Elmer) equipped with an automatic sample injector and a refractive index detector (2414, Waters) which is illustrated in Figure 3.7. Three HPLC columns were used called Shodex KC811 for measuring sugars, Shodex SP0810 to measure inhibitors, and Aminex HPX-87H to measure ABE solvent and acids concentrations. The samples were centrifuged at $15000 \mathrm{~g}$ for $15 \mathrm{~min}$ and double filtered through $0.2 \mu \mathrm{m}$ PTFE- filter (Whatman, USA). The solvent (mobile phase, $5 \mathrm{mM} \mathrm{H} \mathrm{HO}_{2} \mathrm{SO}$ ) was filter sterilized and autoclaved at $121^{\circ} \mathrm{C}$ for 15 min. Following that, solvent was degassed using a vacuum filtration. A blank sample with only double distilled water was applied in the first sample vial tray of HPLC. This blank was used to increase the flow rate of the solvent from $0.0 \mathrm{ml} / \mathrm{min}$ to $0.6 \mathrm{ml} / \mathrm{min}$. The flow rate was maintained at $0.6 \mathrm{ml} / \mathrm{min}$ for $1 \mathrm{~h}$ while, increasing the temperature of the HPLC column from $20^{\circ} \mathrm{C}$ to $60^{\circ} \mathrm{C}$. This also fixes the pressure at a constant value and cancels some noise created during the analysis. Then each sample vials were injected with $0.1 \mu$ in sequence. Each sample was analysed through the HPLC for 30 min. Data were processed by the computer software (Turbochrom Navigator). It was important to fill the HPLC testing vials to a minimum head space to reduce the loss of solvents in vapor phase. The reliability of HPLC column, and testing parameters were confirmed by running solvents, acids, and sugars standards in triplicate.

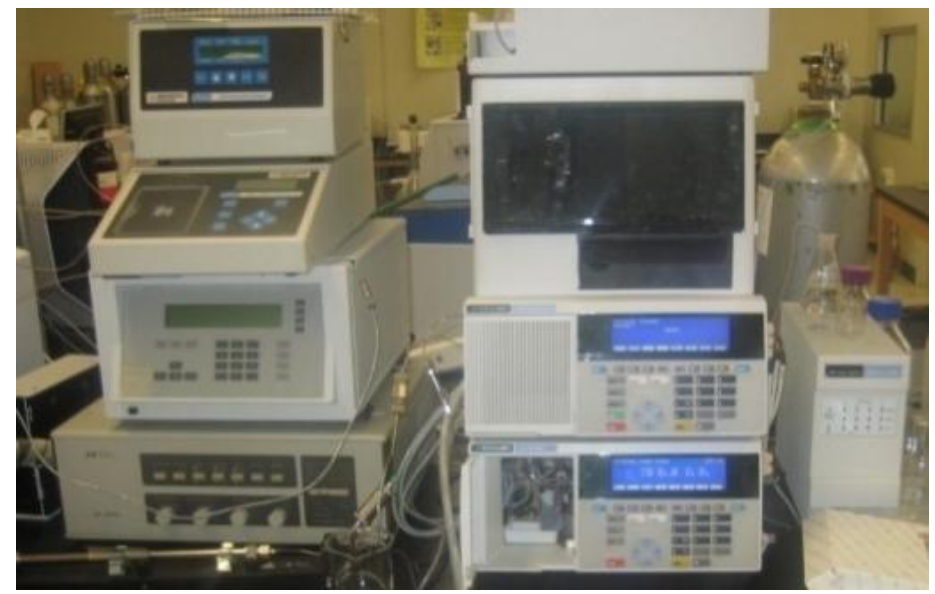

Figure 3.7 HPLC (Perklin Emer) supplied with Refractive index (RI; model: HP 1047A; Hewlett Packard). 


\subsection{Error Analysis}

Each experiment in the present work was repeated three times, and the reported results represent the average value of the data collected. Table A.1 and A.2 in Appendix A show results that were measured for the replicate experiments for production of $\mathrm{ABE}$ and acids by Clostridium species and its fused strains at two different temperatures. Similarly, Table A.3 and A.4 represent the results for biobutanol production in batch process using Clostridium species at various SSF times at $35^{\circ} \mathrm{C}$ and $45^{\circ} \mathrm{C}$ whereas Table A.5 to A.15 display the results for bacterial cells growth with time during the SSF experiments by Clostridium species and its fused strains. Error percentages were calculated for all results reported based on the replicated experiments in Tables A.5 to A.15, and were in the range of: 1.30 to $2.58 \%$ for total ABE production; 6 to $14 \%$ for total acids production; 2.70 to $10.20 \%$ for biobutanol production and 0.20 to $2.30 \%$ for bacterial cell count.

In chapter 4, error bar has been shown on each graph followed by error analysis. The standard deviation (STDEV) was calculated according to the simple following correlation [108].

$$
S T D E V=\sqrt{\frac{\sum(X-\bar{X})^{2}}{(n-1)}}
$$

Where,

$\bar{x}=$ sample mean value;

$\mathrm{n}=$ sample size;

Standard error of the mean (STERROR) was calculated from the value of STDEV. The STERROR can be written as [108]:

$S T E R R O R=\frac{S T D E V}{\sqrt{n}}$

Where,

STDEV = standard deviation of the samples; 
$\mathrm{n}=$ sample size;

Error percentage was calculated from the equation shown below.

Error Percentage $(\%)=\frac{\operatorname{STDEVX100}}{\bar{X}}$ 


\section{CHAPTER 4}

\section{RESULTS AND DISCUSSION}

\subsection{ABE and Acids Production}

The first stage of metabolism includes acidogenesis, where feedstock carbohydrates are converted into multiple acids (i.e., acetic acid and butyric acid). Following that, the microbes shifts to solventogenesis (second stage) and begins consuming the acids to produce the correlated ABE (i.e., ethanol, biobutanol, and acetone). The advantage of this class of microbes is that they do consume acids and produce associated solvents [109]. Production of ABE (i.e., ethanol, biobutanol, and acetone) and acids (i.e., acetic acid and butyric acid) were analyzed in the SSF experiments conducted with the different wild and fused strains of bacteria at $35^{\circ} \mathrm{C}$ and $45^{\circ} \mathrm{C}$ with and without the addition of hydrolysis enzymes. Figure 4.1 shows the total amounts of $\mathrm{ABE}$ and acids that were produced at $35^{\circ} \mathrm{C}$.

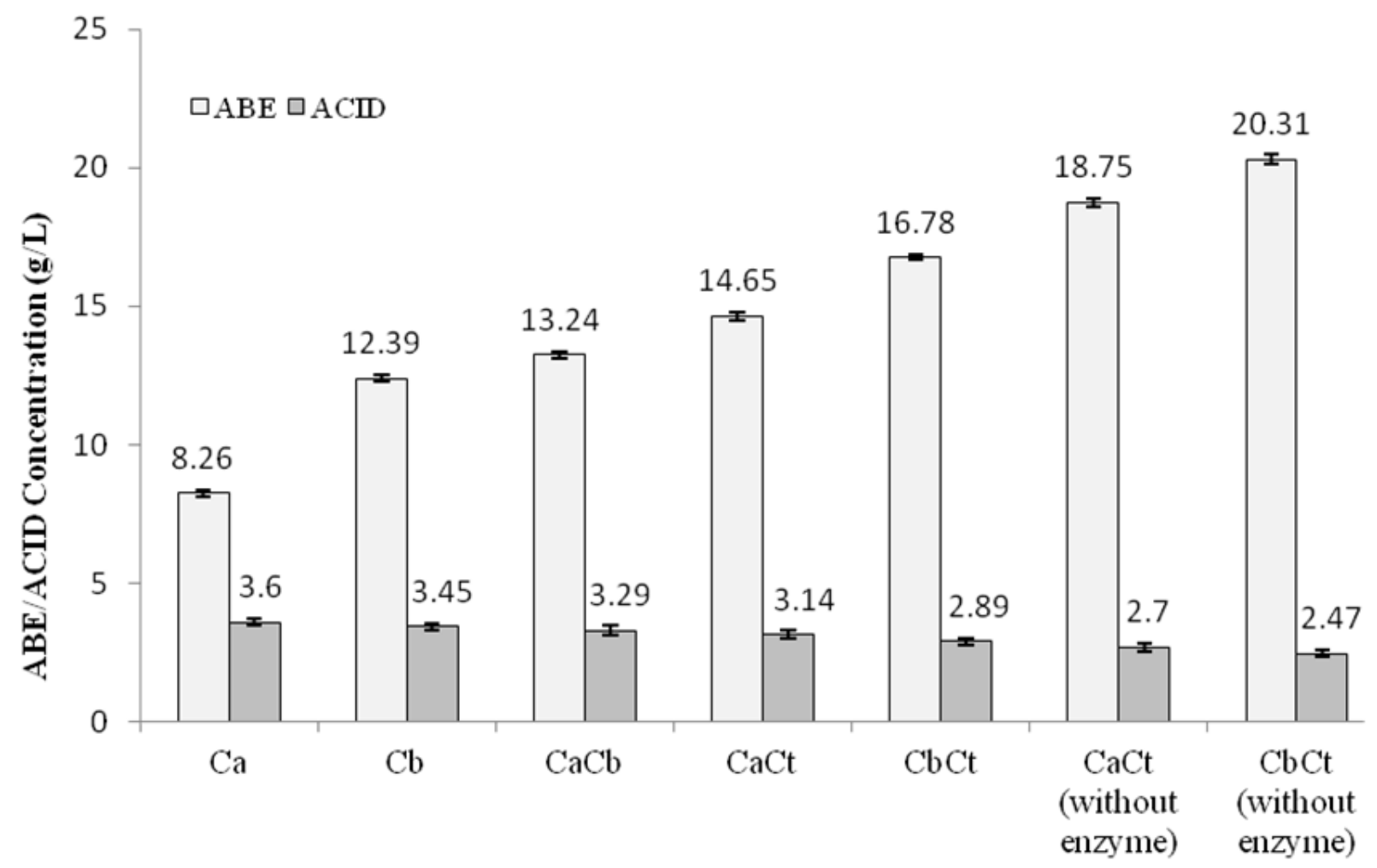

Figure 4.1. Production of AB E and total acids by $\mathrm{Cl}$ ostridium species and its fusants at $35^{\circ} \mathrm{C}$ (Average error percent of ABE and Total acids were found by $1.64 \%$ and $8.33 \%$ respectively; Table A.1) 
As seen in Figure 4.1, comparable increase in the production of ABE was observed with the fused strains of $C a C t$ and $C b C t$ in the presence of hydrolysis enzymes. This increase was accompanied with decrease in acid production (i.e, $14.65 \mathrm{~g} / \mathrm{L}$ and $16.78 \mathrm{~g} / \mathrm{L}$ for $\mathrm{ABE}$, and $3.14 \mathrm{~g} / \mathrm{L}$ and $2.89 \mathrm{~g} / \mathrm{L}$ for acids). Relatively, ABE production using the $C$. beijerinckii fused strain was higher than the corresponding production obtained by $C$. acetobutylicum. This increase in ABE production can be explained based on that the $C$. beijerinckii wild strain generally produces ABE more than by $C$. acetobutylicum [110]. It is also obvious from Figure 4.1 that in the presence of hydrolysis enzymes, $C$. beijerinckii strain produced higher $\mathrm{ABE}$ than $C$. acetobutylicum, while lower amount of acid was produced by the former than the later wild strain. In order to characterize the role of Thermocellum strain in the simultaneous hydrolysis of WS, experiments were conducted using $C$. beijerinckii and $C$. acetobutylicum fused strains in the absence of enzymes (i.e., Celluclast, Novozyme 188 and xylanase). Surprisingly, results in Figure 4.1 showed that in the absence of the hydrolysis enzymes, $C a C t$ and $C b C t$ fused strains produced $18.75 \mathrm{~g} / \mathrm{L}$ and $20.31 \mathrm{~g} / \mathrm{L}$ of $\mathrm{ABE}$ compared to $14.65 \mathrm{~g} / \mathrm{L}$ and $16.78 \mathrm{~g} / \mathrm{L}$ produced in the presence of enzymes, respectively.

Figure 4.2 shows results for the production of $\mathrm{ABE}$ and acids in the $\mathrm{SSF}$ at $45^{\circ} \mathrm{C}$ using the Clostridial fused strains, with and without the addition of enzymes. As shown in this Figure, production of $\mathrm{ABE}$ was improved clearly when compared to the similar fusants in Figure 4.1 at $35^{\circ} \mathrm{C}$. Furthermore, the fused strain $C b C t$ produced higher $\mathrm{ABE}$ at $45^{\circ} \mathrm{C}$ than the $C a C t$ (i.e., $20.93 \mathrm{~g} / \mathrm{L}$ compared to $18.38 \mathrm{~g} / \mathrm{L}$ ), with lower acids production. In the absence of hydrolysis enzymes, ABE production improved as $C b C t$ and $C a C t$ produced $23.88 \mathrm{~g} / \mathrm{L}$ and $21.17 \mathrm{~g} / \mathrm{L} \mathrm{ABE}$, respectively. 


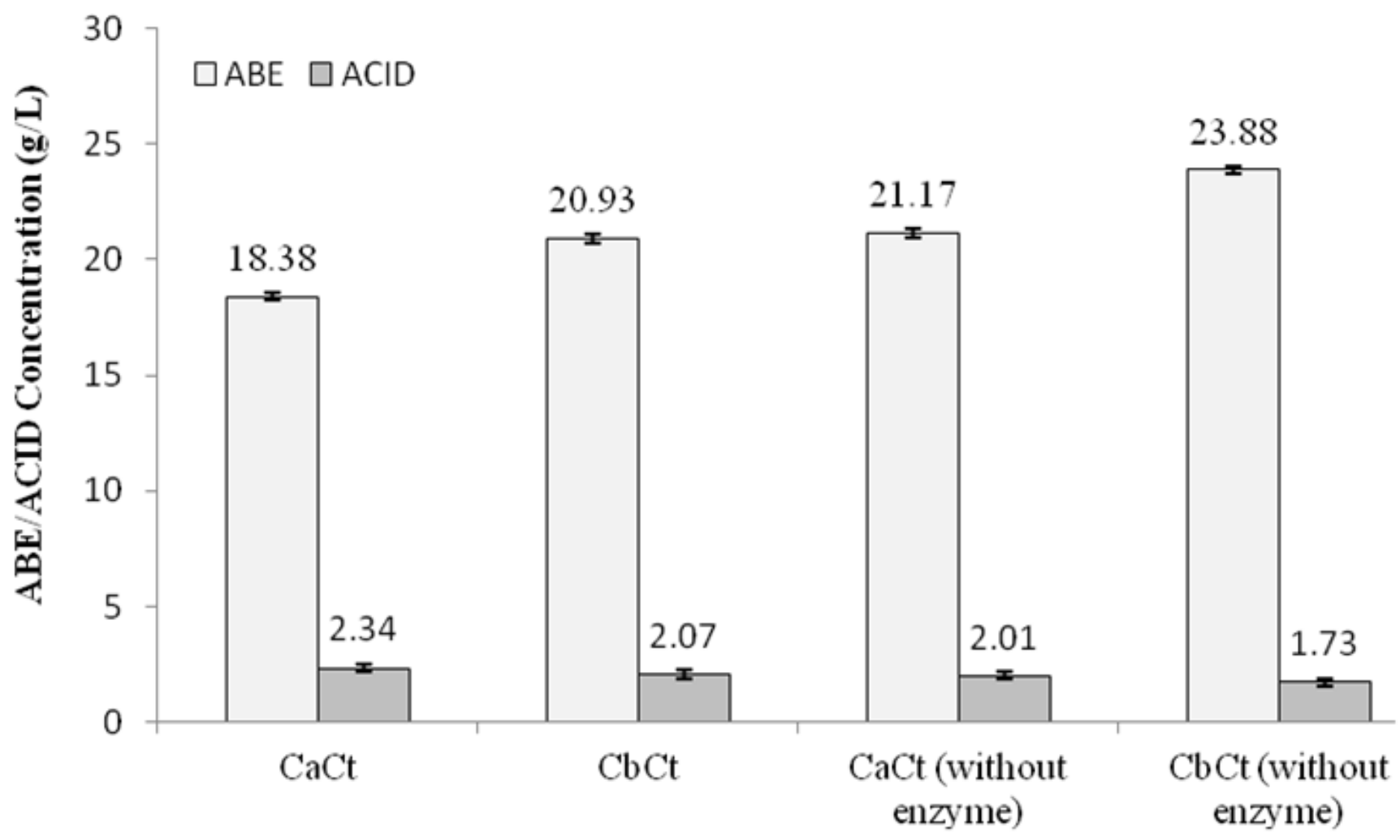

Figure 4.2. Production of $\mathrm{AB}$ E and acids by Clostridium species and its fusants at $45^{\circ} \mathrm{C}$ (Average error percent of ABE and Total acids were found by $1.26 \%$ and $12.38 \%$ respectively; Table A.1)

Furthermore, as shown in Figure 4.1 and Figure 4.2, results demonstrate that fused strains responded more spontaneously at the higher temperature $\left(45^{\circ} \mathrm{C}\right)$ than the lower one $\left(35^{\circ} \mathrm{C}\right)$. This probably can be related to the high sugar production that allows enhancing the production of $\mathrm{ABE}$ (Table 4.2). This clearly demonstrates the thermal stability of the fused strains [111]. In this study, $23.88 \mathrm{~g} / \mathrm{L}$ is the maximum $\mathrm{ABE}$ concentration produced by the fused strain $\mathrm{CbCt}$ (without enzyme) at $45^{\circ} \mathrm{C}$, which is $17.58 \%$ higher than the value found at $35^{\circ} \mathrm{C}$. In general, the higher $\mathrm{ABE}$ production obtained with the $\mathrm{CaCt}$ and $\mathrm{CbCt}$ fused strains in all cases can be linked to the lower acid production. This is clearly obvious at $45^{\circ} \mathrm{C}$ in the absence of enzymes. The higher production in the absence of enzymes can be explained based on that, when enzymes were added, cells preferentially used the exogenous end product, and their own produced enzymes became ceased [112]. Moreover, the 
productions of the three enzymes (endo-exo glucanase, $\beta$-glucosidase) were not interfered with, but action of an additional enzyme was responsible for diminution of butyrate $[113,114]$. Error bars has been displayed on the graphs for $\mathrm{ABE}$ and total acids and the values were measured from the average of three replications.

Table 4.1 lists more details on the individual substances of $\mathrm{ABE}$ and acids that were produced during the SSF experiments by the Clostridia species and its fusants at two different temperatures of $35^{\circ} \mathrm{C}$ and $45^{\circ} \mathrm{C}$ along with the presence and absence of hydrolysis enzymes. During the experimental work in fermentation: acetone, butanol, and ethanol (ABE) were produced in the ratios of 3:6:1 (approximately), with butanol being the major product [6].

Table 4.1. Production of ABE and acids by Clostridium wild and its fusants during the batch SSF experiments at $35^{\circ} \mathrm{C}$ and $45^{\circ} \mathrm{C}$

\begin{tabular}{|c|c|c|c|c|c|}
\hline \multirow{2}{*}{$\begin{array}{c}\text { Clostridium wild and its fused } \\
\text { strains }\end{array}$} & \multicolumn{3}{|c|}{$\operatorname{ABE}(g / L)$} & \multicolumn{2}{|c|}{ Acids (g/L) } \\
\hline & Acetone & Butanol & Ethanol & $\begin{array}{l}\text { Acetic } \\
\text { acid }\end{array}$ & $\begin{array}{c}\text { Buty ric } \\
\text { acid }\end{array}$ \\
\hline \multicolumn{6}{|c|}{$35^{\circ} \mathrm{C}$} \\
\hline $\mathrm{Ca}$ & 2.15 & 5.23 & 0.88 & 2.23 & 1.37 \\
\hline $\mathrm{Cb}$ & 3.81 & 7.36 & 1.21 & 2.16 & 1.29 \\
\hline $\mathrm{CaCb}$ & 3.68 & 8.11 & 1.44 & 2.11 & 1.18 \\
\hline $\mathrm{CaCt}$ & 4.23 & 8.84 & 1.57 & 2.03 & 1.11 \\
\hline $\mathrm{CbCt}$ & 4.8 & 10.19 & 1.78 & 1.92 & 0.97 \\
\hline$C a C t$ (without enzyme) & 6.03 & 11.07 & 1.65 & 1.88 & 0.82 \\
\hline$C b C t$ (without enzyme) & 5.87 & 12.33 & 2.1 & 1.76 & 0.71 \\
\hline \multicolumn{6}{|c|}{$45^{\circ} \mathrm{C}$} \\
\hline $\mathrm{CaCt}$ & 5.37 & 11.22 & 1.79 & 1.69 & 0.65 \\
\hline$C b C t$ & 6.11 & 12.44 & 2.38 & 1.53 & 0.54 \\
\hline $\mathrm{CaCt}$ (without enzyme) & 6.2 & 12.92 & 2.05 & 1.44 & 0.57 \\
\hline$C b C t$ (without enzyme) & 7.31 & 14.13 & 2.43 & 1.24 & 0.49 \\
\hline
\end{tabular}


Examining results in Table 4.1 demonstrates that highest biobutanol production of $15 \mathrm{~g} / \mathrm{L}$ was obtained by $C b C t$ in the absence of the enzymes at the higher temperature of $45^{\circ} \mathrm{C}$. The higher biobutanol production obtained using $C b C t$ than $C a C t$ generally can be related to that $C$. beijerinckii wild strain produces higher biobiotanol than the wild strain of $C$. acetobutylicum at $35^{\circ} \mathrm{C}(7.36 \mathrm{~g} / 1$ compared to $5.23 \mathrm{~g} / \mathrm{L})$. Similarly to the total ABE production, the Clostridial fused strains produced higher biobutanol at $45^{\circ} \mathrm{C}$ than that at $35^{\circ} \mathrm{C}$. This demonstrated the thermal stability of the fused strains at $45^{\circ} \mathrm{C}$. Furthermore, results in Table 4.1 also show the improvement in the production of $\mathrm{ABE}$ in the absence of the hydrolysis enzymes than that in their presence.

\subsection{Biobutanol Production}

Figure 4.3 (a) shows the change in biobutanol production with time at $35^{\circ} \mathrm{C}$ by the wild Clostridial species, its fusant $C a C b$ and the thermostable fusants $C a C t$ and $C b C t$. Examining this Figure shows that production of biobutanol increased gradually per day with similar profiles obtained with all types of strains that were examined over the period of 120 hours of the SSF until no more production was formed. Similar profiles for biobutanol production were obtained at $45^{\circ} \mathrm{C}$ using the different fused strains of bacteria in Table 4.1, as shown in Figure 4.3 (b). Production increased gradually with time for all samples. 

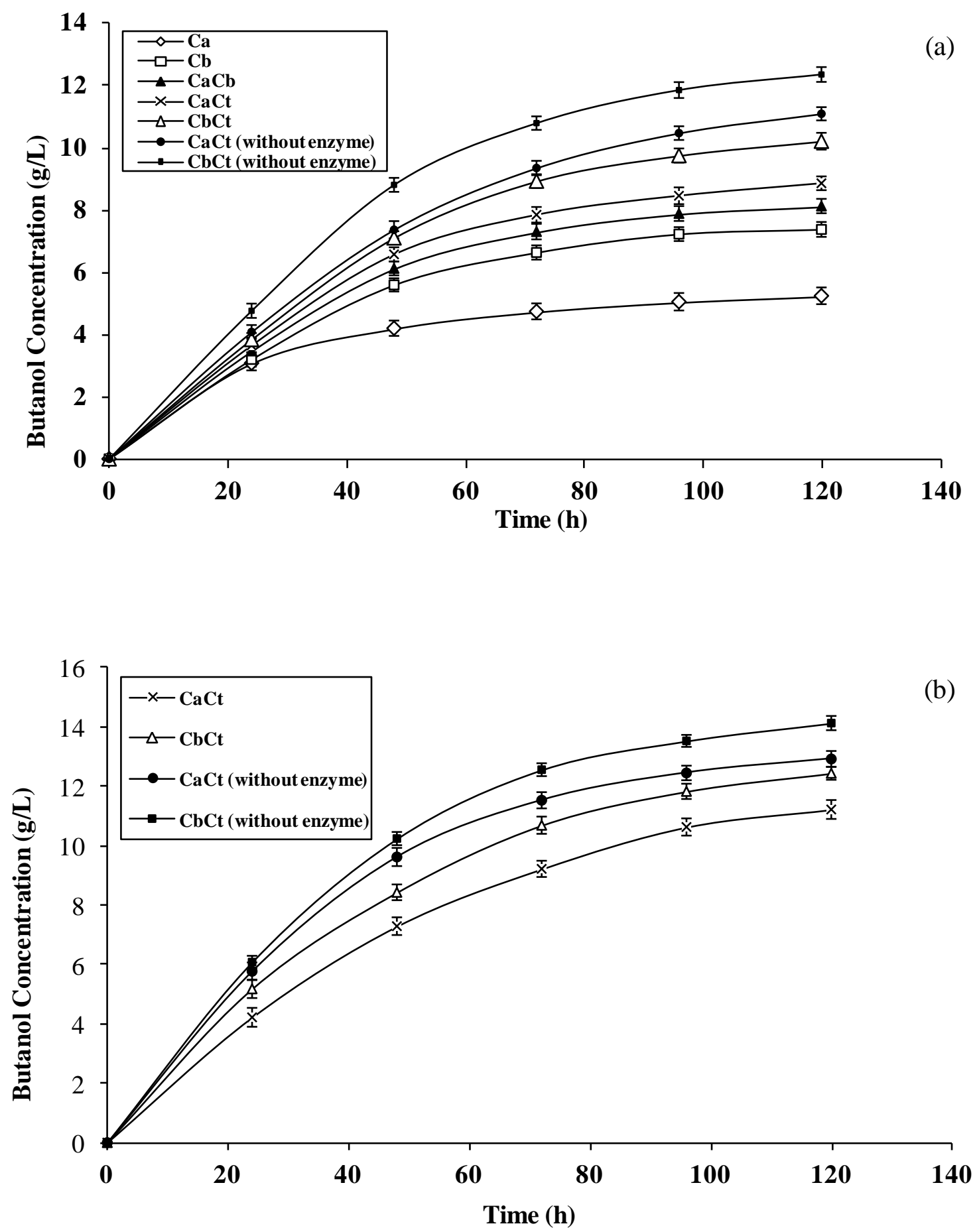

Figure 4.3. Biobutanol production in the batch process using Clostridium species and its fused strains at various SSF times: (a) $35^{\circ} \mathrm{C}$; (b) $45^{\circ} \mathrm{C}$

Figure 4.3 (a) reveals the significant improvement of biobutanol productions that happened for the fused strains compare to the parental strains. It can be seen that after $24 \mathrm{~h}$ of fermentation, fused strains of $\mathrm{CaCt}$ and $\mathrm{CbCt}$ delivered biobutanol production of $3.64 \mathrm{~g} / \mathrm{L}$ and $3.83 \mathrm{~g} / \mathrm{L}$ respectively, which 
were increased to $8.84 \mathrm{~g} / \mathrm{L}$ and $10.19 \mathrm{~g} / \mathrm{L}$ at the end of $120 \mathrm{~h}$ of fermentation. Eventually, fused strains of $\mathrm{CaCt}$ and $\mathrm{CbCt}$ in absence of hydrolysis enzymes delivered comparatively higher values of biobutanol by $11.07 \mathrm{~g} / \mathrm{L}$ and $12.33 \mathrm{~g} / \mathrm{L}$, respectively. Furthermore, Figure 4.3 (b) displays that the biobutanol production profiles were generally more vigorous at $45^{\circ} \mathrm{C}$ than that of $35^{\circ} \mathrm{C}$. Protoplast fused strains of $C b C t$ and $C a C t$ produced biobutanol of $6.08 \mathrm{~g} / \mathrm{L}$ and $5.77 \mathrm{~g} / \mathrm{L}$ after $24 \mathrm{~h}$ of SSF and ended up with production of $12.92 \mathrm{~g} / \mathrm{L}$ and $14.13 \mathrm{~g} / \mathrm{L}$, respectively. Comparatively lower biobutanol production is thought to be a result of poor sugar consumption as well as fewer acids production by the wild strains. These strain characteristics were further improved by generating protoplast fusion strains with the higher capability of sugar uptake, which enhanced production of biobutanol.

In general, comparing Figure 4.3 (a) and (b) demonstrates that production of biobutanol is eventually higher at the high temperature with the fusants. This represents more thermal stability, while production and consumption of sugars at this temperature by the fused strains should also contribute in further interpretation.Moreover, this demonstrates that the Clostridium fused strains are more efficient in hydrolysis of the WS at the higher temperature through producing enzymes during the SSF.

\subsection{Sugar Cons umption}

Table 4.2 showed that $C$. beijerinckii consumed more sugars than $C$. acetobutylicum. Sugars consumption apparently improved with the fused strains. Following that, fused strain $C b C t$ utilized comparatively higher sugars than $\mathrm{CaCt}$. Furthermore, at higher temperature $\left(45^{\circ} \mathrm{C}\right)$, fused strains of $C a C t$ and $C b C t$ produced enhanced biobutanol (Table 4.1) due to its capability of consuming more sugars during solventogenesis phase. It has been reported that $C$. beijerinckii utilizes all the five components of lignocellulosic sugars [113]. In the present study, there were some difficulties to utilize xylose and galactose; that might be due to the metabolism of the culture [see Table 3.4]. However, it is 
important to mention that the capability of solventogenic clostridia efficiently utilizes pentose sugars, including xylose and arabinose in which these sugars are hardly utilized by ethanologenic microorganisms [114]. Table 4.2 displayed individual sugars utilized by the culture. . It was calculated from the individual sugars' concentrations in the wheat straw hydrolysate (see Table 3.4) and the final sugars' concentrations measured by the HPLC.

Table 4.2. Individual sugars' consume d during the $\mathrm{SSF}$ at $35^{\circ} \mathrm{C}$ and $45^{\circ} \mathrm{C}$.

\begin{tabular}{|c|c|c|c|c|c|}
\hline \multirow{2}{*}{$\begin{array}{c}\text { Clostridium strains and its } \\
\text { fusants }\end{array}$} & \multicolumn{5}{|c|}{ Individual sugar cons umed $(\mathrm{g} / \mathrm{L})$ at $35^{\circ} \mathrm{C}$} \\
\hline & Glucose & Xylose & Arabinose & Mannose & Galactose \\
\hline $\mathrm{Ca}$ & 17.2 & 6.24 & 7.22 & 1.6 & 1.02 \\
\hline$C b$ & 17.6 & 7.03 & 7.42 & 1.6 & 1.08 \\
\hline $\mathrm{CaCb}$ & 18.14 & 7.5 & 8.13 & 1.6 & 1.2 \\
\hline $\mathrm{CaCt}$ & 17.36 & 9.13 & 8.35 & 1.6 & 1.02 \\
\hline$C b C t$ & 19.12 & 10.14 & 8.29 & 1.6 & 1.17 \\
\hline$C a C t$ (without enzyme) & 18.39 & 11.53 & 8.25 & 1.6 & 1.21 \\
\hline$C b C t$ (without enzyme) & 20.06 & 11.16 & $8 . .98$ & 1.6 & 1.32 \\
\hline \multicolumn{6}{|c|}{ Individual sugar consumed $(\mathrm{g} / \mathrm{L})$ at $45^{\circ} \mathrm{C}$} \\
\hline $\mathrm{CaCt}$ & 25.19 & 10.22 & 5.5 & 1.6 & 1.15 \\
\hline$C b C t$ & 26.41 & 11.01 & 5.5 & 1.6 & 1.28 \\
\hline$C a C t$ (without enzyme) & 24.96 & 11.32 & 5.5 & 1.6 & 1.24 \\
\hline$C b C t$ (without enzyme) & 27.09 & 12.33 & 5.5 & 1.6 & 1.32 \\
\hline
\end{tabular}

\subsection{Bacterial Cells Growth}

Figure 4.4 (a) and (b) show the changes in bacterial cell concentration with time at two different temperatures of $35^{\circ} \mathrm{C}$ and $45^{\circ} \mathrm{C}$ during the batch SSF experiments. Examining profiles of cell growths 
shows that each strains had a lag phase around $20 \mathrm{~h}$. In the lag phase period, there was a little increase in cell concentration, since there was a period of adaptation to the growth environment, synthesizing enzymes, and developing towards the production stage [115]. Vegetative stage was started at $24 \mathrm{~h}$ (approximately) of SSF experiments This was followed by a decrease in cell count prior to initiating the stationary phase.. In the stationary phase after $96 \mathrm{~h}$ of fermentation, cells reached a minimum biological space where the lack of one or more nutrients limits cell growth. During this phase, the net growth rate is zero, which can be due to the depletion of nutrients and essential metabolites [116].

Bacterial cell concentration increased more rapidly for the fused strains of $\mathrm{CaCt}$ and $\mathrm{CbCt}$ compared to the wild strains of $C a$ and $C b$. This can be related to the total amount of sugars that were consumed during the fermentation, which would lead to higher production and more cell growth. Sugar produced at higher temperature was comparatively high than that of lower one (see Table 3.4). This was due to the difference in enzymatic activity that was measured for the fused strains at two different temperatures (Table 4.4). 

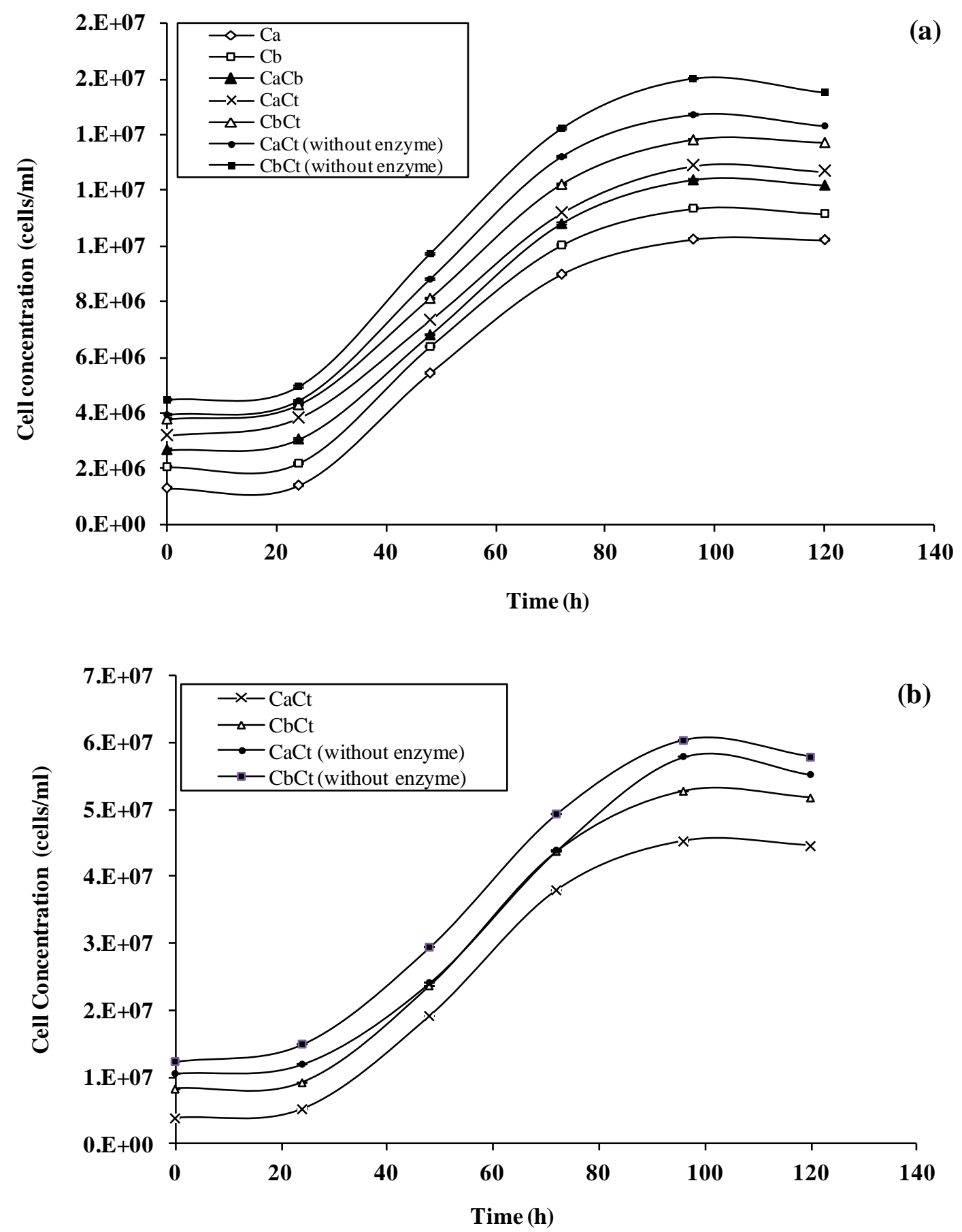

Figure 4.4. Cell growth of Clostridium species during the batch simultaneous saccharification and fermentation at (a) $35^{\circ} \mathrm{C}$ and (b) $45^{\circ} \mathrm{C}$

The different cell growth characteristics for the different strains at $35^{\circ} \mathrm{C}$ and $45^{\circ} \mathrm{C}$ are summarized in Table 4.3. As appears in this Table, cell proliferation rates were calculated based on the 
hourly increase in cell count. Cell proliferation (also known as cell growth, cell division, or cell replication) is the basic process through which cells create new cells [117]. For bacterial cells under èsteady-state exponential growth, the rate of cell proliferation is an important characteristic of the physiological state. The cell proliferation rates of the fused strains were clearly higher than that for the wild strains at temperatures tested. Furthermore, the proliferation rates were further improved for the fused strains at the higher temperature of $45^{\circ} \mathrm{C}$ (i.e., see Figure 3.5. (b)) with higher value for the $C b C t$ than the $\mathrm{CaCt}$. The higher proliferation rates for the fused strains represents boosting in the metabolism of the strain, while this represents thermal stability once marked at the higher temperature of $45^{\circ} \mathrm{C}$.

As shown in Table 4.3, specific cell growth rate of $C b$ was slightly higher than $C a$ may be because of their metabolisms. The specific growth rates of fused strains of $\mathrm{C}$. beijerinckii and $\mathrm{C}$. acetobutylicum without enzymes at $45^{\circ} \mathrm{C}$ were almost identical to that at $35^{\circ} \mathrm{C}$.

Doubling time has been widely used to represent the growth pattern of cells. The doubling times were calculated from Equation (4.1), for all Clostridium strains. Fused strains $C a C t$ and $C b C t$ without addition of hydrolysis enzymes showed almost identical doubling times at higher temperature compare with that of lower one. However, no effect of temperature was clearly marked behind the scene.

$t_{d}=\ln (2) / \mu$ 
Table 4.3. Kinetic parameters for Clostridium species and its fused strains in batch fermentation at $35^{\circ} \mathrm{C}$ and $45^{\circ} \mathrm{C}$

\begin{tabular}{|c|c|c|c|c|c|c|}
\hline Strains & $\begin{array}{l}\text { Specific } \\
\text { growth } \\
\text { rate }\left(h^{-1}\right)^{a}\end{array}$ & $\begin{array}{l}\text { Doubling } \\
\text { time } \\
\text { (h) }{ }^{\text {b }}\end{array}$ & $\begin{array}{c}\text { Cell } \\
\text { Prolife ration } \\
\text { rate } \\
\left(h^{-1}\right)^{\text {c }}\end{array}$ & $\begin{array}{c}\text { Total } \\
\text { Sugar } \\
\text { Cons umed } \\
(\mathrm{g} / \mathrm{L})^{\mathrm{d}}\end{array}$ & $\begin{array}{l}\text { ABE } \\
\text { Yield }^{\mathrm{e}}\end{array}$ & $\begin{array}{c}\text { ABE } \\
\text { Productivity } \\
\text { (g/L.h) }\end{array}$ \\
\hline \multicolumn{7}{|c|}{ Batch Fermentation at $35^{\circ} \mathrm{C}$} \\
\hline $\mathrm{Ca}$ & 0.021 & 32.24 & $1.70 \mathrm{E}+04$ & 33.27 & 0.25 & 0.07 \\
\hline $\mathrm{Cb}$ & 0.022 & 31.79 & $4.80 \mathrm{E}+04$ & 34.72 & 0.35 & 0.10 \\
\hline $\mathrm{CaCb}$ & 0.019 & 37.07 & $7.30 \mathrm{E}+04$ & 36.56 & 0.36 & 0.11 \\
\hline $\mathrm{CaCt}$ & 0.04 & 17.16 & $1.18 \mathrm{E}+05$ & 37.45 & 0.39 & 0.12 \\
\hline$C b C t$ & 0.019 & 36.67 & $1.25 \mathrm{E}+05$ & 40.32 & 0.42 & 0.14 \\
\hline $\begin{array}{c}C a C t \text { (without } \\
\text { enzyme) }\end{array}$ & 0.017 & 40.77 & $1.31 \mathrm{E}+05$ & 40.98 & 0.45 & 0.15 \\
\hline $\begin{array}{c}C b C t \text { (without } \\
\text { enzyme) }\end{array}$ & 0.023 & 30.14 & $1.38 \mathrm{E}+05$ & 43.11 & 0.47 & 0.17 \\
\hline \multicolumn{7}{|c|}{ Batch Fermentation at $45^{\circ} \mathrm{C}$} \\
\hline $\mathrm{CaCt}$ & 0.025 & 27.39 & $3.77 \mathrm{E}+05$ & 44.4 & 0.42 & 0.15 \\
\hline$\overline{C b C t}$ & 0.021 & 32.7 & $6.18 \mathrm{E}+05$ & 46.54 & 0.45 & 0.17 \\
\hline $\begin{array}{c}C a C t \text { (without } \\
\text { enzyme) }\end{array}$ & 0.018 & 38.51 & $4.83 \mathrm{E}+05$ & 45.36 & 0.47 & 0.18 \\
\hline $\begin{array}{c}C b C t \text { (without } \\
\text { enzyme) }\end{array}$ & 0.023 & 30.4 & $7.28 \mathrm{E}+05$ & 48.57 & 0.49 & 0.20 \\
\hline
\end{tabular}

${ }^{a .}$ Calculated from the slope of the graph of ln [dry cell mass $\left.(\mathrm{g} / \mathrm{L})\right]$ versus time $(h)$.

${ }^{b}$. Calculated from $m$ for $t d=\ln (2) / \mu$.

c. Calculated based on the hourly increase in cell count.

${ }^{d}$ Calculated based on the total sugar produced initially of $55.20 \mathrm{~g} / \mathrm{L}$ and $59.59 \mathrm{~g} / \mathrm{L}$ at $35^{\circ} \mathrm{C}$ and $45^{\circ} \mathrm{C}$ respectively (Table 3.4).

${ }^{e}$ ABE yield was calculated based on the total sugar consumed 
Table 4.3 also summarizes that at higher temperature, fusants $\mathrm{CaCt}$ and $\mathrm{CbCt}$ had higher performance in terms of production and growth than that at lower temperature $\left(35^{\circ} \mathrm{C}\right)$. At this high temperature (i.e., $45^{\circ} \mathrm{C}$ ), protoplast fused strains of $\mathrm{CaCt}$ and $\mathrm{CbCt}$ delivered dual activity by producing enzymes and final products (see Table 4.4). Generally, this observed behavior suggests that at the higher temperature, fusants were capable of producing more cells and participated into advanced production of biobutanol. The improvement in the metabolism of the thermally stable fused $C$. beijerinckii can be the reason behind the higher $\mathrm{ABE}$ (i.e., biobutanol) production

One of the important parameters that affect the formation of biobutanol is the $\mathrm{pH}$ condition, and the concentrations of the acids (butyric and acetic) that were produced during the SSF. Throughout the acidogenic phase of growth, the internal $\mathrm{pH}$ decreases in parallel with the decrease in the external $\mathrm{pH}$ due to the formation of acids, but the internal $\mathrm{pH}$ did not go below 5.5 throughout the batch growth [118]. In this study, at the end of fermentation, $\mathrm{pH}$ generally remains between 6.1 and 6.5 . This reflects maintaining $\mathrm{pH}$ during SSF in spite of acid production. This can be explained by that acids were produced during acidogenic stage and utilized during solventogenic phase. Interestingly, furfural inhibitor production during the SSF was quantified between $0.02 \mathrm{~g} / \mathrm{L}$ to $0.03 \mathrm{~g} / \mathrm{L}$ (Table 4.3 ), which apparently should not impact the ABE production process [119]. Moreover, removal of such inhibitor can further improve production of the ABE, which will be the subject of further study in the future.

Examining results for the total sugar consumptions in Table 4.3 it may be deduced that generally the maximum consumption was obtained with the fused strain $C b C t$ at both temperatures tested. The maximum amount of sugar consumption was $82 \%$, which was obtained with the $C b C t$ at $45^{\circ} \mathrm{C}$, while $78 \%$ was obtained at temperature of $35^{\circ} \mathrm{C}$, both without addition of any enzymes. Similarly, higher temperature improved the total amount of sugar consumed for all other fused strains. This can be related to higher metabolic activity observed for all fused strains at higher temperature, 
which is also represented by the higher cell growth rates (Table 4.3). Furthermore, ABE yield was calculated based on the total production with respect to the total sugar consumed. Increasing temperature improved the yield, while maximum yield of 0.49 was obtained with the $C b C t$ fused strain without the addition of enzymes compared to 0.47 with enzymes. This compares with yields of 0.41 and 0.46 obtained with the same strain at $35^{\circ} \mathrm{C}$ with and without the addition of enzymes, respectively.

\subsection{Enzy matic Activity during SSF}

All results above demonstrated that higher biobutanol was obtained with the fused strains without the addition of enzymes. Thermostable enzymes are produced both by thermophilic and mesophilic organisms. Since thermophilic microorganisms are a potential source for thermostable enzymes. Clostridium thermocellum, an anaerobic thermophile that is reported to produce both soluble, cellulose degrading enzymes and celulosomal cellulases, has been a subject of study for decades [102]. According to this, fused strains produced enzymes of endoglucanase, exoglucanase and $\beta$-gluocosidase during the fermentation experiments. In a previous work [reference 112], it was reported that genetically improved strains can produce sufficient amount of enzymes to hydrolyze biomass. Some enzymes are naturally present in the cell but cease to be synthesized because of the high concentrations of their end product are present. Such enzymes are known as repressible enzymes while the end product is called corepressor [112].

In this study, when enzymes were added, cells preferentially used this exogenous end product, and their own produced enzymes became ceased. Moreover, the productions of the three enzymes, endo-exo glucanase, and $\beta$-glucosidase, were not interfered, but action of an additional enzyme was responsible for diminution of butyrate [113, 114]. For this reason, in the current study, from Table 4.4 it was found that enzymatic activity for fused strains with the additional enzymes showed lower values 
than what was obtained without enzymes (51.38 FPU and 52.48 FPU obtained with $\mathrm{CaCt}$ and $\mathrm{CbCt}$ respectively without addition of enzymes compared to 47.44 FPU and 50.34 FPU with the addition of enzymes). Furthermore, fused strains were capable of showing more enzyme activities at higher temperature (59.68 FPU and 61.67 FPU obtained with $C a C t$ and $C b C t$ respectively).

Table 4.4. Enzyme activity of clostridial fused strains in SSF

\begin{tabular}{|c|c|c|}
\hline Clostridium fused strains & $\begin{array}{c}\text { Enzyme Activity at } 35^{\circ} \mathrm{C} \\
\left(\text { FPU }{ }^{*} / \mathrm{mL}\right)\end{array}$ & $\begin{array}{c}\text { Enzyme Activity at } 45^{\circ} \mathrm{C} \\
\left(\text { FPU }^{*} / \mathrm{mL}\right)\end{array}$ \\
\hline $\mathrm{CaCt}$ & 47.44 & 54.09 \\
\hline $\mathrm{CbCt}$ & 50.34 & 56.23 \\
\hline $\mathrm{CaCt}$ (without enzyme) & 51.38 & 59.68 \\
\hline$C b C t$ (without enzyme) & 52.48 & 61.67 \\
\hline
\end{tabular}

FPU is defined as the micromole of glucose equivalent liberated per minute of culture filtrate under assay conditions.

\subsection{Butanol Yield Calculations}

Table 4.5 shows biobutanol yields calculated for different strains with respect to the sugar consumed, and cell production. Protoplast fused strains produced comparatively higher yield of biobutanol at two different temperatures of $35^{\circ} \mathrm{C}$ and $45^{\circ} \mathrm{C}$. C. beijerinckii were capable of producing higher yield of biobutanol than the corresponding C. acetobutylicum ( 0.21 and 0.16 respectively). The increase in biobutanol yield can be explained based on that the $C$. beijerinckii parental strain consumed more sugar than by $C$. acetobutylicum. Fused strains are thermally stable at $45^{\circ} \mathrm{C}$ and gave comparatively higher yield to wild strains ( $\mathrm{CaCt}$ and $\mathrm{CbCt}$ gave yield of 0.28 and 0.29 ). 
Table 4.5. Biobutanol yields of Clostridium species and its fused strains at $35^{\circ} \mathrm{C}$ and $45^{\circ} \mathrm{C}$

\begin{tabular}{|c|c|c|c|c|}
\hline \multirow[b]{2}{*}{ Strain } & \multirow{2}{*}{ Sugar Cons umption (\%) } & \multicolumn{3}{|c|}{ Biobutanol Yield (g/g) } \\
\hline & & $Y_{p / s}^{a}$ & $Y_{p / x}^{b}$ & $Y_{x / s}{ }^{c}$ \\
\hline \multicolumn{5}{|c|}{$35^{\circ} \mathrm{C}$} \\
\hline$C a$ & 60 & 0.16 & 0.15 & 1.05 \\
\hline $\mathrm{Cb}$ & 63 & 0.21 & 0.18 & 1.15 \\
\hline $\mathrm{CaCb}$ & 66 & 0.22 & 0.19 & 1.15 \\
\hline$C a C t$ & 68 & 0.24 & 0.17 & 1.36 \\
\hline$C b C t$ & 73 & 0.25 & 0.16 & 1.61 \\
\hline $\mathrm{CaCt}$ (without enzyme) & 74 & 0.27 & 0.2 & 1.32 \\
\hline$C b C t$ (without enzyme) & 78 & 0.28 & 0.17 & 1.62 \\
\hline \multicolumn{5}{|c|}{$45^{\circ} \mathrm{C}$} \\
\hline $\mathrm{CaCt}$ & 74 & 0.25 & 0.19 & 1.28 \\
\hline$C b C t$ & 78 & 0.26 & 0.16 & 1.68 \\
\hline CaCt (without enzyme) & 76 & 0.28 & 0.22 & 1.3 \\
\hline$C b C t$ (without enzyme) & 82 & 0.29 & 0.17 & 1.75 \\
\hline
\end{tabular}

a. $\mathrm{Yp} / \mathrm{s}(\mathrm{g} / \mathrm{g})=$ butanol produced $(\mathrm{g} / \mathrm{L}) /$ substrate consumed $(\mathrm{g} / \mathrm{L})$

${ }^{b} Y p / x(g / g)=$ butanol produced $(g / L) /$ cell mass formed $(g / L)$

${ }^{c} \mathrm{Yx} / \mathrm{s}(\mathrm{g} / \mathrm{g})=$ cell concentration $(\mathrm{g} / \mathrm{L}) /$ substrate consumed $(\mathrm{g} / \mathrm{L})$

Clostridium fusants $\mathrm{CaCt}$ and $\mathrm{CbCt}$ showed an enhanced biobutanol production in terms of yield coefficients, $Y_{p / s}, Y_{p / x}$ and $Y_{x / s}$ compared to the wild strains are presented in Table 4.5. Breakdown of sugars to pyruvate and utilization of pyruvate requires the induction of enzyme pathways in different ratios. These are: ferredoxin (Feox), phosphotransferase (PTS), acetate kinase (AK) pathways, and thiolase (THL). Mitchell et al. [120] showed that mono and disaccharide uptake occur mainly by the phosphotransferase (PTS) system at various rates, which explains the difference in sugar utilization, 
with galactose being the only sugar to be transported by a non-PTS mechanism. This explains the additional reduction of biobutanol yield compare to other sugars. However, biobutanol yields of fused strains were found higher than the parental strains at $35^{\circ} \mathrm{C}(0.27$ and 0.28 for $\mathrm{CaCt}$ (without enzyme) and $C b C t$ (without enzyme) respectively). Biobutanol yield coefficients of $\left(Y_{p / s}\right.$ and $\left.Y_{x / s}\right) 0.29$ and 1.75 for fusant $C b C t$ (without enzyme) were effectively higher as compared with the other fused strains at $45^{\circ} \mathrm{C}$. Fused strains gave higher sugar consumption, leading to the higher yield of biobutanol.

$\mathrm{ABE}$ yield follows the same trend as biobutanol yield. Wild strains gave lower values of yields to fused strains at $35^{\circ} \mathrm{C}$ (yields of 0.25 and 0.35 were calculated by $C a$ and $C b$ whereas fused strains $C a C t$ (without enzyme) and $C b C t$ (without enzyme) gave yields of 0.45 and 0.47 ). Furthermore, fused strains were produced more $\mathrm{ABE}$ at higher temperature resulting superior values of yield coefficients to lower temperature ( 0.47 and 0.49 for $C a C t$ (without enzyme) and $C b C t$ (without enzyme) respectively). The reason behind the results was enhanced biobutanol production by the fused strains that were found to consume more sugars than the parental strains. Besides, comparatively more sugars were utilized by the fused strains at $45^{\circ} \mathrm{C}$ than $35^{\circ} \mathrm{C}$.

Table 4.6 shows comparison of the present study results with some other research works. Current study results for biobutanol and ABE yields are found 1.63 times and 1.75 times higher than the $C$. beijerinckii 55025 studies by Liu et al. [102]. Results of the current study are also 1.45 times and 1.17 times higher in biobutanol and ABE yields than C. beijerinckii P260 by Qureshi et al. [7]. Moreover, Ezeji et al. [77] used the same C. beijerinckii strain but biobutanol and ABE yield of the current study show 1.12 times and 1.26 times more, respectively. Considering that all studies used for comparison in Table 12 were conducted at larger scale in well-equipped bioreactor, the high potential of further improving the yields of biobutanol and $\mathrm{ABE}$ using the novel Clostridial fused strains is quite clear. More work is to be pursued in this area. 
Table 4.6. Comparison of current research results with the othe $r$ research works

\begin{tabular}{|l|c|c|c|}
\hline \multicolumn{1}{|c|}{ Strain } & $\begin{array}{c}\text { Butanol Yield } \\
(\mathbf{g} / \mathbf{g})\end{array}$ & ABE Yield (g/g) & Reference \\
\hline C. beijerinckii C. thermocellum (fused strain) & 0.29 & 0.49 & Present \\
\hline C. beijerinckii 55025 & & & Study \\
\hline C. beijerinckii P260 & 0.178 & 0.28 & {$[102]$} \\
\hline C. beijerinckii BA101 & 0.2 & 0.42 & {$[7]$} \\
\end{tabular}




\section{CHAPTER 5}

\section{CONCLUSIONS AND RECOMMENDATIONS}

\subsection{Conclusions}

Batch SSF were conducted at two different temperatures to produce biobutanol from WS using Clostridia novel protoplast fused strains in comparison with the Clostridial wild strains. At $35^{\circ} \mathrm{C}$, Clostridia wild strains of $C a, C b$, and their fusants $C a C b, C a C t$ and $C b C t$ produced $5.23 \mathrm{~g} \mathrm{~L}^{-1}, 7.36 \mathrm{~g}$ $\mathrm{L}^{-1}, 8.11 \mathrm{~g} \mathrm{~L}^{-1}, 8.84 \mathrm{~g} \mathrm{~L}^{-1}$ and $10.19 \mathrm{~g} \mathrm{~L}^{-1}$ biobutanol in presence of hydrolysis enzymes. These results are equivalent to biobutanol yields of $0.160 .21,0.22,0.24$ and 0.25 .

Fusants $\mathrm{CaCt}$ and $\mathrm{CbCt}$ were also examined without enzymes at the same temperature and produced $11.07 \mathrm{~g} / \mathrm{L}$ and $12.33 \mathrm{~g} / \mathrm{L}$ biobutanol with yields of 0.27 and 0.28 , respectively. Similarly, at $45^{\circ} \mathrm{C}$ the fusants $C a C t$ and $C b C t$ with enzymes and without addition of enzymes were examined with WS as the feedstock in SSF. These experiments produced $11.22 \mathrm{~g} / \mathrm{L}$ and $12.44 \mathrm{~g} / \mathrm{L}$ (i.e., yields of 0.25 and 0.26 respectively) in the presence of enzymes, whereas in absence of enzymes, strains produced $12.92 \mathrm{~g} / \mathrm{L}$ and $14.13 \mathrm{~g} / \mathrm{L}$ biobutanol (i.e., yields of 0.28 and 0.29 , respectively).

Comparing the production and yields at two different temperatures, the fusant $C b C t$ produced enhanced biobutanol at $45^{\circ} \mathrm{C}$ without enzymes. Apparently, $C b C t$ exhibited dual activity by producing biobutanol in addition to hydrolysis enzymes that are essential to hydrolyze WS effectively into the sugars. In summary, the present study presents this novel fusant of $C b C t$ as a potential strain to enhance production of biobutanol in SSF using WS at higher temperature $\left(45^{\circ} \mathrm{C}\right)$. Enhancement in production is represented by higher production and yield of biobutanol, higher sugar production with the ability to produce hydrolysis enzymes which eliminates the cost associated with saccharification stage. 


\subsection{Recommendations for Future Studies}

In order to further improve the production of biobutanol, Clostridium fused strain $C b C t$ can be used in large scale using bioreactors. Utilizing a well-designed bioreactor will help in limiting the hindrance of butanol production associated with accumulating biobutanol produced concentration through its continuous removal.

Fused strains should be stable during storage and should not be reverted to their original forms, which may occur when taxonomically different species of bacteria undergo the process of fusion. Therefore, the stability of new features after 4, 8, 12 and 24 weeks of storing should be examined by assessing the growing ability of the fused stain in a selection medium.

It is also recommended to check out the stability of the protoplast fused strains by confirming DNA recombination by the comparative analysis of genomic DNA of the parental and fused strains. For the primary stage, stability test through the generation wise can be considered. After inoculation of 2nd, 3rd and 4th generation of fused stains, butanol production can be compared between 1 st and 4th generation. If production of butanol decreases through generation to generation, genetic stability test should be processed before using the fused strains in large scale production. 


\section{REFERENCES}

[1] Dragan Nimcevic and J. Richard Gapes (2000). The Acetone-Butanol fermentation in pilot plant and pre-ind ustrial scale. J. Mol. Microbiol. Biotechnol. 2(1): 15-20.

[2] Zverlov VV, Kellermann J, Schwarz WH (2005). Functional sub genomics of Clostridium thermocellum cellulosomal genes: identification of the major catalytic components in the extracellular complex and detection of three new enzymes. Proteomics 5:3646-3653.

[3] Nasib Qureshi, Peoria, IL, C. Ezeji, Ohio. (2008).. Butanol, 'a superior biofuel' production from agricultural residues (renewable biomass): recent progress in technology. Biofuels. Bioprod. Biorefin. 2:319- 330.

[4] Claassen, P. A. M., J.B. van Lier, A.M.Lopez -Contreras, E.W.J. van Niel, L. Sijtsma, A.J.M. Strams, S.S. de Vries, and R.A. Weusthuis (1999). Utilisation of biomass for the supply of energy carriers. Appl. Microbiol. Biotechnol. 52:741-755.

[5] Marlatt JA, Datta R. (1986). Acetone-butanol fermentation process development and economic evaluation. Biotechnol. Prog. 2:23-8.

[6] Qureshi N, Saha BC, Hector RE, Hughes SR, Cotta MA. (2008). Butanol production from wheat straw by simultaneous saccharification and fermentation using Clostridium beijerinckii: Part I— Batch fermentation. Biomass Bioenergy 32: 168-175.

[7] Qureshi N, Saha BC, Cotta MA. (2007). Butanol production from wheat straw hydrolysate using Clostridium beijerinckii. Bioprocess Biosyst. Eng. 30:419-427.

[8] Food and Agriculture Organization of the United Nations. online/http://www.fao.org/docrep/009/j7927e/j7927e15.htmS, 2006. Retrieved on 2010-0915.

[9] Harper SHT, Lynch JM. (1981). The chemical components and decomposition of wheat straw leaves, internodes and nodes. J. Sci. Food Agric. 32:1057-62. 
[10] Qureshi N, Blaschek HP. (2005). Butanol production from agricultural biomass. Food biotechnol. 2:525-549.

[11] Ezeji TC, Qureshi N, Blaschek HP. (2003). Production of butanol by Clostridium beijerinckii BA101 and in-situ recovery by gas stripping. J. Microbiol. Biotechnol. 19:595-603.

[12] Annous B, Blaschek HP. (1991). Isolation and characterization of Clostridium acetobutylicum mutants with enhanced amylolytic activity. Appl. Environ. Microbiol. $57: 2544-8$.

[13] Lee, S., Park, J., Jang, S., Nielsen, L., Kim, J., \& Jung, K. (2008). Fermentative Butanol Production by Clostridia. Daejeon, Republic of Korea: Biotechnol. and Bioeng. (Vol. 101).

[14] D’Aquino R. (2007). Cellulosic ethanol - Tomorrow's sustainable energy source (Update). Chem. Eng. Prog. 3:8-10.

[15] Anon (2006). The next big thing: biobutanol. Fuels \& Lubes International. Quarter 3:19-22.

[16] Ezeji TC, Qureshi N, Karcher P, Blaschek HP. (2006). Production of butanol from corn. Alcoholic fuels. 99-122.

[17] Sang L, Park J, Jang S, Neilson L, Kim J and Jung K (2008). Fermentative butanol production by Clostridia. Biotechnol. Bioeng. 101(2): 1022-1035.

[18] Jones DT, Woods DR (1986). Acetone-butanol fermentation revisited. Microbiol. Rev. $50: 484-524$.

[19] Ng. T.K., P.J. Weimer, and J.G. Zeikus (1977). Cellulolytic and physiological properties of Clostridium thermocellum. Arch.Microbiol. 114:1-7

[20] Lynd L.R., Willem, H van Zyl., McBride, J.E., \& Mark Laser (2005). Consolidated bioprocessing of cellu losic biomass: an update. Curr. Opin. Biotechnol.16: 577-583.

[21] Demain, A.L. (2009). Biosolutions to the energy problem. J. Ind. Microbiol. Biotechnol. 36: $319-332$.

[22] Saha BC. (2003). Hemicellulose bioconversion. J. Ind. Microbiol. Biotechnol. 30:279-91. 
[23] Ebener J, Qureshi N, Blaschek HP (2003). Corn fiber hydrolysis and fermentation to butanol using Clostridium beijerinckii BA101. In: 25th Biotechnology Symposium for Fuels and Chemicals, Breckenridge, May 4-7.

[24] Ezeji TC, Qureshi N, Blaschek HP (2007). Butanol production from agricultural residues: Impact of degradation products on Clostridium beijerinckii growth and butanol fermentation. Biotechnol. Bioeng. 97: 1460-1469.

[25] Durre P (1998). New insights and novel developments in Clostridial acetone/butanol/isopropanol fermentation. Appl. Microbiol. Biotechnol. 49:639-648.

[26] EIA. Annual energy outlook 1999, with projections to 202. (1998) Energy Information Administration, Department of Energy, Washington, DC, USA.

[27] Raising the profile on Biomass Energy by Ed Munro, posted on July 24th, 2010.

[28] Levin, D.B.; Pitt, L; Love, M. (2004). Biohydrogen production: prospects and limitations to practical application. Int. J. Hydrogen Energy. 29(2): 173-185.

[29] Levin, D.B.; Sparling, R.; Islam, R; Cicek, N. (2006). Hydrogen production y Clostridium thermocellum 27405 from cellulosic biomass substrates. Int. J. Hydrogen Energy. 31(11): 1496-1503.

[30] Lynd, L.R.; van Zyl, W.H.; McBride, L.E.; Laser, M. (2005). Consolidated bioprocessing of cellulosic biomass: an update. Curr. Opin. Biotechnol. 16(5): 577-583.

[31] Lynd, L.R.; Weimer, P.J.; van Zyl, W.H.; Pretorius, I.S. (2002). Microbial cellulose utilization: Fundamentals and biotechnology. Microbiol. Mol. Biol. Rev. 66: 506-577.

[32] Technology Roadmap, Biofuel for Transport, International Energy Agency (IEA). www.iea.org/papers/2011/biofuels-roadmap.pdf

[33] Life cycle assessments applied to first generation biofuels used in France, Final report, February 2010, Direction Production Energies Durables (DEPD) - ADEME. 
[34] Evans, G. "International Biofuels Strategy Project. Liquid Transport Biofuels - Technology Status Report, NNFCC 08-017", National Non-Food Crops Centre, 2008-04-14. Retrieved on 2011-02-16.

[35] Oliver R. Inderwildi, David A. King (2009). "Quo Vadis Biofuels". Energy Environ. Sci. 2: 343.

[36] Eviana Hartman (2008-01-06). "A Promising Oil Alternative: Algae Energy". WashingtonPost.http://www.washingtonpost.com/wpdyn/content/article/2008/01/03/AR2008 010303907.html. Retrieved on 2011-06-20.

[37] astutech ltd / wordserver 2.0. "Globeco biodegradable bio-diesel". Globeco.co.uk. http://www.globeco.co.uk/Biodiesel_news_0007.html. Retrieved on Nov 15, 2010.

[38] "New algal extraction techniques using helix bioreactor." Industrial Bioprocessing (April 3, 2009): NA. GeneralOneFile. Gale.

[39] $\{\mathrm{PhD}$ thesis on algae production for bioenergy $\} "$ (PDF). Murdoch University, WesternAustralia.http://wwwlib.murdoch.edu.au/adt/pubfiles/adt $\quad$ MU20050901. 140745/02Whole.pdf. Retrieved 2008-06-10. Retrieved on 2011-01-22.

[40] Vangrysperre, W., Callens, M., Hilda Kersters-Hilderson, H., \& Clement K. DE Bruyne.(1988). Biochem. J. 250: 153-160.

[41] Greenwell et al (2010) Placing microalgae on the biofuels priority list: a review of the technological challenges. J. R. Soc. Interface May 6, 2010 7: 703-726.

[42] Hartman, Eviana (2008-01-06). "A Promising Oil Alternative: Algae Energy". TheWashingtonPost.http://www.washingtonpost.com/wpdyn/content/article/2008/01/03/AR2 008010303907.html. Retrieved on 2011-01-25.

[43] http://www.ceres.net/AboutUs/About Us-Biofuels-Carbo.html ). Retrieved on Feb 12 , 2011. 
[44] Ennis, B. M.; Maddox, I. S.; Schoutens, G. H. (1986). Immobilized Clostridium acetobutylicum for continuous butanol production from whey permeate. New Zealand J. Dairy Sci. Technol. 21: 99-109.

[45] Formanek, J; Mackie, R; Blaschek, H. P. (1997). Enhanced butanol production by Clostridium bejerinckii BA101 grown in semi defined P2 medium containing 6\% maltodextrin or glucose. Appl. Environ. Microbiol. 63(6): 2306-2310.

[46] www.mashpedia.com/Clostridium. Retrieved on Jan $15^{\text {th }}, 2011$.

[47] Jones, D. T., and D. R. Woods. (1989). Solvent production, p. 105-144. Biotechnology handbook 3.

[48] Rogers, P., and G. Gottschalk. (1993). Biochemistry and regulation of acid and solvent production in clostridia. In: The Clostridia and Biotechnology. D. Woods, eds. ButterworthHeinemann, Stoneham, MA., USA. p. 25-50.

[49] Jones, D. T. and S. Keis. (1995). Origins and relationships of ind ustrial solvent-producing Clostridial strains. FEMS Microbiol. Rev. 17:223-232.

[50] Mitchell, W. J. (1998). Physiology of carbohydrate to solvent conversion by clostridia. Adv. Microb. Physiol. 39:31-130.

[51] Murashima, K.A. Kosugi, and R.H. Doi. (2002). Determination of subunit composition of Clostridium cellulovorans cellulosomes that degrade plant cell walls. Appl. Environ. Microbiol. 68: 1610-1615.

[52] Ladisch, M. R., and J. A. Svarczkopf (1991). Ethanol production and the cost of fermentable sugars from biomass. Bioresour. Technol. 36:83-95.

[53] Girbal L and Soucaille P (1998). Regulation of solvent production in Clostridium acetobutylicum. Trend Biotechnol. 16:11-16.

[54] Peterson, W. H., and E. B. Fred (1932). Butyl-acetone fermentation of corn meal: interrelations of substrate and products. Ind. Eng. Chem. 24:237-242. 
[55] Davies, R., and M. Stephenson (1941). Studies on the acetone butyl alcohol fermentation. Nutritional and other factors involved in the preparation of active suspensions of C. acetobutylicum (Weizmann). Biochem. J. 35:1320-1331.

[56] Jean-Marc Engasser, Fréderic Monot, Henri Petitdemange (1984). Influence of pH and undissociated butyric acid on the production of acetone and butanol in batch cultures of Clostridium acetobutylicum. Appl. Microbiol. Biotechnol. 19: 422-426.

[57] Chen, J.-S., and S. F. Hiu (1986). Acetone-butanol-isopropanol production by Clostridium beijerinckii (synonym, Clostridium butylicum). Biotechnol. Lett. 8:371-376.

[58] Ye Ni and Zhihao Sun (2009). Recent progress on industrial fermentative production of acetone-butanol-ethanol by Clostridium acetobutylicum in China. Appl. Microbiol. Biotechnol. 83:415-423.

[59] Soni B K and Jain M K (1997). Comparison of mutant and parent strains of Clostridium acetobutylicum: butyrate uptake at different temperatures. Bioprocess Eng. 17: 261-276.

[60] Sang L, Park J, Jang S, Neilson L, Kim J and Jung K (2008). Fermentative butanol production by Clostridia. Biotechnol. Bioeng. 101(2): 1022-1035.

[61] Saha, B. C. (2000). a-L-Arabinofuranosidases: biochemistry, molecular biology and application in biotechnology. Biotechnol. Adv. 18:403-423.

[62] Sheehan, J., \& Himmel, M. E. (1999). Enzyme, energy, and the environment: a strategic perspective on the U.S. department of Energy's research and development activities for ethanol. Biotechnol. Prog. 15:817-827.

[63] Mosier, N., Wyman, C., Dale, B., Elander, R., Lee, Y. Y., Holtzapple, M., et al. (2005). Features of promising technologies for pretreatment of lignocellulosic biomass. Bioresour. Technol. 96: 673-686. 
[64] Holtzapple, M. T., Jun, J-H., Ashok, G., Patibandala, S. L., \& Dale, B. E. (1991). The ammonia freeze explosion (AFEX) process: a practical lignocellulose pretreatment. Appl. Biochem. Biotechnol. 28/29: 59-64.

[65] Bjerre, A. B., Olesen, A. B., Fernquist, T., Plöger, A., \& Schmidt, A. S. (1996). Pretreatment of wheat straw using combined wet oxidation and alkaline hydrolysis resulting in convertible cellulose and hemicellulose. Biotechnol. Bioeng. 49: 568-577.

[66] Palmqvist, E., \& Hahn-Hägerdal, B. (2000). Fermentation of lignocellulosic hydrolysates. II: inhibitors and mechanisms of inhibition. Bioresour. Technol. 74:25-33.

[67] Dien, B. S., Jung, H. J. G., Vogel, K. P., Casler, M. D., Lamb, J. F. S., Iten, L., et al. (2006). Chemical composition and response to dilute-acid pretreatment and enzymatic saccharification of alfalfa, reed canarygrass, and switchgrass. Biomass \& Bioenergy, 30: 880-891.

[68] Allen, S. G., Schulman, D., Lichwa, J., Antal, M. J., Laser, M., \& Lynd, L. R. (2001). Ind. Eng. Chem. Res. 40: 2934-2941.

[69] Dien, B. S., Jung, H. J. G., Vogel, K. P., Casler, M. D., Lamb, J. F. S., Iten, L., et al. (2006). Biomass \& Bioenergy, 30, 880-891.

[70] Ezeji T and Blaschek HP (2008). Fermentation of dried distillers'grains and solubles (DDGS) hydrolysates to solvents and value-added products by solventogenic clostridia. Bioresour Technol 99:5232-5242.

[71] Qureshi N (2008). Solvent (acetone-butanol, AB) production. Encyclopedia of Microbiology

[72] Shin K C, Hong B, Fan L T (1983). Fermentive production of Butanol from Sorgham Molasses. Presented at the symposium of Feed, Fuels and Chemicals from Wood and Agricultural Residues. 184th ACS National Meeting, Kansas, MO. Sept 12-17, 1982.

[73] Coughlan, M. P. and Ljungdahl, L. G. (1988). Comparative biochemistry of fungal and bacterial cellulolytic systems. FEMS Symp. 43:11-30. 
[74] Qureshi N, Ebener J, Ezeji TC, Dien B, Cotta MA and Blaschek HP (2007). Butanol production by Clostridium beijerinckii BA101. Part I: Use of acid and enzyme hydrolysed corn fiber. Bioresour Techno1 99:5915-5922.

[75] Mutschlechner O, Swoboda H and Gapes JP (2000). Continuous two-stage ABEfermentation using Clostridium beijerinckii NRRL B592 operating with a growth rate in the first stage vessel close to its maximal value. J Mol. Microbiol Biotechnol 2(1): 101-105.

[76] Hahn-Hagerdal B, Galbe M, Gorwa-Grauslund MF, Liden G and Zacchi G. (2006). Bioethanol- the fuel of tomorrow from the residues of today. Trends Biotechnol. 24(12): $549-556$

[77] Ezeji TC, Qureshi N and Blaschek HP (2004). Acetone-butanol-ethanol production from concentrated substrate: reduction in substrate inhibition by fed-batch technique and product inhibition by gas stripping. Appl. Microbiol. Biotechnol 63:653-658.

[78] Qureshi N and Maddox IS (2005). Reduction in butanol inhibition by perstraction: Utilization of concentrated lactose/whey permeate by Clostridium acetobutylicum to enhance butanol fermentation economics. Official Journal of European Federation of Chem Eng. (formally Trans IChemE): Food Bioprod. Process. 83(C1):43-52.

[79] Qureshi N and Blaschek HP (2001). Evaluation of recent advances in butanol fermentation, upstream, and downstream processing. Bioprocess Biosyst. Eng. 24:219-26.

[80] Qureshi N and Blaschek HP (1999). Butanol recovery from model solutions/fermentation broth by pervaporation: evaluation of membrane performance. Biomass Bioenerg 17:175184.

[81] I.S. Maddox, N. Qureshia and K. Roberts-Thomson (1995). Production of acetone-butanolethanol from concentrated substrate using Clostridium acetobutylicum in an integrated fermentation-product removal process. Process Biochem. 30(3): 209-215. 
[82] Ezeji TC, Qureshi N and Blaschek HP. (2007). Bioproduction of butanol from biomass: From genes to bioreactors. Curr. Opin. Biotechnol. 18:220-227

[83] Mehaia MA and Cheryan M (1986). Lactic acid from acid whey permeate in a membrane recycle bioreactor. Eng. Microbiol. Technol. 8:289-292

[84] Afschar AS, Biebl H, Schaller K and Schugerl K (1985). Production of acetone and butanol by Clostridium acetobutylicum in continuous culture with cell recycle. Appl Microbiol Biotechnol. 22:394-398

Atsumi S, Cann AF, Connor MR, Shen CR, Smith KM, Brynilden MP, Chou KJY, Hanai T and Liao JC. (2008). Metabolic engineering of Escherichia coli for 1-butanol production. Metab. Eng. 6:305-311.

[86] Qureshi, N., \& Blaschek, H. (2000). Butanol production using Clostridium beijerinckii BA101 hyper-butanol producing mutant strain and recovery by pervaporation. Appl. Biochem. Biotechnol. 84: 225-235.

[87] Bowles KL, Bowles WL. Ellefson WL.(1985) Effect of butanol on C. acetobutylicum. Appl Environ Microbiol. 5: 116-121.

[88] Jones, D.T. and D.R. Woods (1986). Acetone-Butanol Fermentation Revisited. Microbiol. Rev. 50: 484-524.

[89] Hotchkiss, R.D. and M.H. Gabor (1980). Biparental products of bacterial protoplast fusion showing unequal parental chromosome expression. Proc. Nat. Acad. Sci. U.S.A. 77: 3553 3557.

[90] Lin, Y. and H.P, Blaschek. (1984). Transformation of heat treated Clostridium acetobutylicum protoplasts with pUBl10 plasmid DNA. Appl. Envir. Microbiol. 48: 737-742.

[91] Gokhale DV, Puntambekar US, Deobagkar DN. (1993). Protoplast fusion: a tool for intergeneric gene transfer in bacteria. Biotechnol. Adv. 11(2):199-217. 
[92] Reilly, P.M. and P. Rogers (1987). Regeneration of cells from protoplasts of Clostridium acetobutylicum B643. J. Ind. Microbiol.1:329 - 334.

[93] Allcock, E.R., S.J. Reid, D.T. Jones and D.R. Woods (1982). Clostridium acetobutylicum protoplast formation and regeneration Appl. Environ. Microbiol. 43:719-721.

[94] G.A. Birrer, W.R. Chesbro and R.M. Zsigray (1989). Protoplast formation, L-colony growth, and regeneration of Clostridium beijerinckii NRRL B-592 and B-593 and Clostridium acetobutylicum ATCC 10132. J. Ind. Microbiol. 4: 325 - 332.

[95] Peberdy, J.F., A.H. Rose, H.J. Rogers and E.C. Cocking, eds. Reversion of protoplasts and L-forms of Bacilli. In: Microbial and Plant Protoplasts. p.201-217,

[96] Greasham, R. and E. Inamine (1986). Nutritional improvement of processes. In: Manual of Industrial Microbiology (A.L. Demain and N.A. Solomon, eds.), pp. 4147, Am. Soc. Microbiol.

[97] Cowling E: Cellulose as a Chemical and Energy Source. (Biotechnol Bioeng Symp.)

[98] Douglas E Eveleigh, Mary Mandels, Raymond Andreotti and Charles Roche. (2009). Measurement of saccharifying cellulose, Biotechnol. Biofuels. 2:21

[99] R. W. O’brien, J. G. Morris ( 1971), Oxygen and the Growth and Metabolism of Clostridium acetobut licum. J. Microbiol. 68: 307-3I8.

[100] Kim, A.Y., Attwood, G.I., White, B.A. and Blaschek, H.P. (1994). Expression of endo- $\beta$-1,4D-glucanase from Clostridium cellulovorans in Clostridium acetobutylicum ATCC824 following transformation of the eng B gene. Appl. Environ. Microbiol. 60:337-340.

[101] Jones, J.D.G., Dunsmuir, P., \& Bedbrook. J. (1985). High levels of expression of introduced chimeric genes in regenerated transformed plants. The EMBO J. 4:2411 -2418.

[102] Liu Ziyong, Yu Ying, Fuli Li, Cuiqing Ma, and Ping Xu (2010). Butanol production by Clostridium beijerinckii ATCC 55025 from wheat bran. J Ind Microbiol Biotechnol 37:4955. 
[103] Ghose TK. 1987. Measurement of cellulase activities. Pure. Appl. Chem. 59:257-268.

[104] Mehdi Dashtban, Miranda Maki, Kam Tin Leung2, Canquan Ma, and Wensheng Qin. (2010). Cellulase activities in biomass conversion: measurement methods and comparison. Biotechnol. 1-8.

[105] B. Adney and J. Baker (1996). Measurement of Cellulase Activitiess. Laboratory Analytical Procedure (LAP). Technical Report NREL/TP-510-42628, January 2008.

[106] Miler GL. (1959). Use of Dintrosalicylic Acid Reagent for Determination of Reducing Sugar. Analyt. Chem. 31:426.

[107] Ratanaporn Leesing, Supaporn Kookkhunthod. (2011). Heterotrophic Growth of Chlorella sp. KKU-S2 for Lipid Production using Molasses as a Carbon Substrate. Food Eng. Biotechnol. 9:87-91.

[108] en.wikipedia.org/wiki/Standard_error. Retrieved on Feb 12 $2^{\text {th }}, 2012$.

[109] David Ramey, Shang-Tian Yang. (2004). Production of Butyric Acid and Butanol from Biomass. US Department of Energy .

[110] J Formanek, R Mackie, H P Blaschek.(1997). Enhanced Butanol Production by Clostridium beijerinckii BA101 Grown in Semidefined P2 Medium Containing 6 Percent Maltodextrin or Glucose. Appl. Environ. Microbiol. 63:2306-2310

[111] Nagamani Balagurusamy. Characterization of thermophilic anaerobic cellulolytic bacteria and their cellulases. Biotechnol. Bioeng.

[112] www.tutorvista.com. Retrieved on 2010-08-10.

[113] H V Kashyap. Advanced Topics in Zoology. (C) Orient Longman Limited 2001, India.

[114] Web Review of Todar's Online Textbook of Bacteriology. "The Good, the Bad, and the Deadly". (SCIENCE Magazine- June 4, 2004 - Vol 304: p. 1421).

[115] Qureshi N, Li X-L, Huges S, Saha BC, Cotta MA. (2006). Butanol production from corn fiber xylan using Clostridium acetobutylycum. Biotechnol Prog. 22: 673-680. 
[116] Andrade, J., and Vasconcelos, I (2003). Continuous cultures of Clostridium acetobutylicum: culture stability and low grade glycerol utilization. Biotechnol. Lett. 25:121-125.

[117] H. Scott Fogler. Essentials of Chemical Reaction Engineering. $4^{\text {th }}$ Ed. Prentice Hall Upper Saddle River, NJ : Prentice Hall PTR, c2006.

[118] Ezeji TC, Qureshi N, Blaschek HP (2007). Butanol production from agricultural residues: impact of degradation products on Clostridium beijerinckii growth and butanol fermention. Biotechnol. Bioeng. 97(6): 1460-1469.

[119] Terracciano, J. S., and E. R. Kashket (1986). Intracellular conditions required for initiation of solvent production by Clostridium acetobutylicum. Appl. Environ. Microbiol. 52:86-91.

[120] Wilfrid J. Michell. (1997). Physiology of Carbohydrate to Solvent Conversion by Clostridia. Adv. Microbial. Physiol. 39:31-130. 


\section{APPENDICES}

Appendix A. Experime ntal data (Raw data)

Table A.1. Production of $\mathrm{ABE}$ and acids by clostridium species and its fusants at $35^{\circ} \mathrm{C}$

\begin{tabular}{|c|c|c|c|c|c|c|c|c|c|c|c|c|}
\hline & \multicolumn{3}{|c|}{$\operatorname{ABE}(g / L)$} & & & & \multicolumn{3}{|c|}{ ACID $(g / L)$} & \multirow[b]{2}{*}{ AVERAGE } & \multirow[b]{2}{*}{ STDEV } & \multirow[b]{2}{*}{ STERROR } \\
\hline & Expt.\# 1 & Expt.\#2 & Expt.\#3 & AVERAGE & STDEV & STERROR & Expt.\#1 & Expt.\#2 & Expt.\#3 & & & \\
\hline $\mathrm{Ca}$ & 8.03 & 8.45 & 8.3 & 8.26 & 0.21 & 0.12 & 3.55 & 3.84 & 3.41 & 3.6 & 0.22 & 0.13 \\
\hline $\mathrm{Cb}$ & 12.58 & 12.17 & 12.42 & 12.39 & 0.21 & 0.12 & 3.33 & 3.33 & 3.69 & 3.45 & 0.21 & 0.12 \\
\hline $\mathrm{CaCb}$ & 13.38 & 12.96 & 13.38 & 13.24 & 0.24 & 0.14 & 3.06 & 3.64 & 3.17 & 3.29 & 0.31 & 0.18 \\
\hline $\mathrm{CaCt}$ & 14.8 & 14.37 & 14.78 & 14.65 & 0.24 & 0.14 & 3.41 & 3.15 & 2.86 & 3.14 & 0.28 & 0.16 \\
\hline $\mathrm{CbCt}$ & 16.57 & 16.86 & 16.91 & 16.78 & 0.18 & 0.11 & 3.18 & 2.72 & 2.77 & 2.89 & 0.25 & 0.15 \\
\hline$C a C t$ (without enzyme) & 18.87 & 18.47 & 18.91 & 18.75 & 0.24 & 0.14 & 2.83 & 2.88 & 2.39 & 2.7 & 0.27 & 0.16 \\
\hline$C b C t$ (without enzy me) & 20.63 & 20.12 & 20.18 & 20.31 & 0.28 & 0.16 & 2.29 & 2.73 & 2.39 & 2.47 & 0.23 & 0.13 \\
\hline
\end{tabular}

Table A.2. Production of ABE and acids by clostridium fused strains at $45^{\circ} \mathrm{C}$

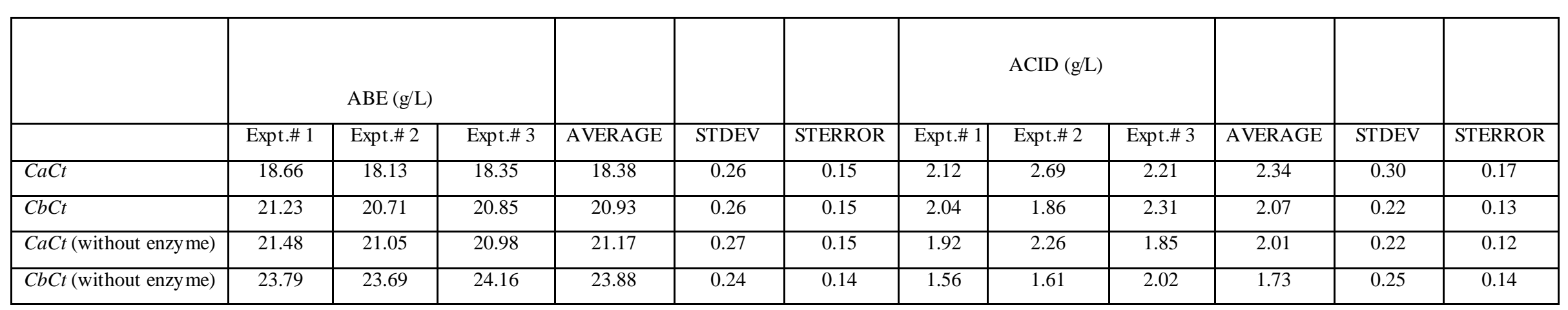


Table A.3. Biobutanol production of $\mathrm{Ca}$ at various SSF times at $35^{\circ} \mathrm{C}$

\begin{tabular}{|c|c|c|c|c|c|c|}
\hline Time (h) & Expt.\#1 & Expt.\#2 & Expt.\#3 & Avg. & \multicolumn{1}{l|}{ STDEV } & STERROR \\
\hline 0 & 0 & 0 & 0 & 0 & 0 & 0 \\
\hline 24 & 3.44 & 3.13 & 2.64 & 3.07 & 0.40 & 0.23 \\
\hline 48 & 3.81 & 4.11 & 4.65 & 4.19 & 0.42 & 0.24 \\
\hline 72 & 4.58 & 4.38 & 5.23 & 4.73 & 0.44 & 0.25 \\
\hline 96 & 4.86 & 4.67 & 5.59 & 5.04 & 0.48 & 0.28 \\
\hline 120 & 4.78 & 5.2 & 5.71 & 5.23 & 0.46 & 0.26 \\
\hline
\end{tabular}

Table A.4. Biobutanol production of $\mathrm{Cb}$ at various SSF times at $35^{\circ} \mathrm{C}$

\begin{tabular}{|c|c|c|c|c|c|c|}
\hline Time (h) & Expt.\#1 & Expt.\#2 & Expt.\#3 & Avg. & STDEV & STERROR \\
\hline 0 & 0 & 0 & 0 & 0 & 0 & 0 \\
\hline 24 & 2.73 & 3.36 & 3.48 & 3.19 & 0.40 & 0.23 \\
\hline 48 & 5.69 & 5.17 & 5.88 & 5.58 & 0.36 & 0.21 \\
\hline 72 & 6.51 & 7.06 & 6.29 & 6.62 & 0.39 & 0.22 \\
\hline 96 & 7.32 & 6.78 & 7.53 & 7.21 & 0.38 & 0.22 \\
\hline 120 & 7.83 & 7.05 & 7.2 & 7.36 & 0.41 & 0.23 \\
\hline
\end{tabular}

Table A.5. Biobutanol production of $\mathrm{CaCb}$ at various SSF times at $35^{\circ} \mathrm{C}$

\begin{tabular}{|c|c|c|c|c|c|c|}
\hline Time (h) & Expt.\#1 & Expt.\#2 & Expt.\#3 & Avg. & STDEV & STERROR \\
\hline 0 & 0 & 0 & 0 & 0 & 0 & 0 \\
\hline 24 & 3.15 & 3.36 & 3.87 & 3.46 & 0.37 & 0.21 \\
\hline 48 & 6.03 & 6.53 & 5.77 & 6.11 & 0.38 & 0.22 \\
\hline 72 & 6.96 & 7.13 & 7.78 & 7.29 & 0.43 & 0.25 \\
\hline 96 & 7.41 & 7.99 & 8.21 & 7.87 & 0.4 & 0.23 \\
\hline 120 & 7.78 & 8.57 & 8.08 & 8.11 & 0.39 & 0.23 \\
\hline
\end{tabular}

Table A.6. Biobutanol production of $\mathrm{CaCt}$ at various SSF times at $35^{\circ} \mathrm{C}$

\begin{tabular}{|c|c|c|c|c|c|c|}
\hline Time (h) & Expt.\#1 & Expt.\#2 & Expt.\#3 & Avg. & STDEV & STERROR \\
\hline 0 & 0 & 0 & 0 & 0 & 0 & 0 \\
\hline 24 & 3.15 & 3.96 & 3.81 & 3.64 & 0.43 & 0.24 \\
\hline 48 & 6.74 & 6.11 & 6.83 & 6.56 & 0.39 & 0.22 \\
\hline 72 & 8.08 & 8.08 & 7.33 & 7.83 & 0.43 & 0.25 \\
\hline 96 & 8.78 & 8.63 & 7.91 & 8.44 & 0.46 & 0.26 \\
\hline 120 & 8.43 & 9.19 & 8.9 & 8.84 & 0.38 & 0.22 \\
\hline
\end{tabular}

Table A.7. Biobutanol production of $\mathrm{CbCt}$ at various $\mathrm{SSF}$ times at $35^{\circ} \mathrm{C}$

\begin{tabular}{|c|c|c|c|c|c|c|}
\hline Time (h) & Expt.\#1 & Expt.\#2 & Expt.\#3 & Avg. & STDEV & STERROR \\
\hline 0 & $\mathbf{0}$ & $\mathbf{0}$ & $\mathbf{0}$ & $\mathbf{0}$ & $\mathbf{0}$ & 0 \\
\hline 24 & 3.46 & 4.17 & 3.86 & 3.83 & 0.35 & 0.20 \\
\hline 48 & 6.74 & 7.47 & 7.06 & 7.09 & 0.36 & 0.21 \\
\hline 72 & 8.51 & 8.95 & 9.27 & 8.91 & 0.38 & 0.22 \\
\hline 96 & 9.45 & 10.18 & 9.56 & 9.73 & 0.39 & 0.22 \\
\hline 120 & 10.14 & 9.75 & 10.68 & 10.19 & 0.46 & 0.26 \\
\hline
\end{tabular}


A.8. Biobutanol production of $\mathrm{CaCt}$ (without enzyme) at various $\mathrm{SSF}$ times at $35^{\circ} \mathrm{C}$

\begin{tabular}{|c|c|c|c|c|c|c|}
\hline Time (h) & Expt.\#1 & Expt.\#2 & Expt.\#3 & Avg. & STDEV & STERROR \\
\hline 0 & 0 & 0 & 0 & 0 & 0 & 0 \\
\hline 24 & 4.07 & 4.45 & 3.68 & 4.07 & 0.38 & 0.22 \\
\hline 48 & 7.28 & 6.91 & 7.86 & 7.35 & 0.47 & 0.27 \\
\hline 72 & 9.07 & 9.13 & 9.79 & 9.33 & 0.39 & 0.23 \\
\hline 96 & 10.38 & 10.11 & 10.86 & 10.45 & 0.37 & 0.21 \\
\hline 120 & 11.46 & 10.73 & 11.02 & 11.07 & 0.36 & 0.21 \\
\hline
\end{tabular}

Table A.9. Biobutanol production of $\mathrm{CbCt}$ (without enzyme) at various SSF times at $35^{\circ} \mathrm{C}$

\begin{tabular}{|c|c|c|c|c|c|c|}
\hline Time (h) & Expt.\#1 & Expt.\#2 & Expt.\#3 & Avg. & STDEV & STERROR \\
\hline 0 & 0 & 0 & 0 & 0 & 0 & 0 \\
\hline 24 & 4.8 & 4.33 & 5.12 & 4.75 & 0.39 & 0.22 \\
\hline 48 & 8.86 & 9.14 & 8.37 & 8.79 & 0.38 & 0.22 \\
\hline 72 & 11.13 & 10.38 & 10.8 & 10.77 & 0.37 & 0.21 \\
\hline 96 & 11.41 & 11.79 & 12.29 & 11.83 & 0.44 & 0.25 \\
\hline 120 & 12.21 & 12.83 & 12.05 & 12.33 & 0.41 & 0.23 \\
\hline
\end{tabular}

Table A.10. Biobutanol production of $\mathrm{CaCt}$ at various SSF times at $45^{\circ} \mathrm{C}$

\begin{tabular}{|c|c|c|c|c|c|c|}
\hline Time (h) & Expt.\#1 & Expt.\#2 & Expt.\#3 & Avg. & STDEV & STERROR \\
\hline 0 & 0 & 0 & 0 & 0 & 0 & 0 \\
\hline 24 & 4.04 & 3.77 & 4.85 & 4.22 & 0.56 & 0.32 \\
\hline 48 & 7.07 & 6.83 & 7.97 & 7.29 & 0.60 & 0.34 \\
\hline 72 & 8.98 & 8.79 & 9.89 & 9.22 & 0.58 & 0.33 \\
\hline 96 & 10.42 & 11.24 & 10.23 & 10.63 & 0.53 & 0.30 \\
\hline 120 & 11.1 & 10.69 & 11.87 & 11.22 & 0.59 & 0.34 \\
\hline
\end{tabular}

Table A.11. Biobutanol production of $\mathrm{CbCt}$ at various $\mathrm{SSF}$ times at $45^{\circ} \mathrm{C}$

\begin{tabular}{|c|c|c|c|c|c|c|}
\hline Time (h) & Expt.\#1 & Expt.\#2 & Expt.\#3 & Avg. & STDEV & STERROR \\
\hline 0 & 0 & 0 & 0 & 0 & 0 & 0 \\
\hline 24 & 5.57 & 5.36 & 4.61 & 5.18 & 0.50 & 0.29 \\
\hline 48 & 8.21 & 8.95 & 8.13 & 8.43 & 0.45 & 0.26 \\
\hline 72 & 10.25 & 10.56 & 11.26 & 10.69 & 0.51 & 0.29 \\
\hline 96 & 11.34 & 12.37 & 11.78 & 11.83 & 0.51 & 0.29 \\
\hline 120 & 12.02 & 12.96 & 12.34 & 12.44 & 0.47 & 0.27 \\
\hline
\end{tabular}

Table A.12. Biobutanol production of $\mathrm{CaCt}$ (without enzyme) at various SSF times at $45^{\circ} \mathrm{C}$

\begin{tabular}{|c|c|c|c|c|c|c|}
\hline Time (h) & Expt.\#1 & Expt.\#2 & Expt.\#3 & Avg. & STDEV & STERROR \\
\hline 0 & 0 & 0 & 0 & 0 & 0 & 0 \\
\hline 24 & 5.17 & 5.87 & 6.27 & 5.77 & 0.55 & 0.32 \\
\hline 48 & 9.21 & 10.11 & 9.54 & 9.62 & 0.45 & 0.26 \\
\hline 72 & 11.44 & 11.02 & 12.13 & 11.53 & 0.56 & 0.32 \\
\hline 96 & 12.41 & 12.03 & 12.91 & 12.45 & 0.44 & 0.25 \\
\hline 120 & 12.86 & 12.42 & 13.48 & 12.92 & 0.53 & 0.30 \\
\hline
\end{tabular}


Table A.13. Biobutanol production of $\mathrm{CbCt}$ (without enzyme) at various $\mathrm{SSF}$ times at $45^{\circ} \mathrm{C}$

\begin{tabular}{|c|c|c|c|c|c|c|}
\hline Time (h) & Expt.\#1 & Expt.\#2 & Expt.\#3 & Avg. & STDEV & STERROR \\
\hline 0 & 0 & 0 & 0 & 0 & 0 & 0 \\
\hline 24 & 6.04 & 5.57 & 6.63 & 6.08 & 0.53 & 0.30 \\
\hline 48 & 10.05 & 10.88 & 9.79 & 10.24 & 0.56 & 0.32 \\
\hline 72 & 12.42 & 12.15 & 13.11 & 12.56 & 0.49 & 0.28 \\
\hline 96 & 13.62 & 13.02 & 13.95 & 13.53 & 0.47 & 0.27 \\
\hline 120 & 14.05 & 13.66 & 14.68 & 14.13 & 0.51 & 0.29 \\
\hline
\end{tabular}

Table A.14. Cell growth of $\mathrm{Ca}$ at $35^{\circ} \mathrm{C}$

\begin{tabular}{|c|c|c|c|c|c|c|}
\hline Time (h) & Expt.\# 1 & Expt. \# 2 & Expt.\# 3 & Avg. & STDEV & STERROR \\
\hline 0 & $1.21 \mathrm{E}+06$ & $1.31 \mathrm{E}+06$ & $1.35 \mathrm{E}+06$ & $1.29 \mathrm{E}+06$ & 72111.03 & 41633.32 \\
\hline 24 & $1.35 \mathrm{E}+06$ & $1.35 \mathrm{E}+06$ & $1.47 \mathrm{E}+06$ & $1.39 \mathrm{E}+06$ & 70104.28 & 40474.72 \\
\hline 48 & $5.49 \mathrm{E}+06$ & $5.37 \mathrm{E}+06$ & $5.41 \mathrm{E}+06$ & $5.42 \mathrm{E}+06$ & 58949.13 & 34034.3 \\
\hline 72 & $8.91 \mathrm{E}+06$ & $8.96 \mathrm{E}+06$ & $9.04 \mathrm{E}+06$ & $8.97 \mathrm{E}+06$ & 63592.45 & 36715.12 \\
\hline 96 & $1.02 \mathrm{E}+07$ & $1.03 \mathrm{E}+07$ & $1.02 \mathrm{E}+07$ & $1.02 \mathrm{E}+07$ & 67815.93 & 39153.54 \\
\hline 120 & $1.02 \mathrm{E}+07$ & $1.03 \mathrm{E}+07$ & $1.02 \mathrm{E}+07$ & $1.02 \mathrm{E}+07$ & 63221.83 & 36501.14 \\
\hline
\end{tabular}

Table A.15. Cell growth of $\mathrm{Cb}$ at $35^{\circ} \mathrm{C}$

\begin{tabular}{|c|c|c|c|c|c|c|}
\hline Time (h) & Expt.\# 1 & Expt.\# 2 & Expt.\# 3 & Avg. & STDEV & STERROR \\
\hline 0 & $1.99 \mathrm{E}+06$ & $2.11 \mathrm{E}+06$ & $2.05 \mathrm{E}+06$ & $2.05 \mathrm{E}+06$ & 60506.2 & 34933.27 \\
\hline 24 & $2.12 \mathrm{E}+06$ & $2.24 \mathrm{E}+06$ & $2.18 \mathrm{E}+06$ & $2.18 \mathrm{E}+06$ & 57558.67 & 33231.51 \\
\hline 48 & $6.34 \mathrm{E}+06$ & $6.43 \mathrm{E}+06$ & $6.34 \mathrm{E}+06$ & $6.37 \mathrm{E}+06$ & 49426.71 & 28536.53 \\
\hline 72 & $1.08 \mathrm{E}+07$ & $1.09 \mathrm{E}+07$ & $1.08 \mathrm{E}+07$ & $1.00 \mathrm{E}+07$ & 56293.87 & 32501.28 \\
\hline 96 & $1.23 \mathrm{E}+07$ & $1.24 \mathrm{E}+07$ & $1.23 \mathrm{E}+07$ & $1.13 \mathrm{E}+07$ & 74054.03 & 42755.12 \\
\hline 120 & $7.13 \mathrm{E}+06$ & $7.12 \mathrm{E}+06$ & $7.20 \mathrm{E}+06$ & $1.12 \mathrm{E}+07$ & 45923.85 & 26514.15 \\
\hline
\end{tabular}

Table A.16. Cell growth of $\mathrm{CaCb}$ at $35^{\circ} \mathrm{C}$

\begin{tabular}{|c|c|c|c|c|c|c|}
\hline Time (h) & Expt.\# 1 & Expt.\# 2 & Expt.\# 3 & Avg. & STDEV & STERROR \\
\hline 0 & $2.62 \mathrm{E}+06$ & $2.75 \mathrm{E}+06$ & $2.65 \mathrm{E}+06$ & $2.67 \mathrm{E}+06$ & 67290.42 & 38850.14 \\
\hline 24 & $3.01 \mathrm{E}+06$ & $3.12 \mathrm{E}+06$ & $3.02 \mathrm{E}+06$ & $3.05 \mathrm{E}+06$ & 62425.96 & 36041.64 \\
\hline 48 & $6.74 \mathrm{E}+06$ & $6.83 \mathrm{E}+06$ & $6.80 \mathrm{E}+06$ & $6.79 \mathrm{E}+06$ & 45530.21 & 26286.88 \\
\hline 72 & $1.15 \mathrm{E}+07$ & $1.16 \mathrm{E}+07$ & $1.14 \mathrm{E}+07$ & $1.08 \mathrm{E}+07$ & 68563.84 & 39585.35 \\
\hline 96 & $1.23 \mathrm{E}+07$ & $1.24 \mathrm{E}+07$ & $1.23 \mathrm{E}+07$ & $1.24 \mathrm{E}+07$ & 58229.95 & 33619.08 \\
\hline 120 & $1.21 \mathrm{E}+07$ & $1.22 \mathrm{E}+07$ & $1.22 \mathrm{E}+07$ & $1.22 \mathrm{E}+07$ & 46810.1 & 27025.83 \\
\hline
\end{tabular}

Table A.17. Cell growth of $\mathrm{CaCt}$ at $35^{\circ} \mathrm{C}$

\begin{tabular}{|c|c|c|c|c|c|c|}
\hline Time (h) & Expt.\# 1 & Expt.\# 2 & Expt.\# 3 & Avg. & STDEV & STERROR \\
\hline 0 & $3.14 \mathrm{E}+06$ & $3.24 \mathrm{E}+06$ & $3.19 \mathrm{E}+06$ & $3.19 \mathrm{E}+06$ & 49689.03 & 28687.98 \\
\hline 24 & $3.88 \mathrm{E}+06$ & $3.77 \mathrm{E}+06$ & $3.81 \mathrm{E}+06$ & $3.82 \mathrm{E}+06$ & 52808.05 & 30488.74 \\
\hline 48 & $7.38 \mathrm{E}+06$ & $7.28 \mathrm{E}+06$ & $7.33 \mathrm{E}+06$ & $7.33 \mathrm{E}+06$ & 47439.77 & 27389.36 \\
\hline 72 & $1.18 \mathrm{E}+07$ & $1.19 \mathrm{E}+07$ & $1.19 \mathrm{E}+07$ & $1.12 \mathrm{E}+07$ & 45905.18 & 26503.37 \\
\hline 96 & $1.29 \mathrm{E}+07$ & $1.29 \mathrm{E}+07$ & $1.29 \mathrm{E}+07$ & $1.29 \mathrm{E}+07$ & 49789.56 & 28746.01 \\
\hline 120 & $1.27 \mathrm{E}+07$ & $1.26 \mathrm{E}+07$ & $1.27 \mathrm{E}+07$ & $1.27 \mathrm{E}+07$ & 46808.12 & 27024.68 \\
\hline
\end{tabular}


Table A.18. Cell growth of $\mathrm{CbCt}$ at $35^{\circ} \mathrm{C}$

\begin{tabular}{|c|c|c|c|c|c|c|}
\hline Time (h) & Expt.\# 1 & Expt.\# 2 & Expt.\# 3 & Avg. & STDEV & STERROR \\
\hline 0 & $3.71 \mathrm{E}+06$ & $3.81 \mathrm{E}+06$ & $3.79 \mathrm{E}+06$ & $3.77 \mathrm{E}+06$ & 50089.92 & 28919.43 \\
\hline 24 & $4.23 \mathrm{E}+06$ & $4.34 \mathrm{E}+06$ & $4.27 \mathrm{E}+06$ & $4.28 \mathrm{E}+06$ & 51318.93 & 29629 \\
\hline 48 & $8.05 \mathrm{E}+06$ & $8.15 \mathrm{E}+06$ & $8.10 \mathrm{E}+06$ & $8.10 \mathrm{E}+06$ & 49339.59 & 28486.23 \\
\hline 72 & $1.33 \mathrm{E}+07$ & $1.33 \mathrm{E}+07$ & $1.33 \mathrm{E}+07$ & $1.22 \mathrm{E}+07$ & 47610.83 & 27488.13 \\
\hline 96 & $1.38 \mathrm{E}+07$ & $1.38 \mathrm{E}+07$ & $1.38 \mathrm{E}+07$ & $1.38 \mathrm{E}+07$ & 46292.55 & 26727.02 \\
\hline 120 & $1.38 \mathrm{E}+07$ & $1.37 \mathrm{E}+07$ & $1.37 \mathrm{E}+07$ & $1.37 \mathrm{E}+07$ & 48280.43 & 27874.72 \\
\hline
\end{tabular}

Table A.19. Cell growth of $\mathrm{CaCt}$ (without enzyme) at $35^{\circ} \mathrm{C}$

\begin{tabular}{|c|c|c|c|c|c|c|}
\hline Time (h) & Expt. \# 1 & Expt.\# 2 & Expt. \# 3 & Avg. & STDEV & STERROR \\
\hline 0 & $3.88 \mathrm{E}+06$ & $3.98 \mathrm{E}+06$ & $3.91 \mathrm{E}+06$ & $3.92 \mathrm{E}+06$ & 52144.03 & 30105.37 \\
\hline 24 & $4.48 \mathrm{E}+06$ & $4.37 \mathrm{E}+06$ & $4.40 \mathrm{E}+06$ & $4.42 \mathrm{E}+06$ & 57966.28 & 33466.85 \\
\hline 48 & $8.74 \mathrm{E}+06$ & $8.86 \mathrm{E}+06$ & $8.78 \mathrm{E}+06$ & $8.79 \mathrm{E}+06$ & 60555.76 & 34961.88 \\
\hline 72 & $1.31 \mathrm{E}+07$ & $1.32 \mathrm{E}+07$ & $1.32 \mathrm{E}+07$ & $1.32 \mathrm{E}+07$ & 53113.09 & 30664.86 \\
\hline 96 & $1.48 \mathrm{E}+07$ & $1.47 \mathrm{E}+07$ & $1.46 \mathrm{E}+07$ & $1.47 \mathrm{E}+07$ & 63529.52 & 36678.79 \\
\hline 120 & $1.43 \mathrm{E}+07$ & $1.44 \mathrm{E}+07$ & $1.43 \mathrm{E}+07$ & $1.43 \mathrm{E}+07$ & 46508.06 & 26851.44 \\
\hline
\end{tabular}

Table A.20. Cell growth of $\mathrm{CbCt}$ (without enzyme) at $35^{\circ} \mathrm{C}$

\begin{tabular}{|c|c|c|c|c|c|c|}
\hline Time (h) & Expt.\# 1 & Expt.\# 2 & Expt. \# 3 & Avg. & STDEV & STERROR \\
\hline 0 & $4.42 \mathrm{E}+06$ & $4.53 \mathrm{E}+06$ & $4.43 \mathrm{E}+06$ & $4.46 \mathrm{E}+06$ & 58197.94 & 33600.6 \\
\hline 24 & $4.89 \mathrm{E}+06$ & $5.02 \mathrm{E}+06$ & $4.91 \mathrm{E}+06$ & $4.93 \mathrm{E}+06$ & 71601.43 & 41339.11 \\
\hline 48 & $9.63 \mathrm{E}+06$ & $9.72 \mathrm{E}+06$ & $9.75 \mathrm{E}+06$ & $9.70 \mathrm{E}+06$ & 62960.3 & 36350.15 \\
\hline 72 & $1.42 \mathrm{E}+07$ & $1.43 \mathrm{E}+07$ & $1.42 \mathrm{E}+07$ & $1.42 \mathrm{E}+07$ & 59908.26 & 34588.05 \\
\hline 96 & $1.74 \mathrm{E}+07$ & $1.73 \mathrm{E}+07$ & $1.73 \mathrm{E}+07$ & $1.60 \mathrm{E}+07$ & 44237.99 & 25540.82 \\
\hline 120 & $1.55 \mathrm{E}+07$ & $1.55 \mathrm{E}+07$ & $1.55 \mathrm{E}+07$ & $1.55 \mathrm{E}+07$ & 38223.03 & 22068.08 \\
\hline
\end{tabular}

Table A.21. Cell growth of $\mathrm{CaCt}$ at $45^{\circ} \mathrm{C}$

\begin{tabular}{|c|c|c|c|c|c|c|}
\hline Time (h) & Expt.\# 1 & Expt.\# 2 & Expt.\# 3 & Avg. & STDEV & STERROR \\
\hline 0 & $3.85 \mathrm{E}+06$ & $3.75 \mathrm{E}+06$ & $3.80 \mathrm{E}+06$ & $3.80 \mathrm{E}+06$ & 47507.89 & 27428.7 \\
\hline 24 & $5.14 \mathrm{E}+06$ & $5.13 \mathrm{E}+06$ & $5.24 \mathrm{E}+06$ & $5.17 \mathrm{E}+06$ & 59949.62 & 34611.93 \\
\hline 48 & $1.91 \mathrm{E}+07$ & $1.91 \mathrm{E}+07$ & $1.92 \mathrm{E}+07$ & $1.91 \mathrm{E}+07$ & 51029.4 & 29461.84 \\
\hline 72 & $3.79 \mathrm{E}+07$ & $3.79 \mathrm{E}+07$ & $3.80 \mathrm{E}+07$ & $3.79 \mathrm{E}+07$ & 48135.23 & 27790.89 \\
\hline 96 & $4.52 \mathrm{E}+07$ & $4.53 \mathrm{E}+07$ & $4.52 \mathrm{E}+07$ & $4.52 \mathrm{E}+07$ & 52048.05 & 30049.96 \\
\hline 120 & $4.46 \mathrm{E}+07$ & $4.45 \mathrm{E}+07$ & $4.45 \mathrm{E}+07$ & $4.45 \mathrm{E}+07$ & 62361.85 & 36004.63 \\
\hline
\end{tabular}

Table A.22. Cell growth of $\mathrm{CbCt}$ at $45^{\circ} \mathrm{C}$

\begin{tabular}{|c|c|c|c|c|c|c|}
\hline Time (h) & Expt.\# 1 & Expt.\# 2 & Expt.\# 3 & Avg. & STDEV & STERROR \\
\hline 0 & $1.02 \mathrm{E}+07$ & $1.03 \mathrm{E}+07$ & $1.03 \mathrm{E}+07$ & 10290000 & 42225.58 & 24378.95 \\
\hline 24 & $3.23 \mathrm{E}+07$ & $3.23 \mathrm{E}+07$ & $3.23 \mathrm{E}+07$ & 32300000 & 36592.35 & 21126.6 \\
\hline 48 & $4.05 \mathrm{E}+07$ & $4.06 \mathrm{E}+07$ & $4.03 \mathrm{E}+07$ & 40500000 & 148697.7 & 85850.65 \\
\hline 72 & $4.77 \mathrm{E}+07$ & $4.77 \mathrm{E}+07$ & $4.77 \mathrm{E}+07$ & 47700000 & 33719.43 & 19467.92 \\
\hline 96 & $7.42 \mathrm{E}+07$ & $7.43 \mathrm{E}+07$ & $7.42 \mathrm{E}+07$ & 74200000 & 46357.31 & 26764.4 \\
\hline 120 & $5.57 \mathrm{E}+07$ & $5.57 \mathrm{E}+07$ & $5.57 \mathrm{E}+07$ & 55700000 & 28618.18 & 16522.71 \\
\hline
\end{tabular}


Table A.23. Cell growth of $\mathrm{CaCt}$ (without enzyme) at $45^{\circ} \mathrm{C}$

\begin{tabular}{|c|c|c|c|c|c|c|}
\hline Time (h) & Expt.\# 1 & Expt.\# 2 & Expt.\# 3 & Avg. & STDEV & STERROR \\
\hline 0 & $1.15 \mathrm{E}+07$ & $1.15 \mathrm{E}+07$ & $1.15 \mathrm{E}+07$ & 11500000 & 37643.06 & 21733.23 \\
\hline 24 & $1.69 \mathrm{E}+07$ & $1.69 \mathrm{E}+07$ & $1.69 \mathrm{E}+07$ & 16900000 & 37027.02 & 21377.56 \\
\hline 48 & $2.11 \mathrm{E}+07$ & $2.12 \mathrm{E}+07$ & $2.11 \mathrm{E}+07$ & 21100000 & 56956.12 & 32883.63 \\
\hline 72 & $3.19 \mathrm{E}+07$ & $3.19 \mathrm{E}+07$ & $3.19 \mathrm{E}+07$ & 31900000 & 30512.29 & 17616.28 \\
\hline 96 & $5.79 \mathrm{E}+07$ & $5.79 \mathrm{E}+07$ & $5.79 \mathrm{E}+07$ & 57900000 & 31575.31 & 18230.01 \\
\hline 120 & $4.82 \mathrm{E}+07$ & $4.82 \mathrm{E}+07$ & $4.82 \mathrm{E}+07$ & 48200000 & 42320.21 & 24433.58 \\
\hline
\end{tabular}

Table A.24. Cell growth of $\mathrm{CbCt}$ (without enzyme) at $45^{\circ} \mathrm{C}$

\begin{tabular}{|c|c|c|c|c|c|c|}
\hline Time (h) & Expt.\# 1 & Expt. \# 2 & Expt. \# 3 & Avg. & STDEV & STERROR \\
\hline 0 & $1.03 \mathrm{E}+07$ & $1.03 \mathrm{E}+07$ & $1.03 \mathrm{E}+07$ & 10300000 & 34117.44 & 19697.72 \\
\hline 24 & $2.69 \mathrm{E}+07$ & $2.69 \mathrm{E}+07$ & $2.69 \mathrm{E}+07$ & 26900000 & 39357.34 & 22722.97 \\
\hline 48 & $3.27 \mathrm{E}+07$ & $3.27 \mathrm{E}+07$ & $3.27 \mathrm{E}+07$ & 32700000 & 30315.01 & 17502.38 \\
\hline 72 & $4.13 \mathrm{E}+07$ & $4.13 \mathrm{E}+07$ & $4.13 \mathrm{E}+07$ & 41300000 & 29103.26 & 16802.78 \\
\hline 96 & $8.72 \mathrm{E}+07$ & $8.73 \mathrm{E}+07$ & $8.73 \mathrm{E}+07$ & 87300000 & 54064.78 & 31214.31 \\
\hline 120 & $5.28 \mathrm{E}+07$ & $5.28 \mathrm{E}+07$ & $5.28 \mathrm{E}+07$ & 52800000 & 41868.84 & 24172.99 \\
\hline
\end{tabular}

Table A.25. Dry mass of clostridium s pecies and its fused strains to calculate S pecific growth rate at $35^{\circ} \mathrm{C}$

\begin{tabular}{|c|c|c|c|c|c|c|c|c|}
\hline & $\boldsymbol{C a} \boldsymbol{C t}$ & $\boldsymbol{C b C t}$ & $\boldsymbol{C a}$ & $\boldsymbol{C b}$ & $\boldsymbol{C a} \boldsymbol{C b}$ & $\boldsymbol{C a C t}$ (without enzyme) & $\boldsymbol{C b C t}$ (without enz yme) \\
\hline Time (h) & \multicolumn{7}{|c|}{ Cell Concentration (g/L) } \\
\hline 0 & $2.96 \mathrm{E}-02$ & $3.58 \mathrm{E}-01$ & $7.84 \mathrm{E}-01$ & 0.22 & $1.91 \mathrm{E}-01$ & $3.51 \mathrm{E}-01$ & 0.23 \\
\hline 24 & $1.65 \mathrm{E}+00$ & $2.31 \mathrm{E}+00$ & $2.17 \mathrm{E}+00$ & 1.98 & $2.15 \mathrm{E}+00$ & 2.430098 & 2.73 \\
\hline 48 & $2.99 \mathrm{E}+00$ & $3.12 \mathrm{E}+00$ & $2.80 \mathrm{E}+00$ & 2.6 & $2.84 \mathrm{E}+00$ & 3.068983 & 3.45 \\
\hline 72 & $3.59 \mathrm{E}+00$ & $3.66 \mathrm{E}+00$ & $3.20 \mathrm{E}+00$ & 3.04 & $3.25 \mathrm{E}+00$ & $3.25 \mathrm{E}+00$ & 3.83 \\
\hline 96 & $3.74 \mathrm{E}+00$ & $3.92 \mathrm{E}+00$ & $3.41 \mathrm{E}+00$ & 3.57 & $3.50 \mathrm{E}+00$ & $3.72 \mathrm{E}+00$ & 4.00 \\
\hline 120 & $3.93 \mathrm{E}+00$ & $4.17 \mathrm{E}+00$ & $3.56 \mathrm{E}+00$ & 3.69 & $3.74 \mathrm{E}+00$ & $3.99 \mathrm{E}+00$ & 4.24 \\
\hline
\end{tabular}

Table A.26. Dry mass of clostridi um fused strains to calculate specific growth $r$ ate $a 5^{\circ} \mathrm{C}$

\begin{tabular}{|c|c|c|c|c|}
\hline & $\boldsymbol{C a C t}$ & $\boldsymbol{C b C t}$ & $\boldsymbol{C a C t}$ (without enzyme) & $\boldsymbol{C b C t}$ (without enzyme) \\
\hline Time (h) & \multicolumn{3}{|c|}{ Cell Concentration (g/L) } \\
\hline 0 & $8.54 \mathrm{E}-01$ & $1.40 \mathrm{E}-01$ & $3.29 \mathrm{E}-01$ & 0.35 \\
\hline 24 & $2.48 \mathrm{E}+00$ & $2.74 \mathrm{E}+00$ & 2.396985768 & 2.79 \\
\hline 48 & $2.92 \mathrm{E}+00$ & $3.49 \mathrm{E}+00$ & 3.220075105 & 3.37 \\
\hline 72 & $3.35 \mathrm{E}+00$ & $3.84 \mathrm{E}+00$ & $3.61 \mathrm{E}+00$ & 3.81 \\
\hline 96 & $3.74 \mathrm{E}+00$ & $4.17 \mathrm{E}+00$ & $3.84 \mathrm{E}+00$ & 4.08 \\
\hline 120 & $4.08 \mathrm{E}+00$ & $4.45 \mathrm{E}+00$ & $4.04 \mathrm{E}+00$ & 4.35 \\
\hline
\end{tabular}

Table A.27. Dilution of glucose standards and UV/VIS s pectrophotometer reading

\begin{tabular}{|c|c|c|c|c|}
\hline Glucose stock $(\mathbf{m L})$ & Citrate buffer $(\mathbf{m L})$ & Dilution & Concentration & Abs.540 nm \\
\hline 1 & 0.5 & $01: 01.5$ & $3.35 \mathrm{mg} / 0.5 \mathrm{~mL}$ & 0.765 \\
\hline 2 & 1 & $1: 02$ & $2.50 \mathrm{mg} / 0.5 \mathrm{~mL}$ & 0.579 \\
\hline 3 & 2 & $1: 03$ & $1.65 \mathrm{mg} / 0.5 \mathrm{~mL}$ & 0.384 \\
\hline 4 & 4 & $1: 05$ & $1.00 \mathrm{mg} / 0.5 \mathrm{~mL}$ & 0.22 \\
\hline
\end{tabular}

Table A.28. Enzyme dilutions made in sodium citrate buffer of $0.05 \mathrm{M}, \mathrm{pH} 4.8$

\begin{tabular}{|c|c|c|c|}
\hline Dilution No. & Citrate buffer $(\mathbf{m L})$ & $\mathbf{1 : 2 0}$ Enzyme $(\mathbf{m L})$ & Concentration \\
\hline 1 & 17 & 3 & 0.0075 \\
\hline 2 & 18 & 2 & 0.005 \\
\hline 3 & 18.5 & 1.5 & 0.00375 \\
\hline
\end{tabular}


Table A.29. Glucose concentration of samples as determined from standard curve $\left(35^{\circ} \mathrm{C}\right)$

\begin{tabular}{|c|c|c|c|c|c|c|c|c|}
\hline \multirow[b]{2}{*}{$\begin{array}{l}\text { Dilution } \\
\text { No. }\end{array}$} & \multicolumn{2}{|c|}{$\mathrm{CaCt}$} & \multicolumn{2}{|c|}{$C b C t$} & \multicolumn{2}{|c|}{ CaCt (without enzyme) } & \multicolumn{2}{|c|}{$C b C t$ (without enzyme) } \\
\hline & $\begin{array}{l}\text { A bs or bance } \\
540 \mathrm{~nm}\end{array}$ & $\begin{array}{l}\text { Glucose } \\
(\mathrm{mg} / 0.5 \mathrm{~mL})\end{array}$ & $\begin{array}{l}\text { Absorbance } \\
540 \mathrm{~nm}\end{array}$ & $\begin{array}{l}\text { Glucose } \\
(\mathrm{mg} / 0.5 \mathrm{~mL})\end{array}$ & $\begin{array}{l}\text { Abs or bance } \\
540 \mathrm{~nm}\end{array}$ & $\begin{array}{l}\text { Glucose } \\
(\mathrm{mg} / 0.5 \mathrm{~mL})\end{array}$ & $\begin{array}{l}\text { Abs or bance } \\
540 \mathrm{~nm}\end{array}$ & Glucose $(\mathrm{mg} / 0.5 \mathrm{~mL})$ \\
\hline 1 & 0.48 & 1.98 & 0.505 & 2.06 & 0.515 & 2.12 & 0.518 & 2.14 \\
\hline 2 & 0.32 & 1.28 & 0.31 & 1.25 & 0.3205 & 1.32 & 0.335 & 1.35 \\
\hline 3 & 0.225 & 0.98 & 0.23 & 0.92 & 0.24 & 0.98 & 0.262 & 1.05 \\
\hline
\end{tabular}

Table A.30. Glucose concentration of samples as determined from standard curve $\left(45^{\circ} \mathrm{C}\right)$

\begin{tabular}{|c|c|c|c|c|c|c|c|c|}
\hline \multirow[b]{2}{*}{$\begin{array}{l}\text { Dilution } \\
\text { No. }\end{array}$} & \multicolumn{2}{|c|}{$\mathrm{CaCt}$} & \multicolumn{2}{|c|}{$\mathrm{CbCt}$} & \multicolumn{2}{|c|}{ CaCt (without enzyme) } & \multicolumn{2}{|c|}{$C b C t$ (without enzyme) } \\
\hline & $\begin{array}{l}\text { Absorbance } \\
540 \mathrm{~nm}\end{array}$ & $\begin{array}{l}\text { Glucose } \\
(\mathrm{mg} / 0.5 \mathrm{~mL})\end{array}$ & $\begin{array}{l}\text { Absor bance } \\
540 \mathrm{~nm}\end{array}$ & $\begin{array}{l}\text { Glucose } \\
(\mathrm{mg} / 0.5 \mathrm{~mL})\end{array}$ & $\begin{array}{l}\text { A bs or bance } \\
540 \mathrm{~nm}\end{array}$ & $\begin{array}{l}\text { Glucose } \\
(\mathrm{mg} / 0.5 \mathrm{~mL})\end{array}$ & $\begin{array}{l}\text { Absor bance } \\
540 \mathrm{~nm}\end{array}$ & Glucose $(\mathrm{mg} / 0.5 \mathrm{~mL})$ \\
\hline 1 & 0.525 & 2.18 & 0.58 & 2.4 & 0.59 & 2.45 & 0.6 & 2.48 \\
\hline 2 & 0.34 & 1.38 & 0.34 & 1.35 & 0.3405 & 1.41 & 0.44 & 1.8 \\
\hline 3 & 0.26 & 1.02 & 0.26 & 1.02 & 0.28 & 1.12 & 0.29 & 1.17 \\
\hline
\end{tabular}




\section{Appendix B. Sugars, ABE, and Acids Standards (HPLC)}

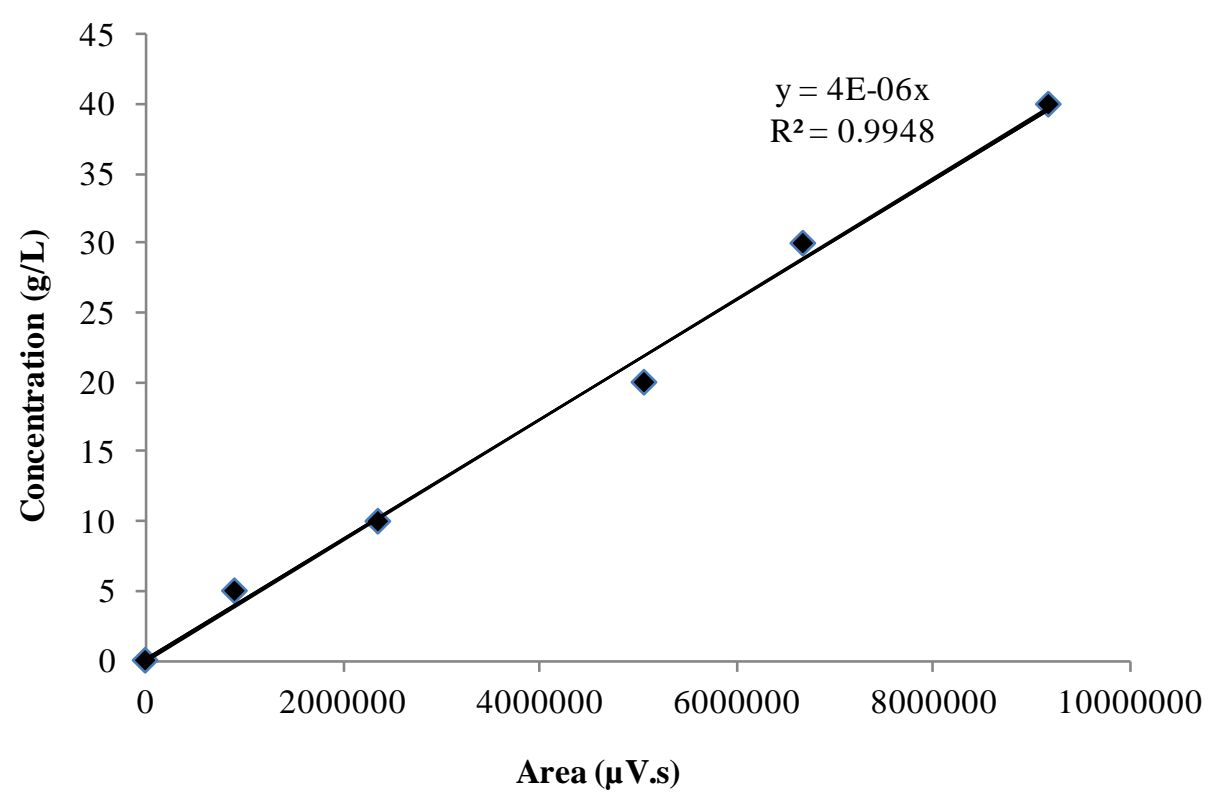

Figure B.1. HPLC standard curve for Glucose

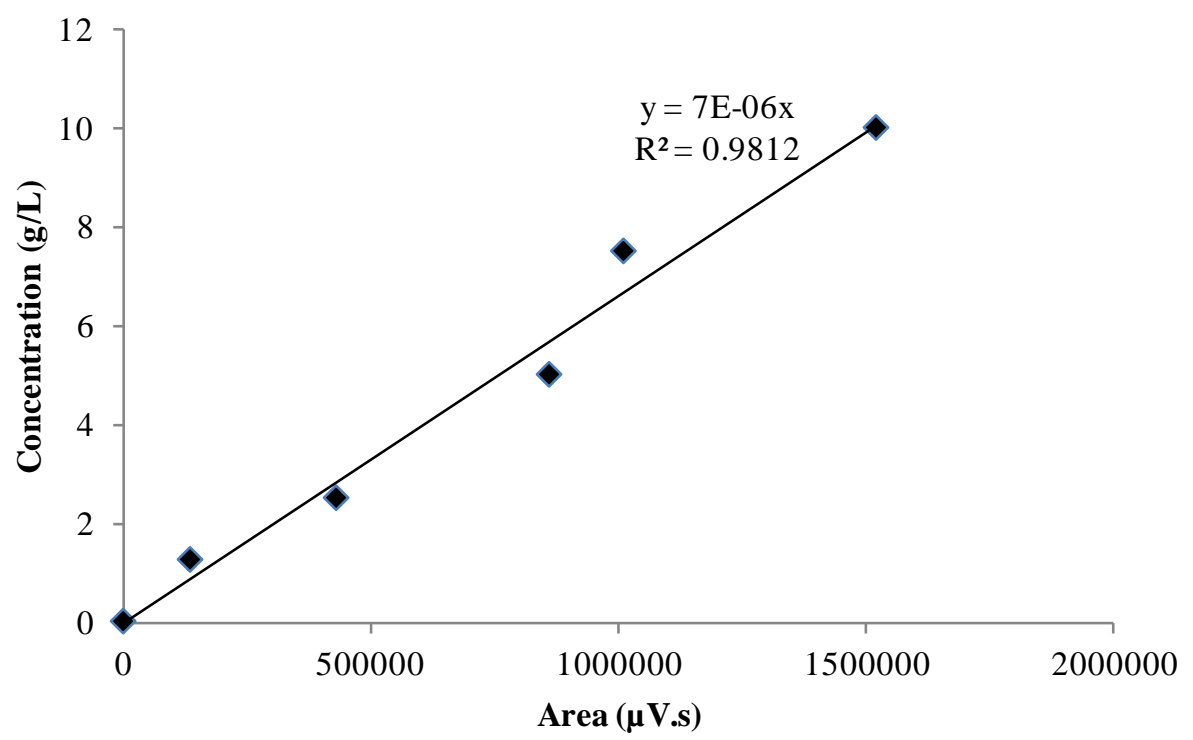

Figure B.2. HPLC standard curve for Galactose 


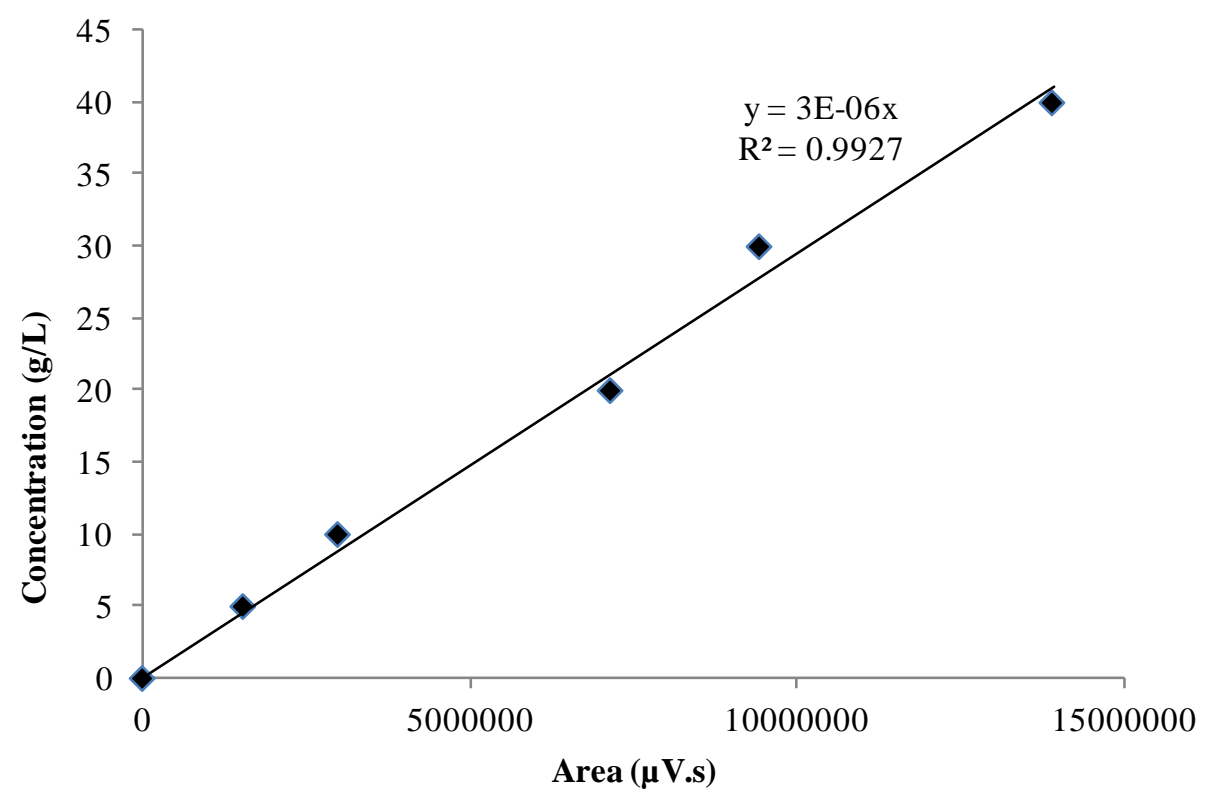

Figure B.3. HPLC standard cur ve for Xylose

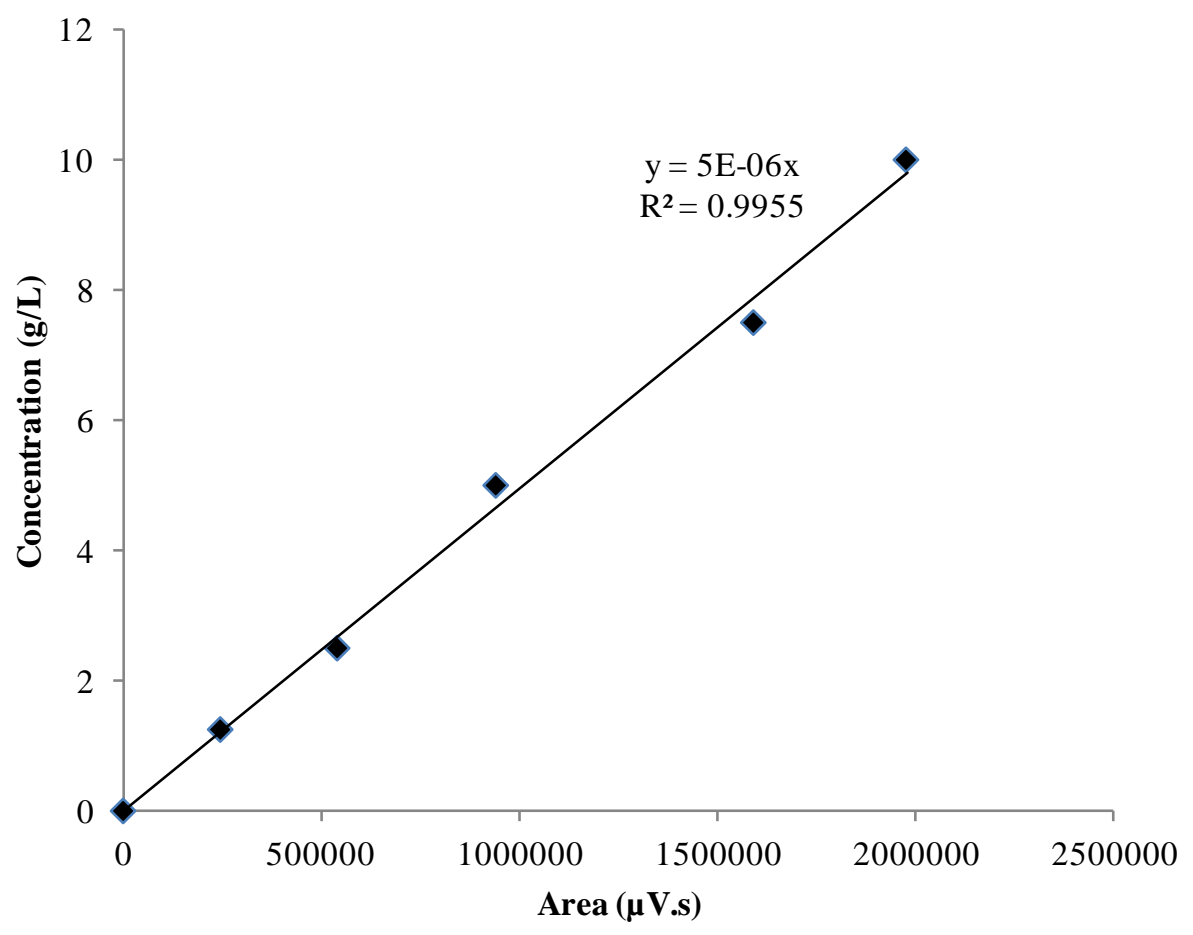

Figure B.4. HPLC standard cur ve for Mannose 


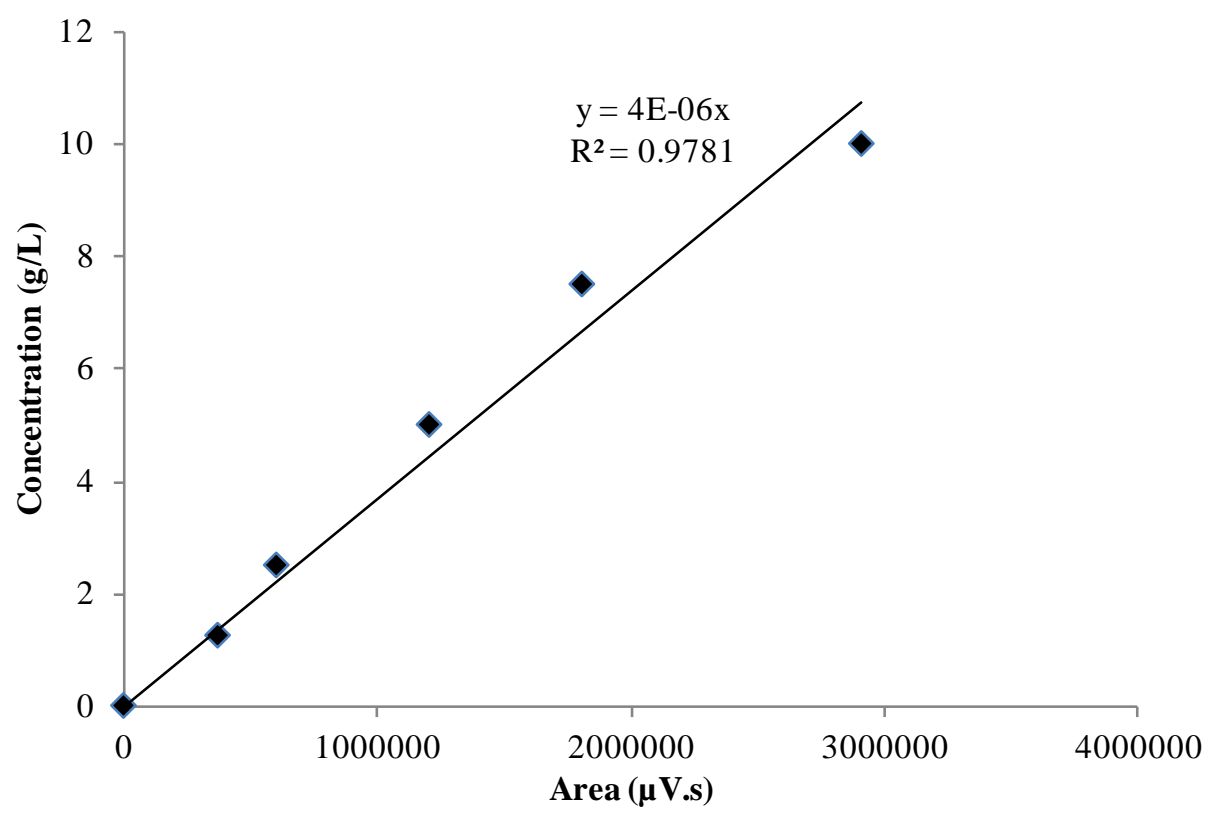

Figure B.5. HPLC standard curve for Arabinose

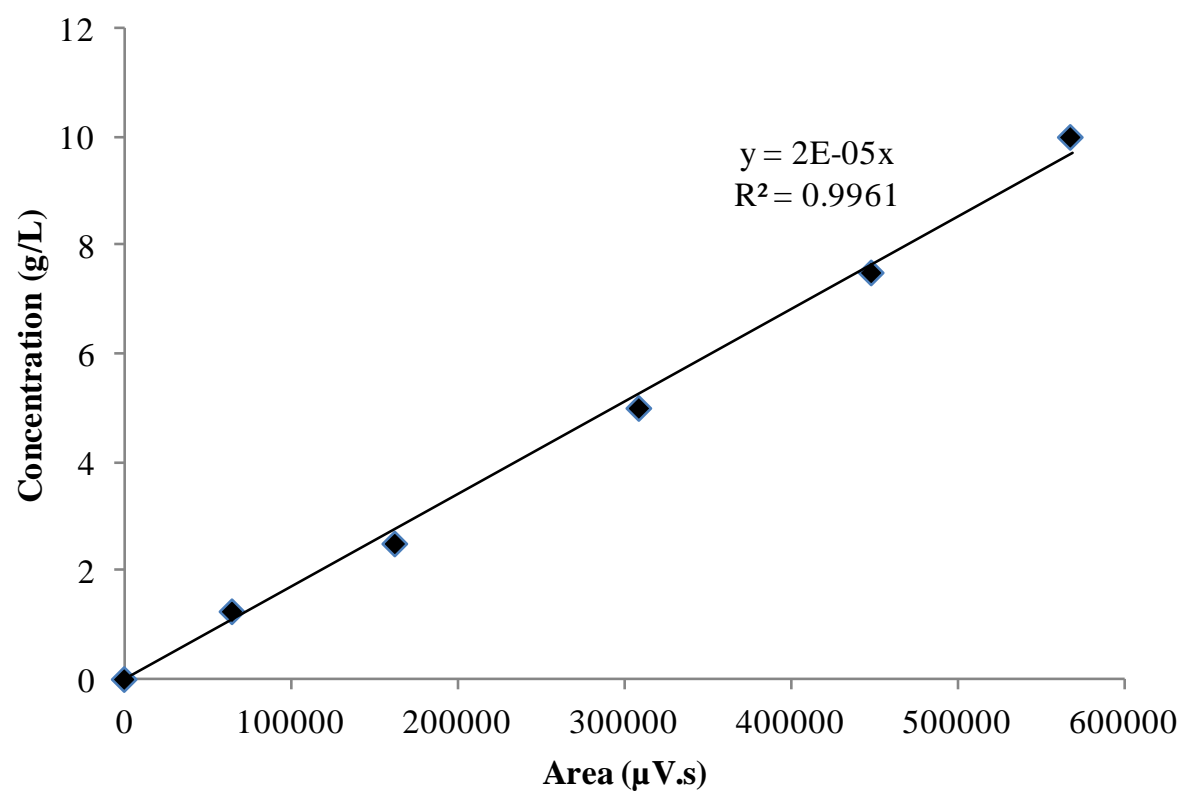

Figure B.6. HPLC standard curve for Acetone 


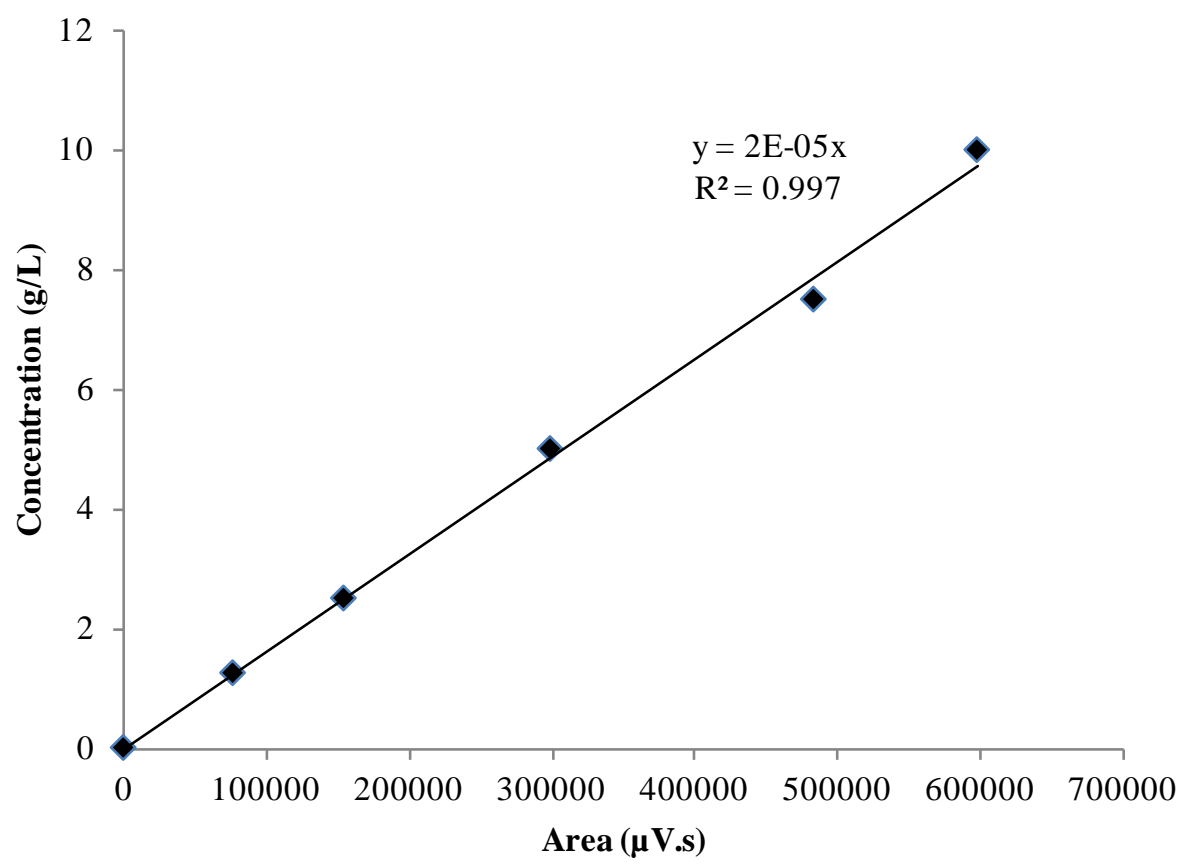

Figure B.7. HPLC standard curve for Butanol

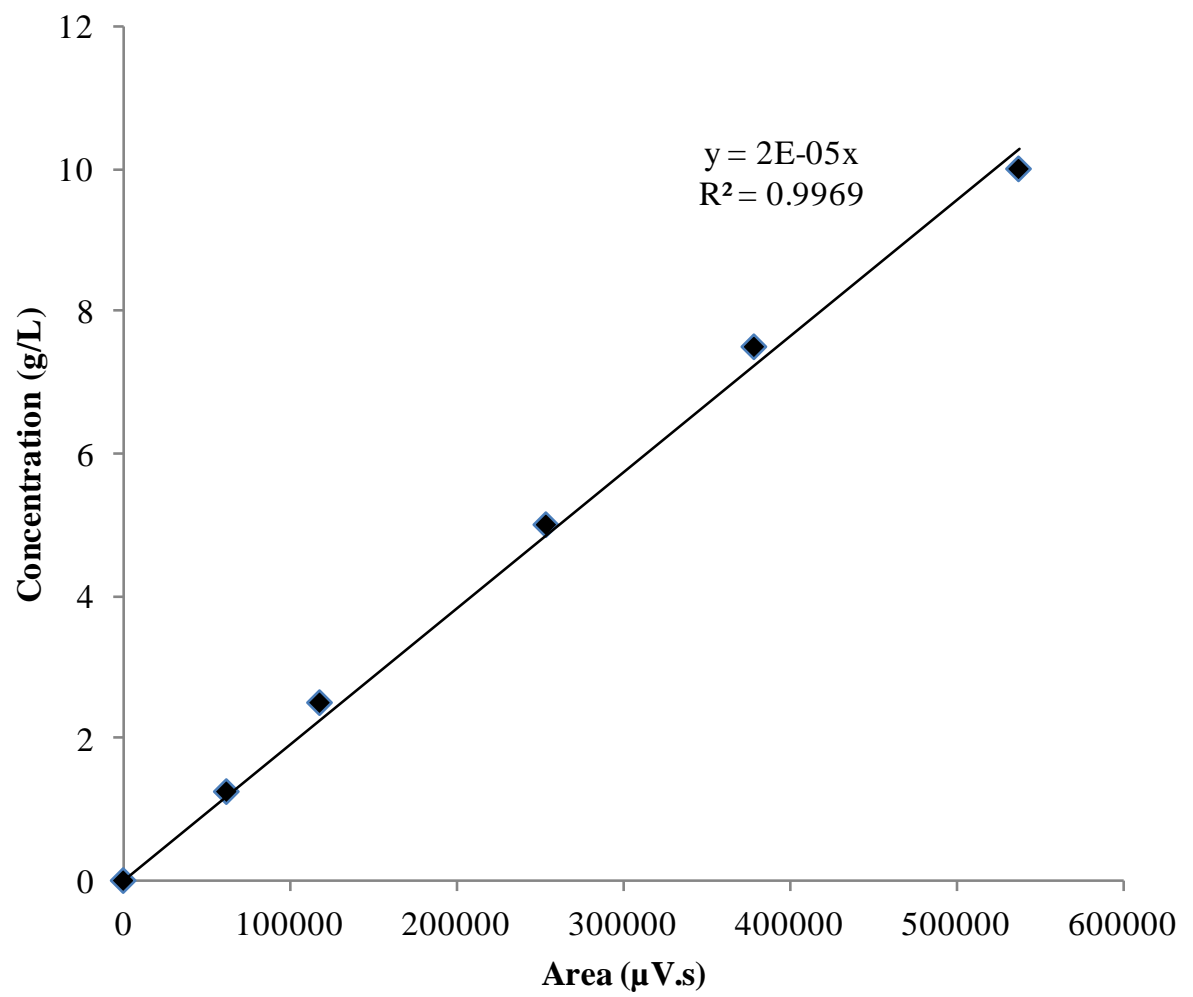

Figure B.8. HPLC standard curve for Ethanol 


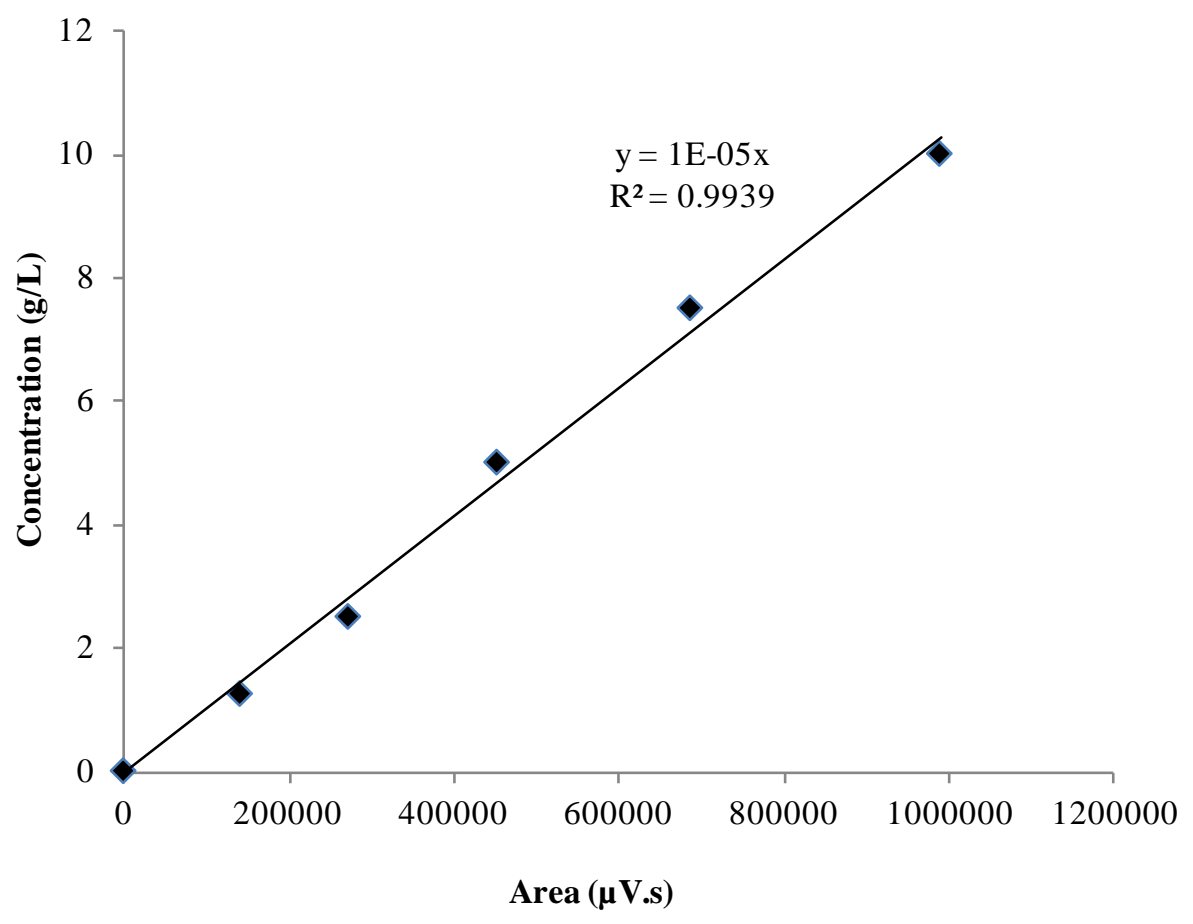

Figure B.9. HPLC standard curve for Acetic acid

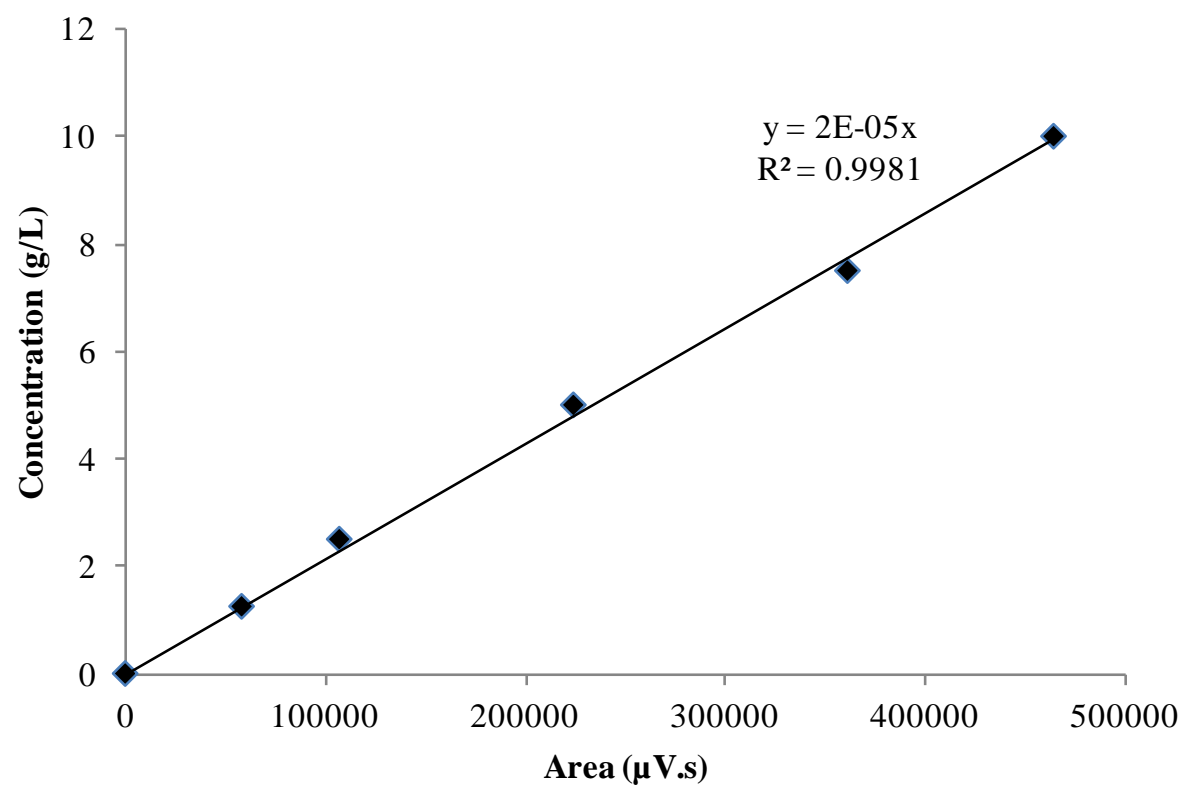

Figure B.10. HPLC standard curve for Butyric acid 


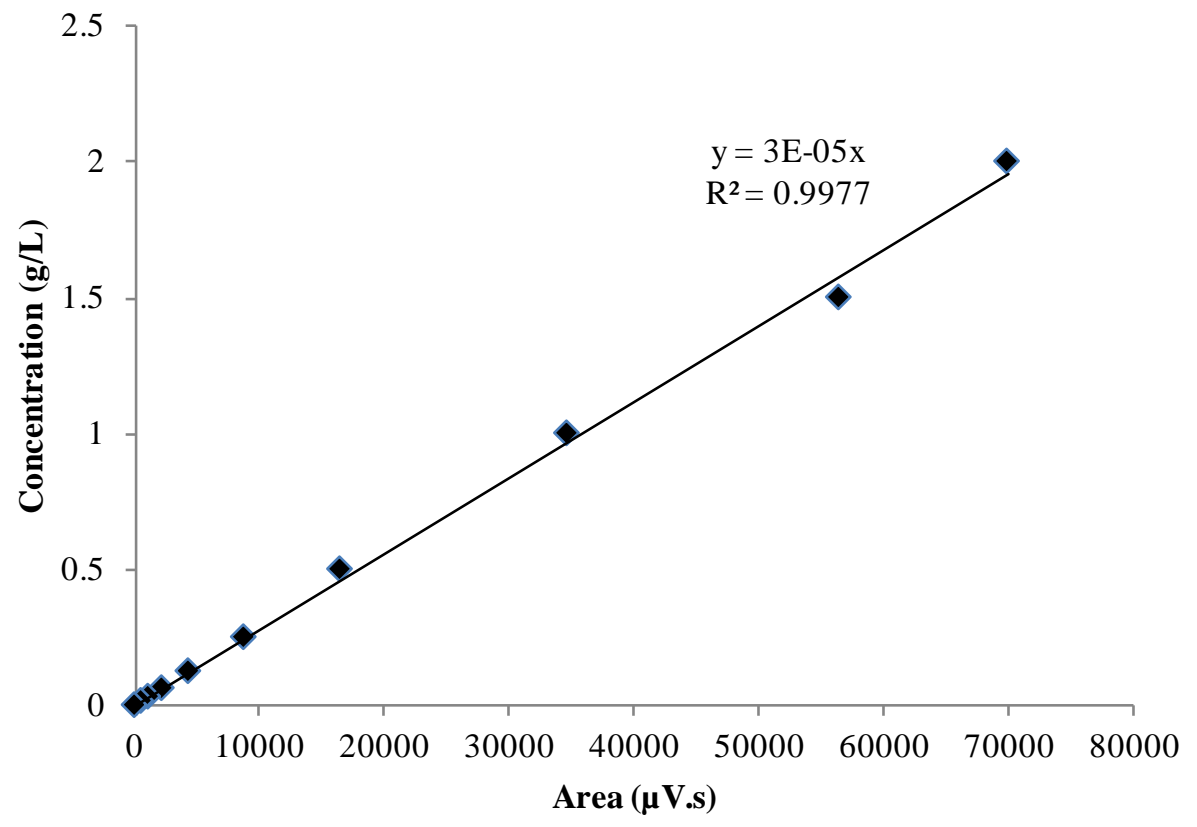

Figure B.11. HPLC standard curve for Furfural 


\section{Appendix C. Specific growth rate}

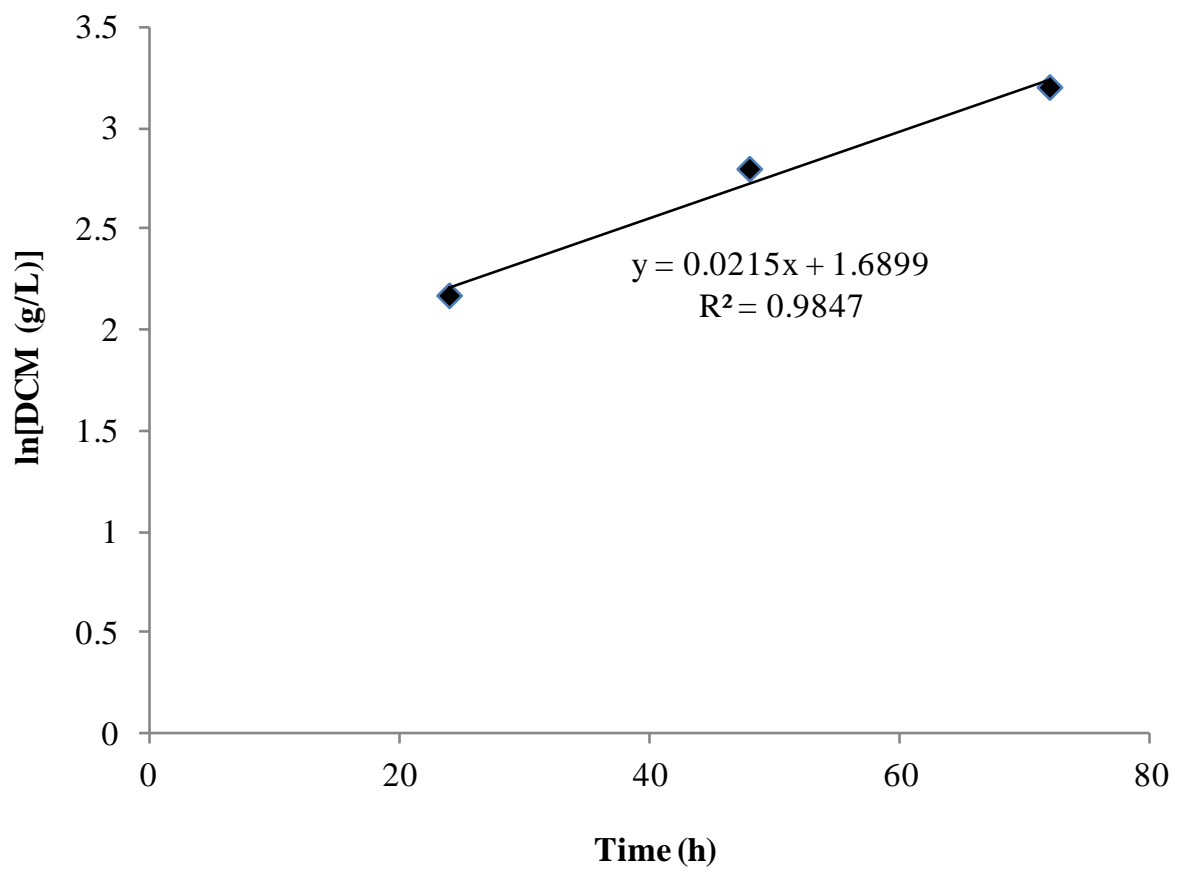

Figure C.1. Growth curve of $\mathrm{Ca}$ at $35^{\circ} \mathrm{C}$ for s pecific growth rate calculation

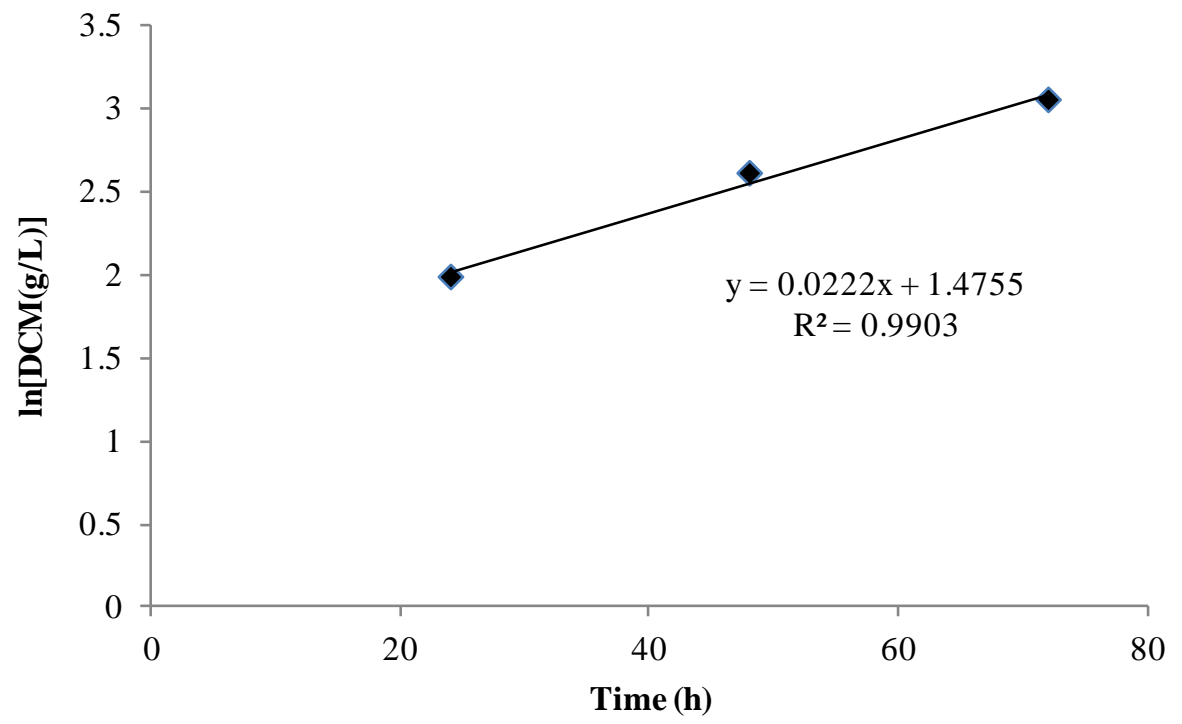

Figure C.2. Growth curve of $\mathrm{Cb}$ at $35^{\circ} \mathrm{C}$ for s pecific growth rate calculation 


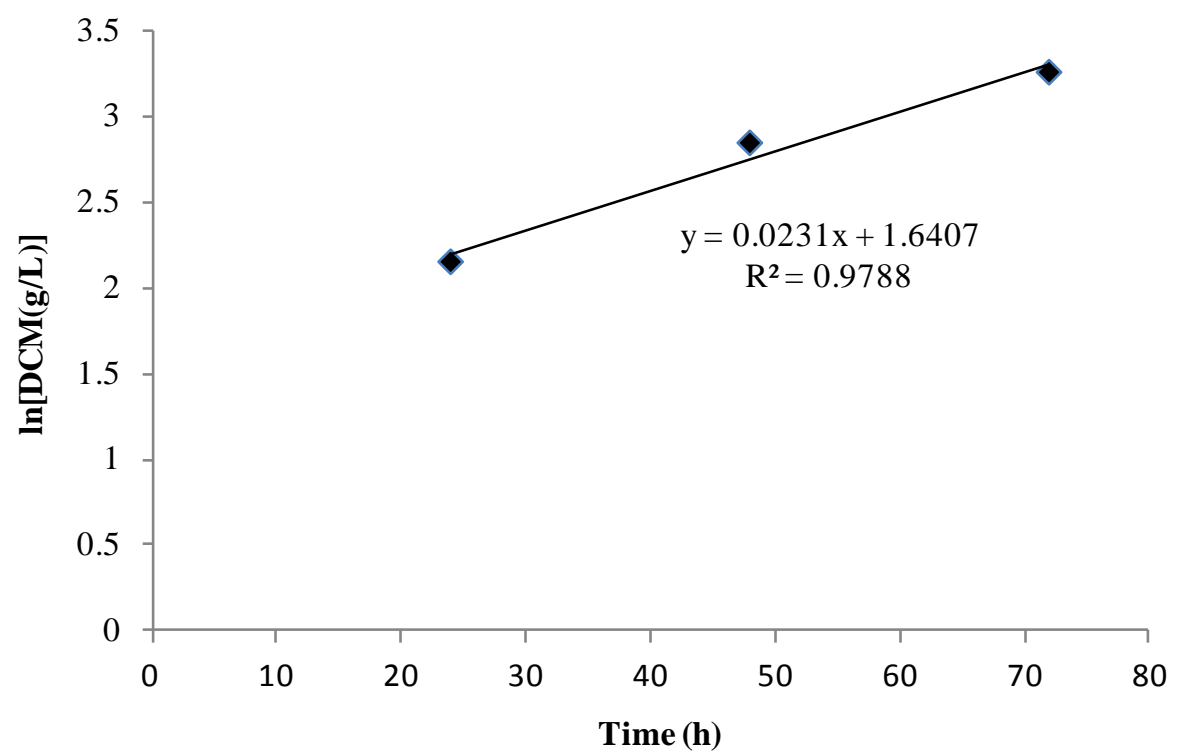

Figure C.3. Growth curve of $\mathrm{CaCb}$ at $35^{\circ} \mathrm{C}$ for specific growth rate calculation

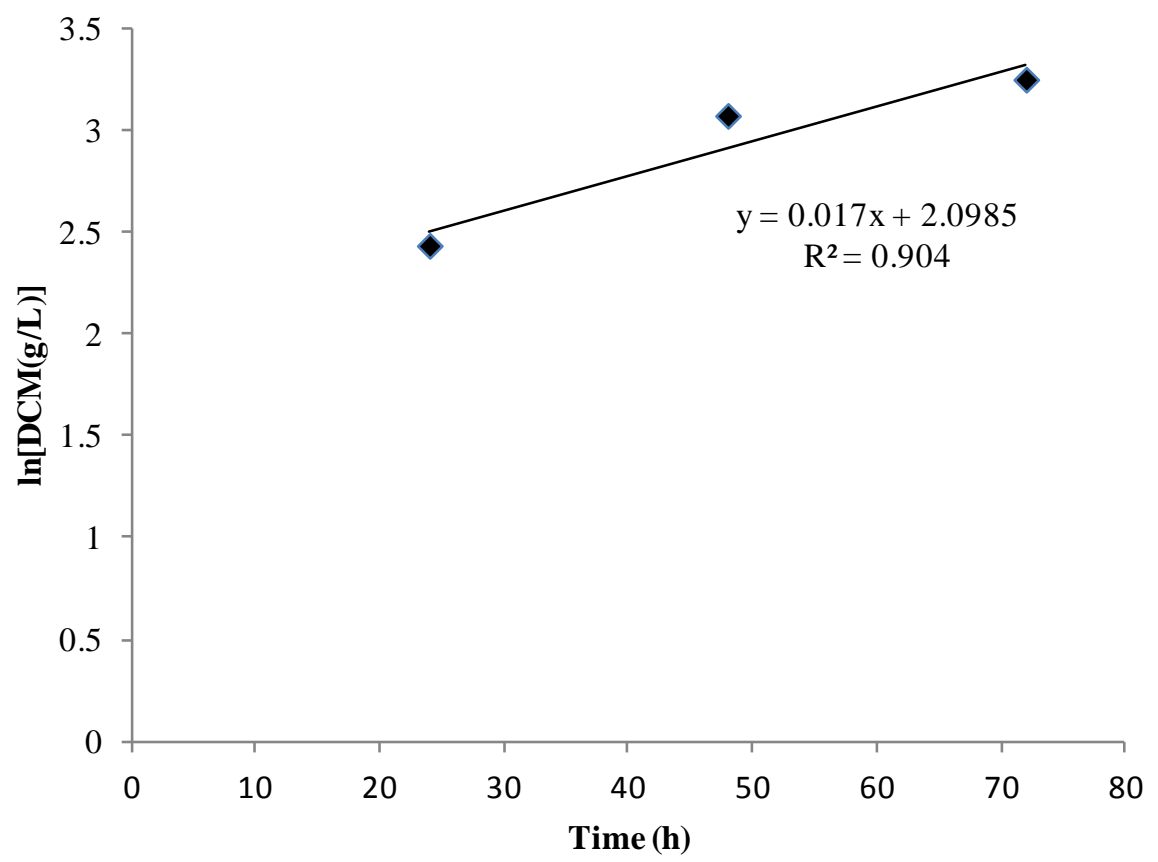

Figure C.4. Growth curve of $\mathrm{CaCt}$ at $35^{\circ} \mathrm{C}$ for specific growth rate calculation 


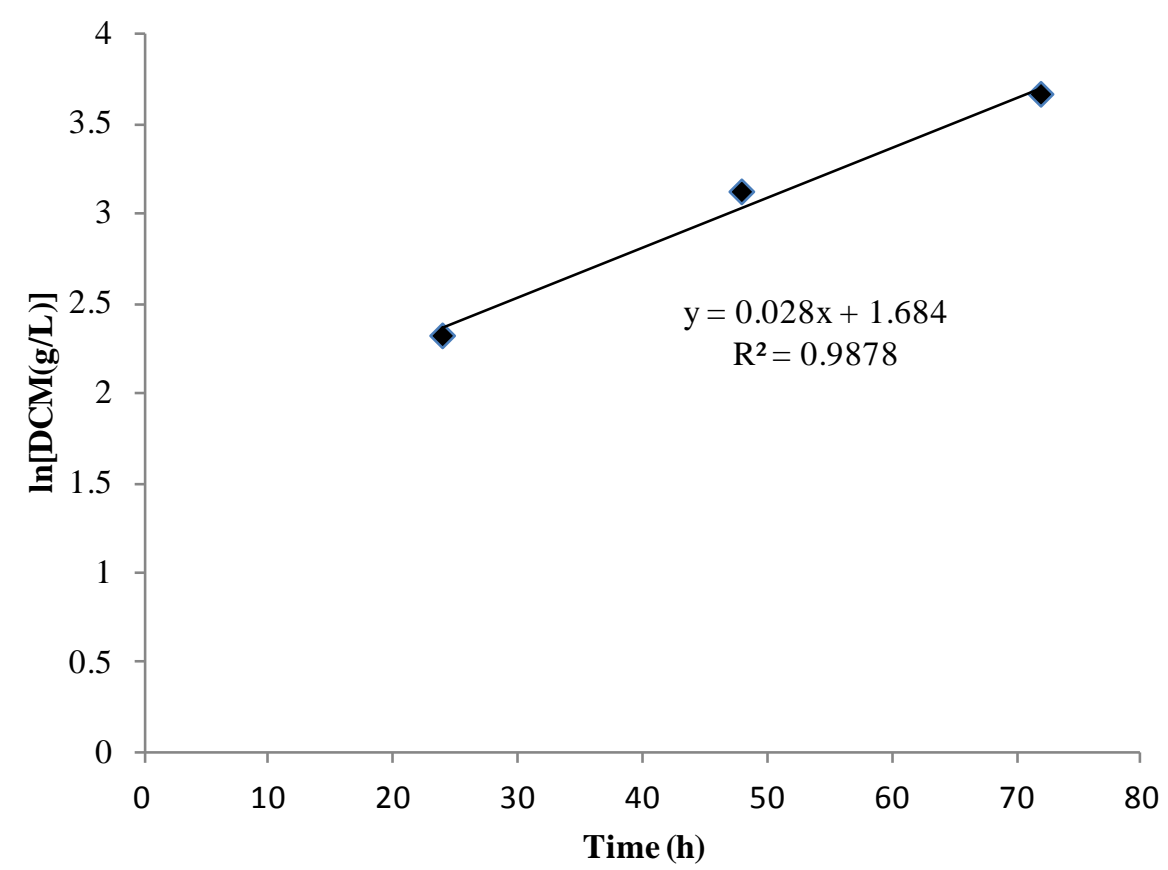

Figure C.5. Growth curve of $\mathrm{CbCt}$ at $35^{\circ} \mathrm{C}$ for specific growth rate calculation

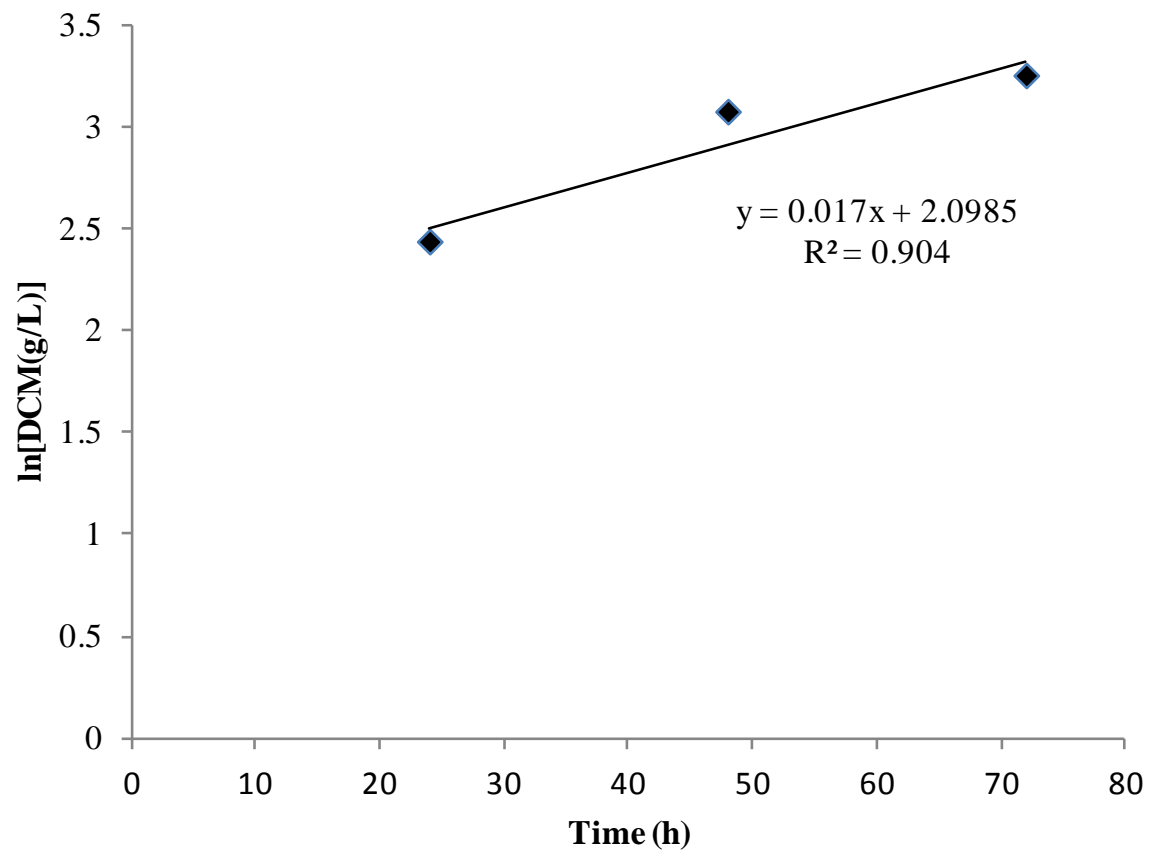

Figure C.6. Growth curve of $\mathrm{CaCt}$ (without enzyme) at $35^{\circ} \mathrm{C}$ for s pecific growth rate calculation 


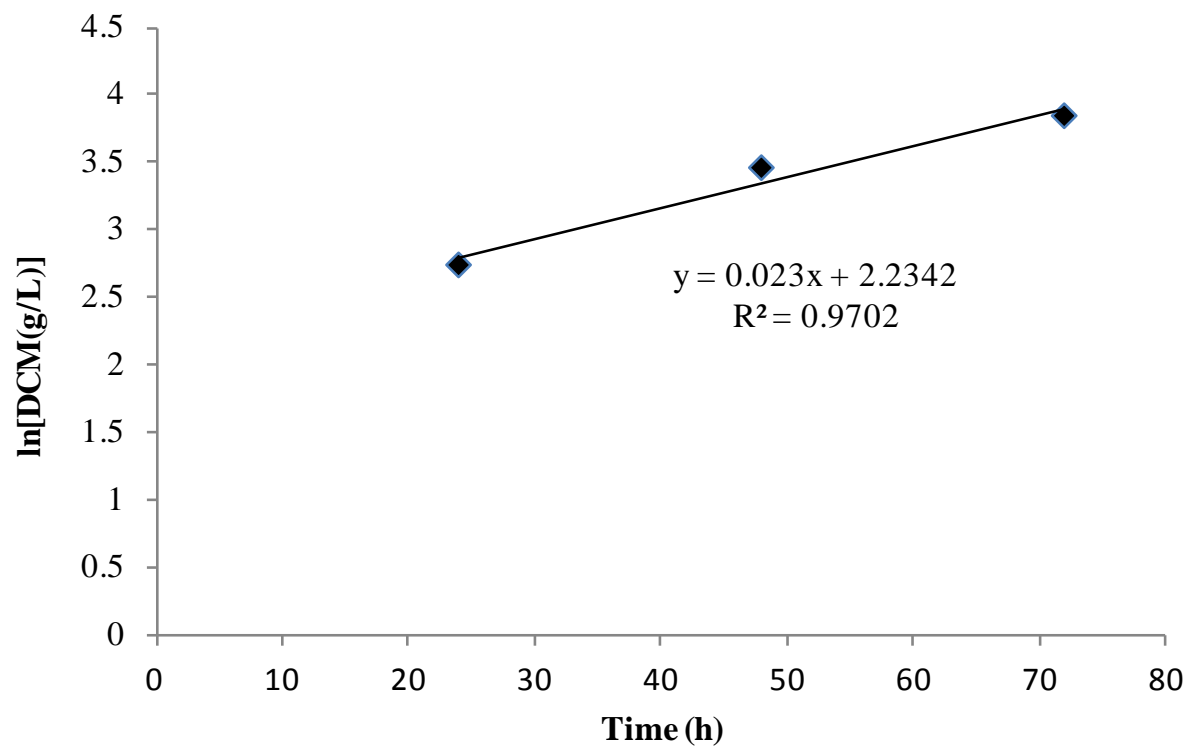

Figure C.7. Growth curve of $\mathrm{CbCt}$ (without enzyme) at $35^{\circ} \mathrm{C}$ for s pecific growth rate calculation

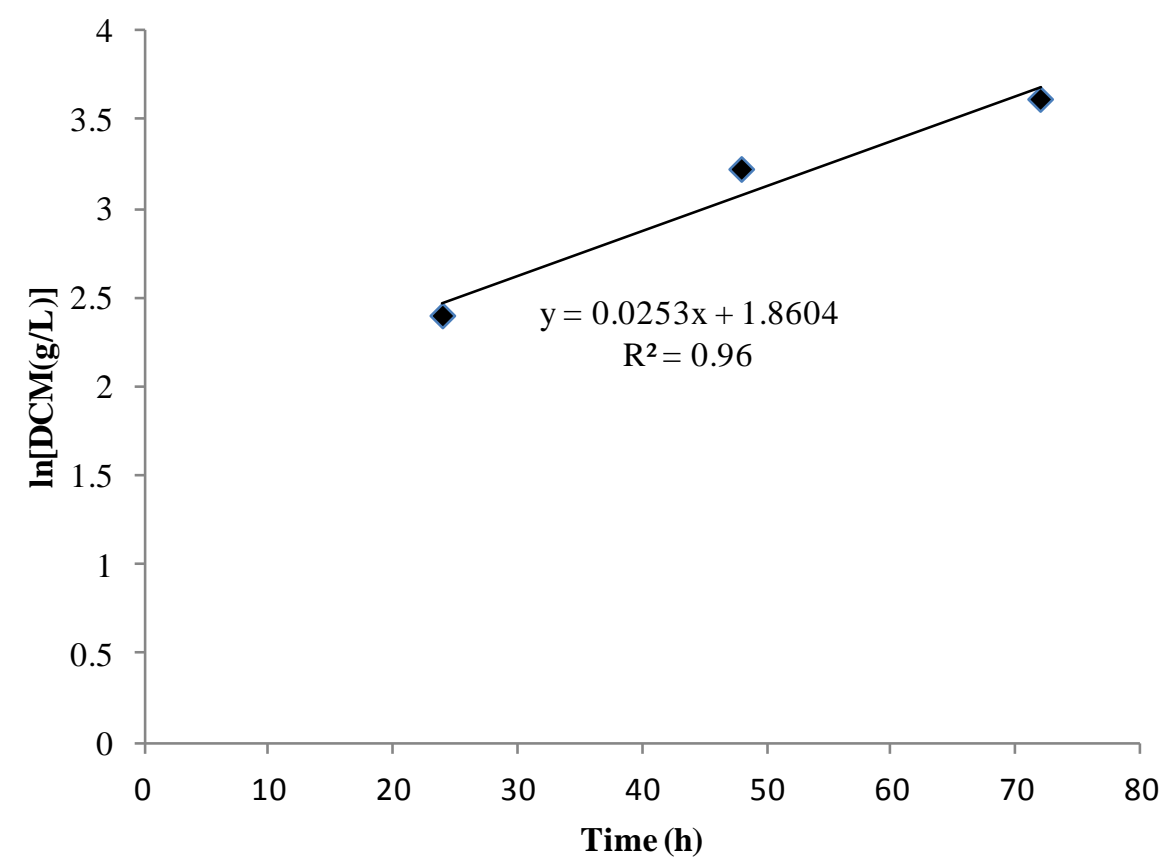

Figure C.8. Growth curve of $\mathrm{CaCt}$ at $45^{\circ} \mathrm{C}$ for specific growth rate calculation 


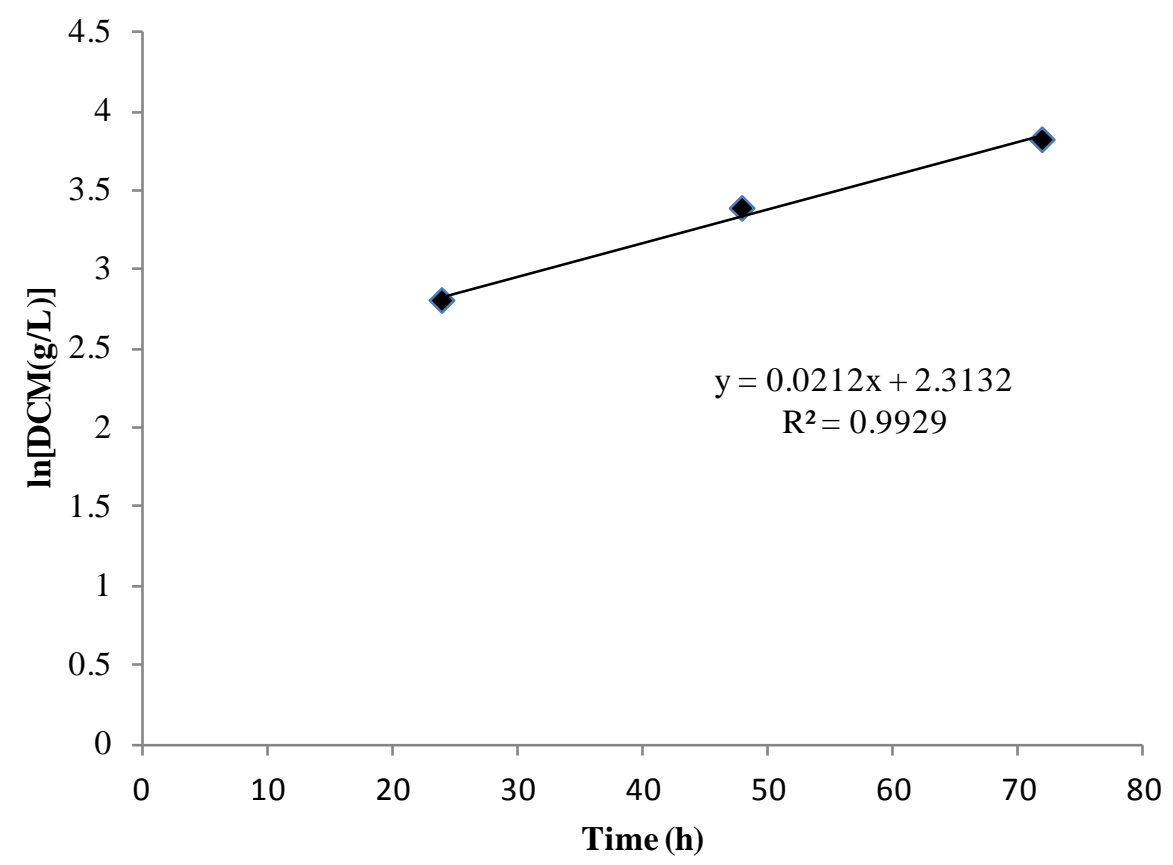

Figure C.9. Growth curve of $\mathrm{CbCt}$ at $45^{\circ} \mathrm{C}$ for specific growth rate calculation

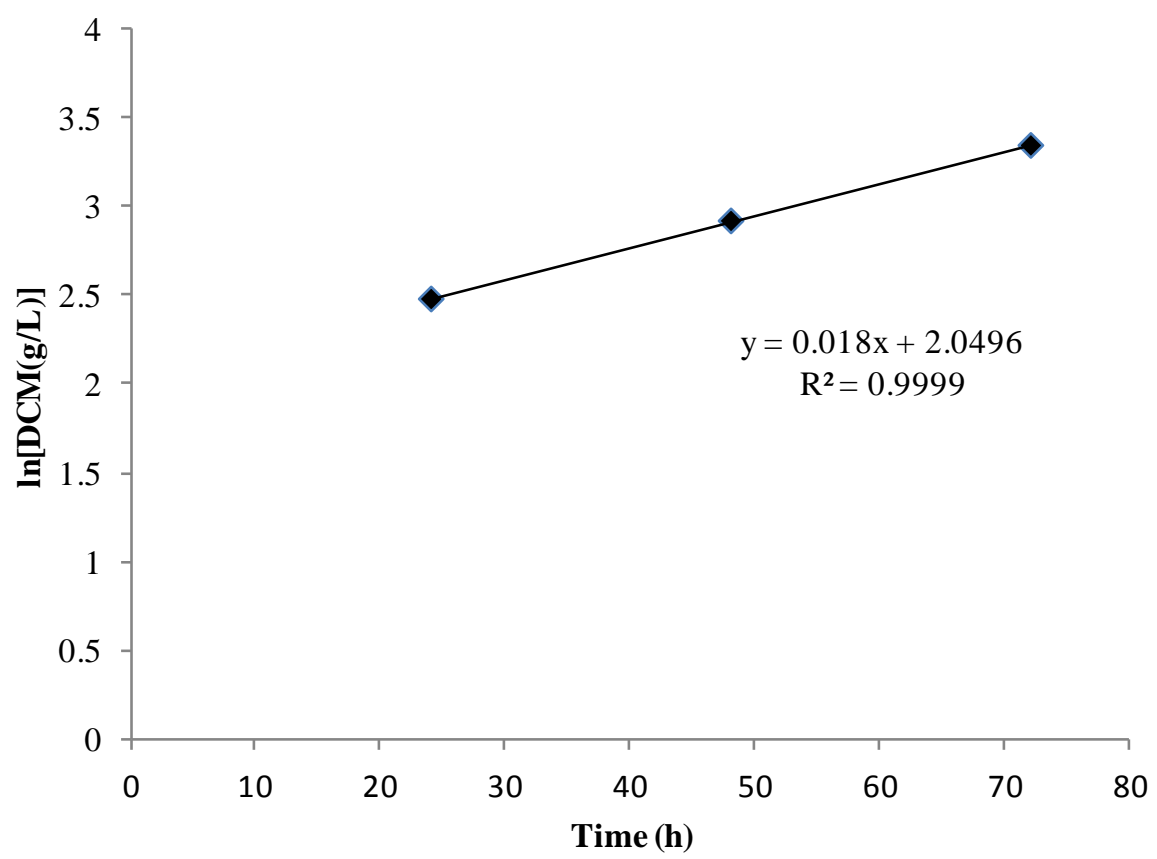

Figure C.10. Growth curve of $\mathrm{CaCt}$ (without enzyme) at $45^{\circ} \mathrm{C}$ for specific growth rate calculation 


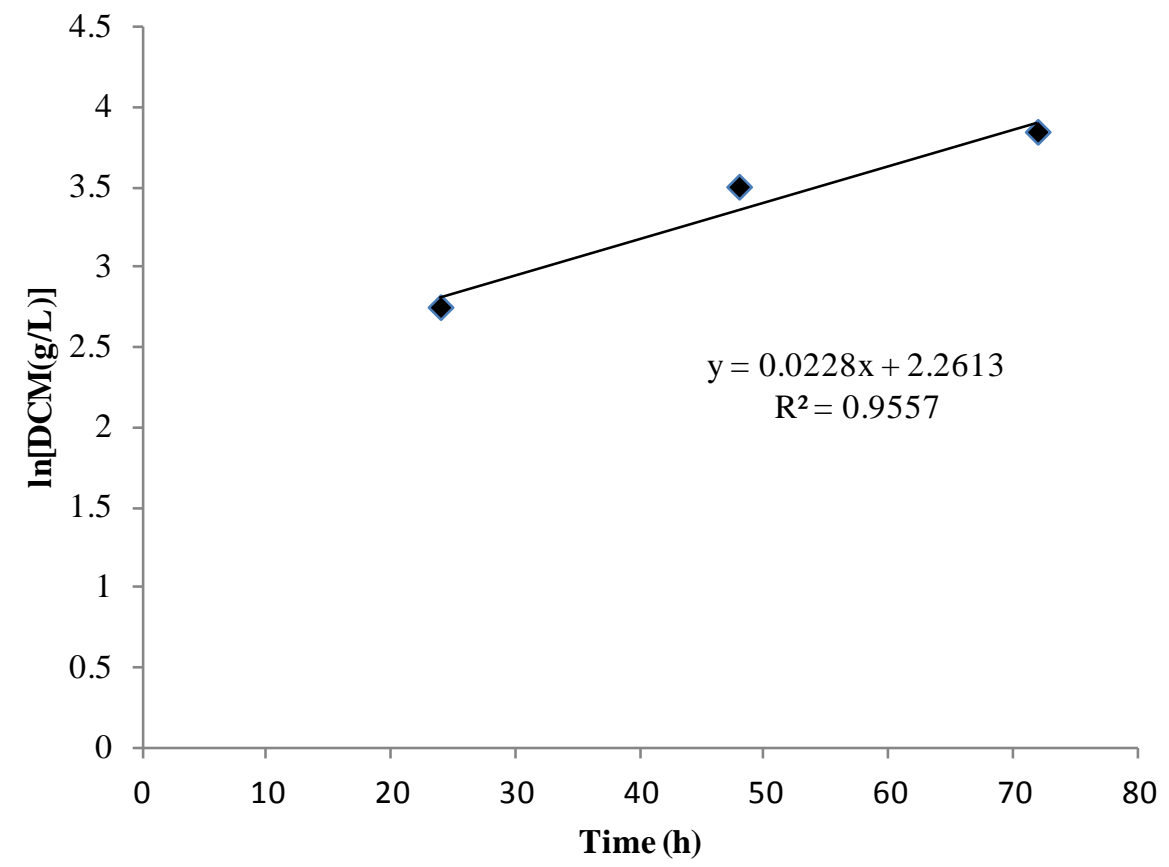

Figure C.11. Growth curve of $\mathrm{CbCt}$ (without enzyme) at $45^{\circ} \mathrm{C}$ for specific growth rate calculation 


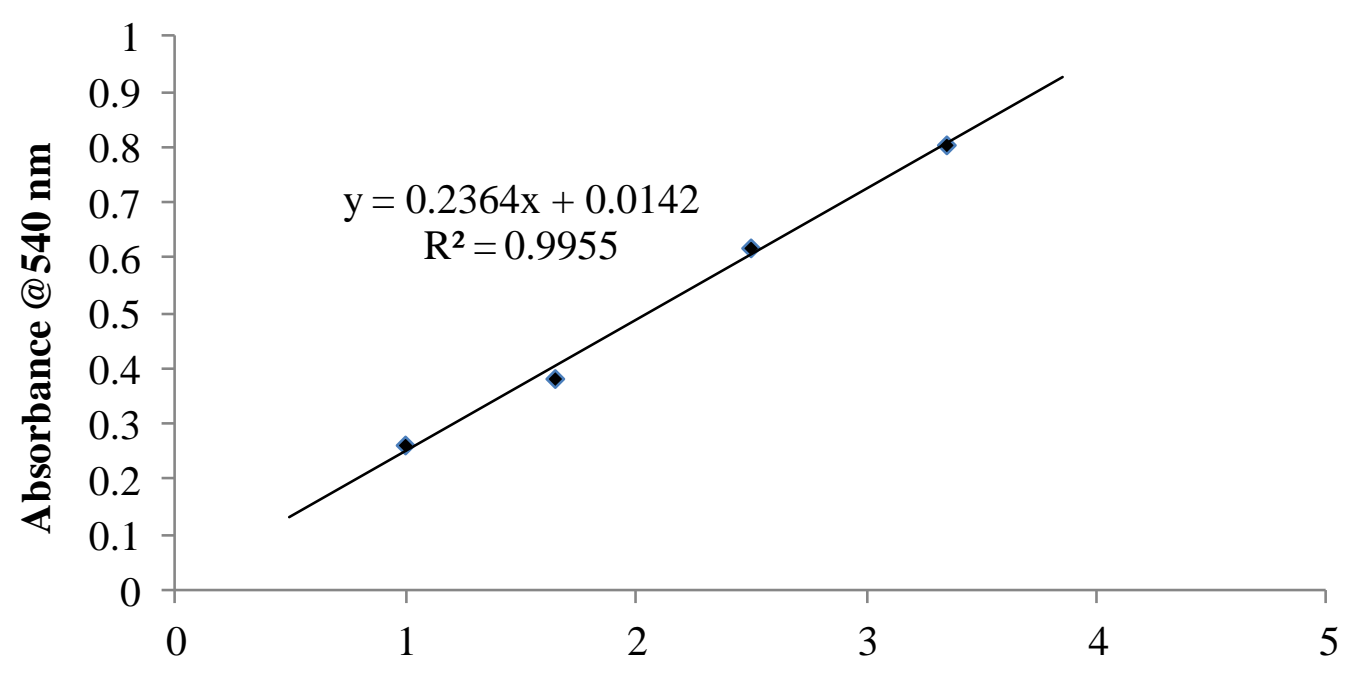

Glucose concentration $(\mathrm{mg} / 0.5 \mathrm{~mL})$

Figure D.1. Glucose standard curve for FPA assay

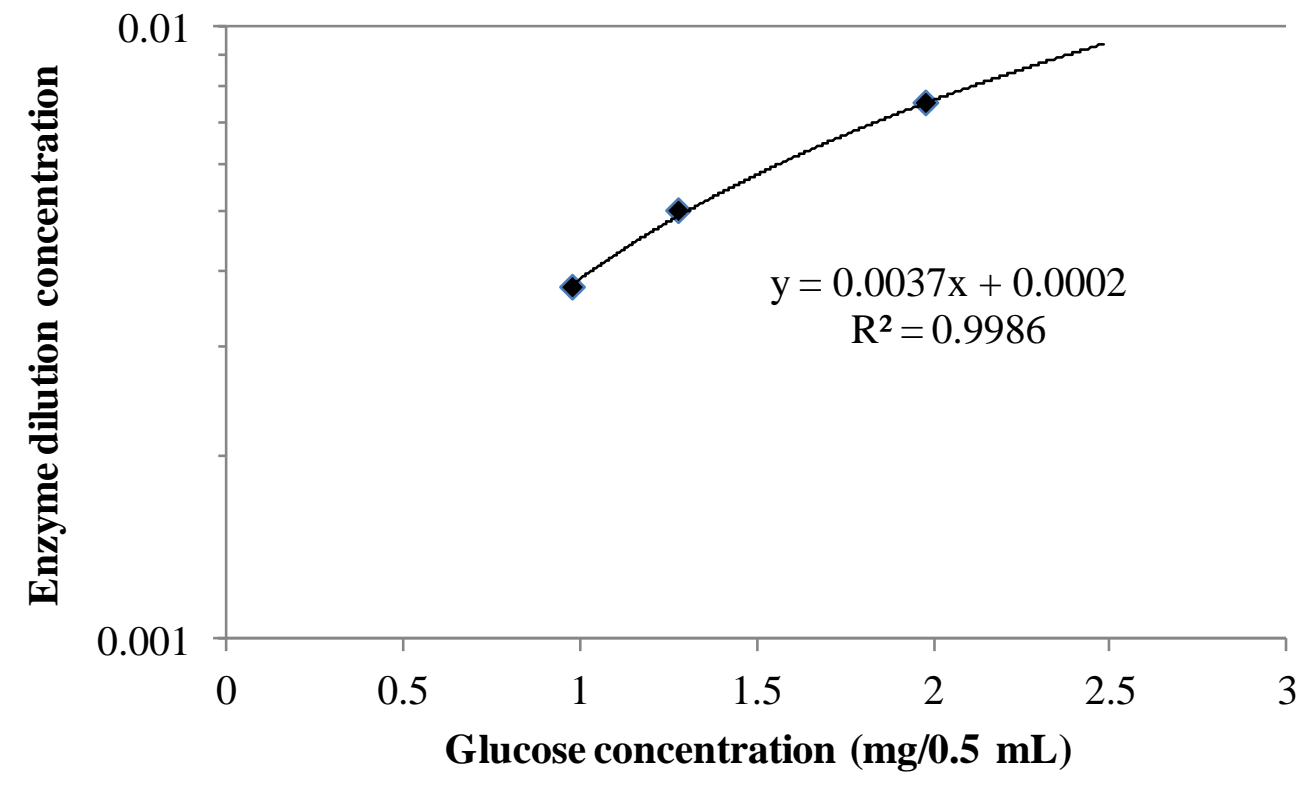

Figure D.2. Enzyme dilution concentration us. Glucose concentration for $\mathrm{CaCt} @ 35^{\circ} \mathrm{C}$ 


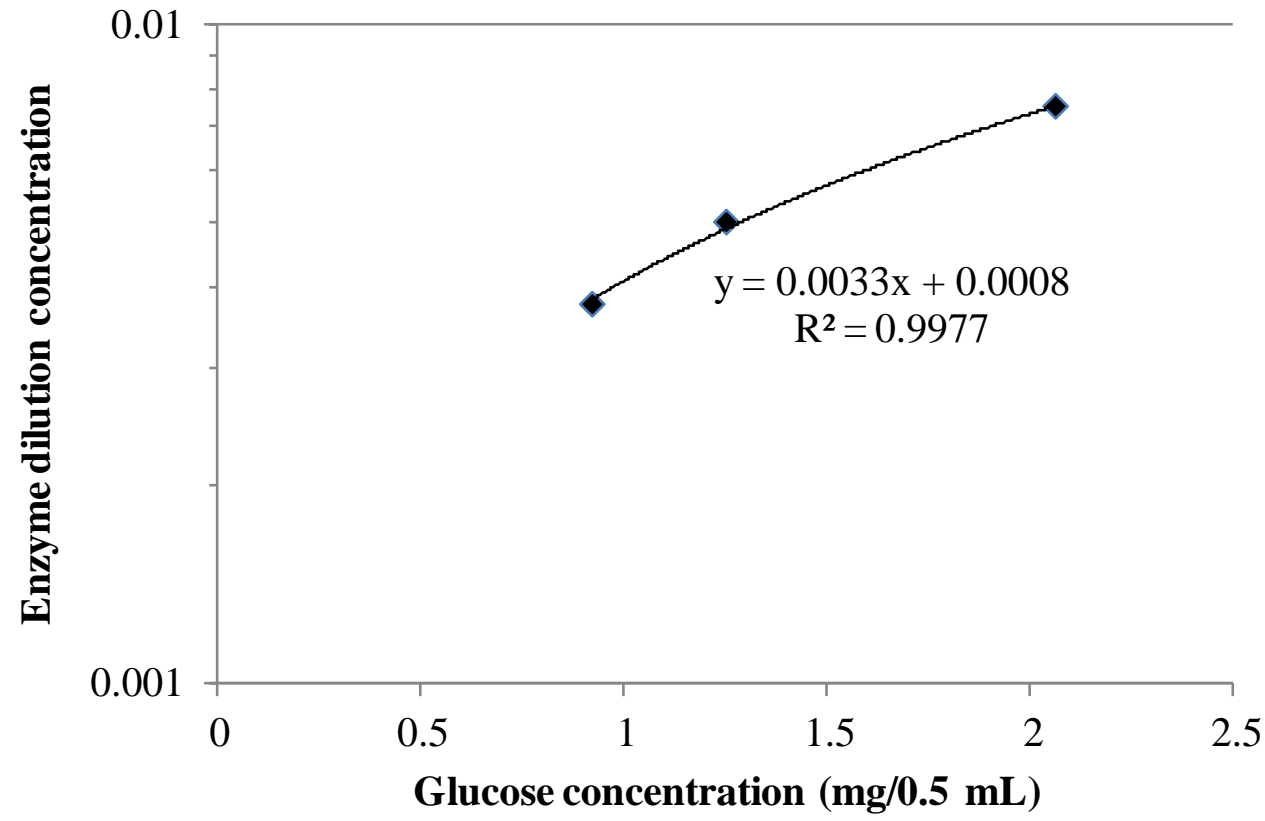

Figure D.3. Enzyme dilution concentration vs. Glucose concentration for $\mathrm{CbCt} @ 35^{\circ} \mathrm{C}$

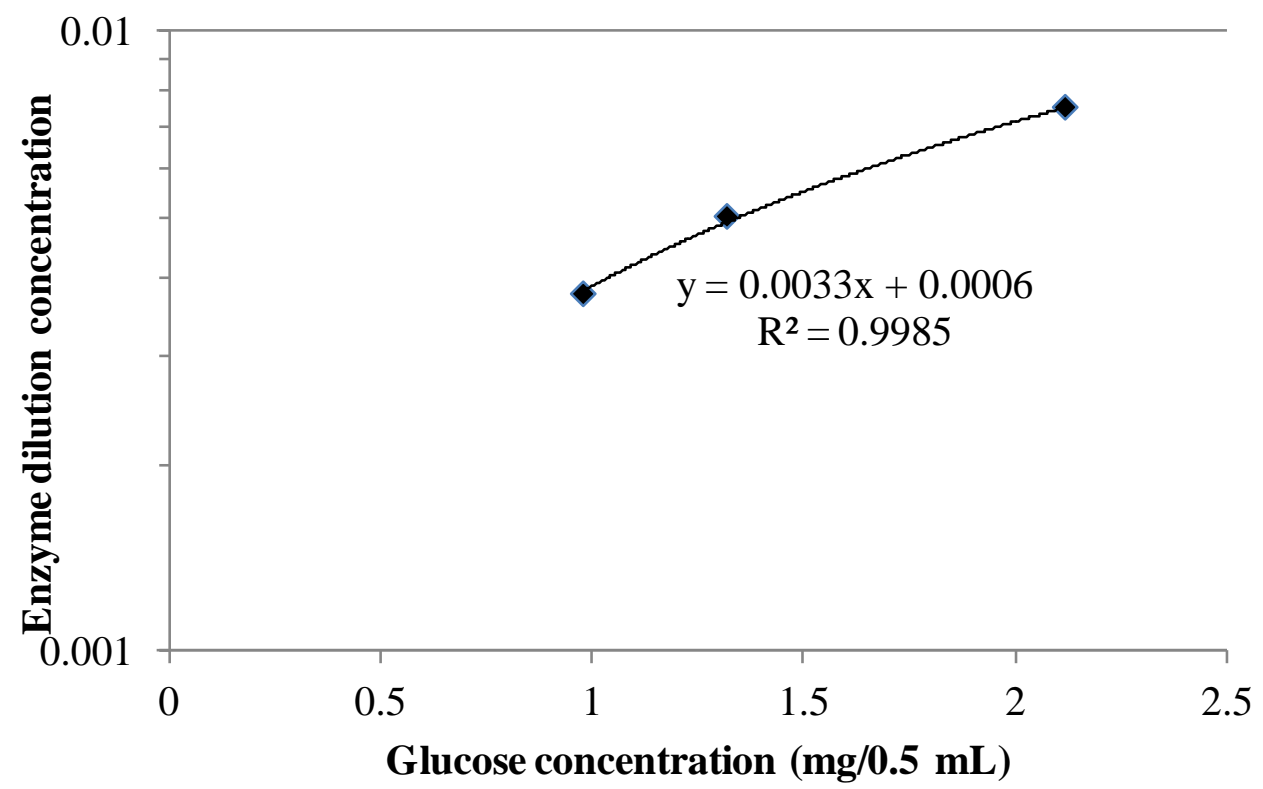

Figure D.4. Enzyme dilution concentration vs. Glucose concentration for $\mathrm{CaCt}$ (without enzyme) @ $35^{\circ} \mathrm{C}$ 


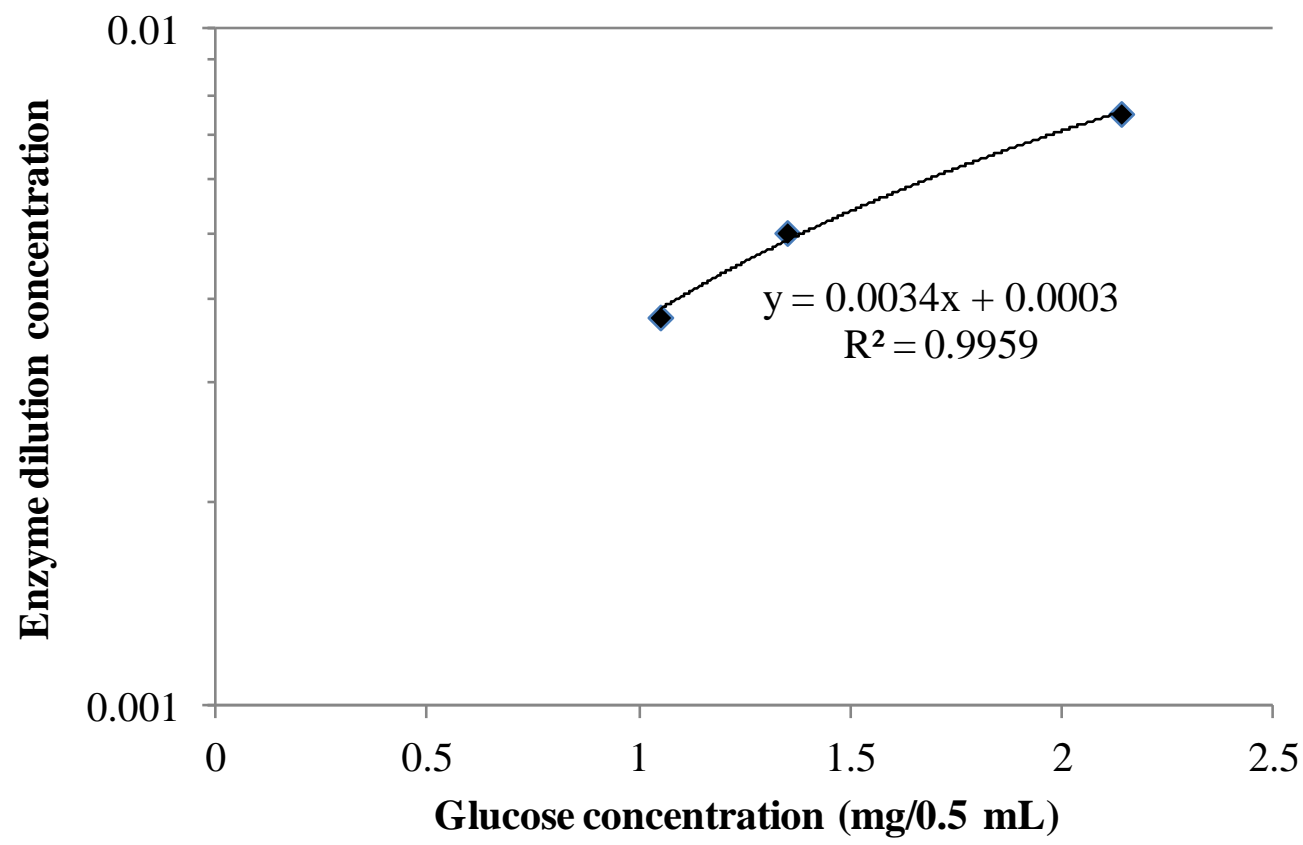

Figure D.5. Enzyme dilution concentration us. Glucose concentration for $C b C t$ (without enzyme) @ $35^{\circ} \mathrm{C}$

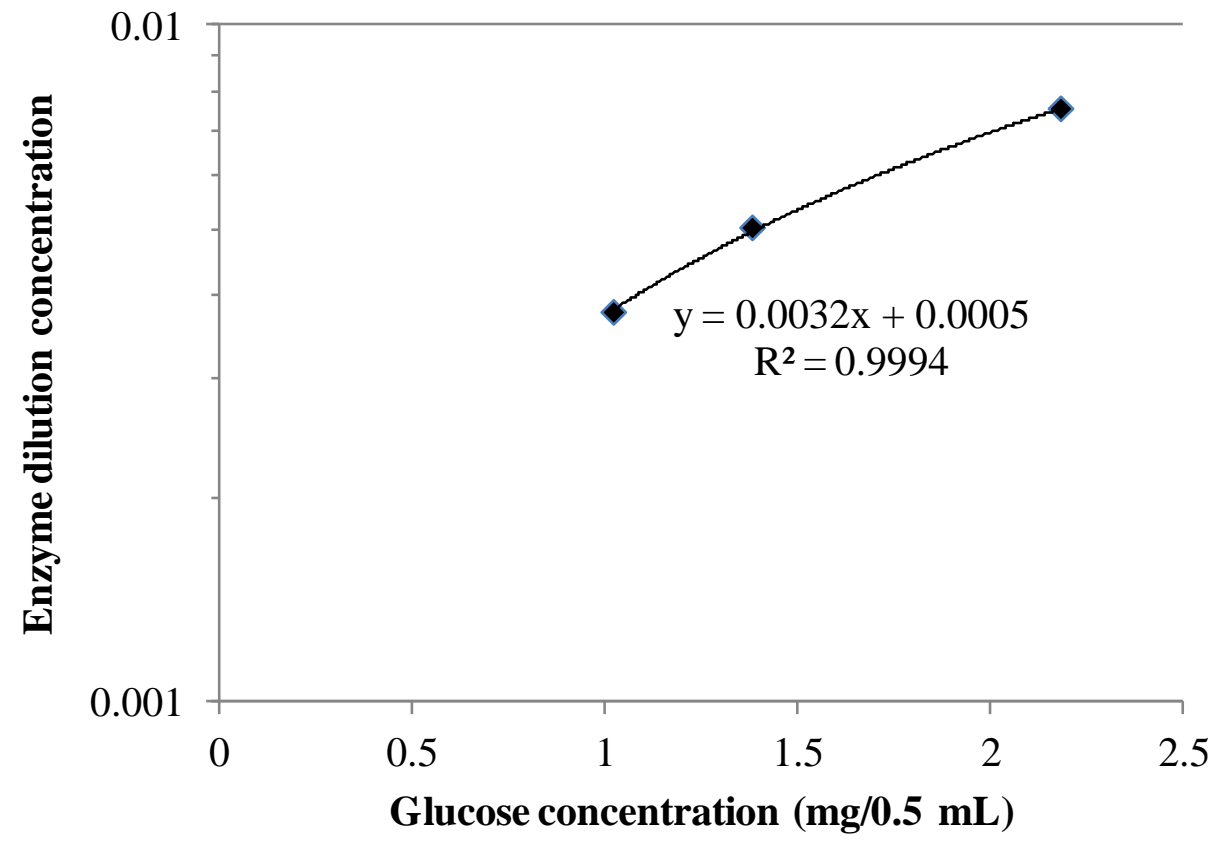

Figure D.6. Enzyme dilution concentration vs. Glucose concentration for $\mathrm{CaCt} @ 45^{\circ} \mathrm{C}$ 


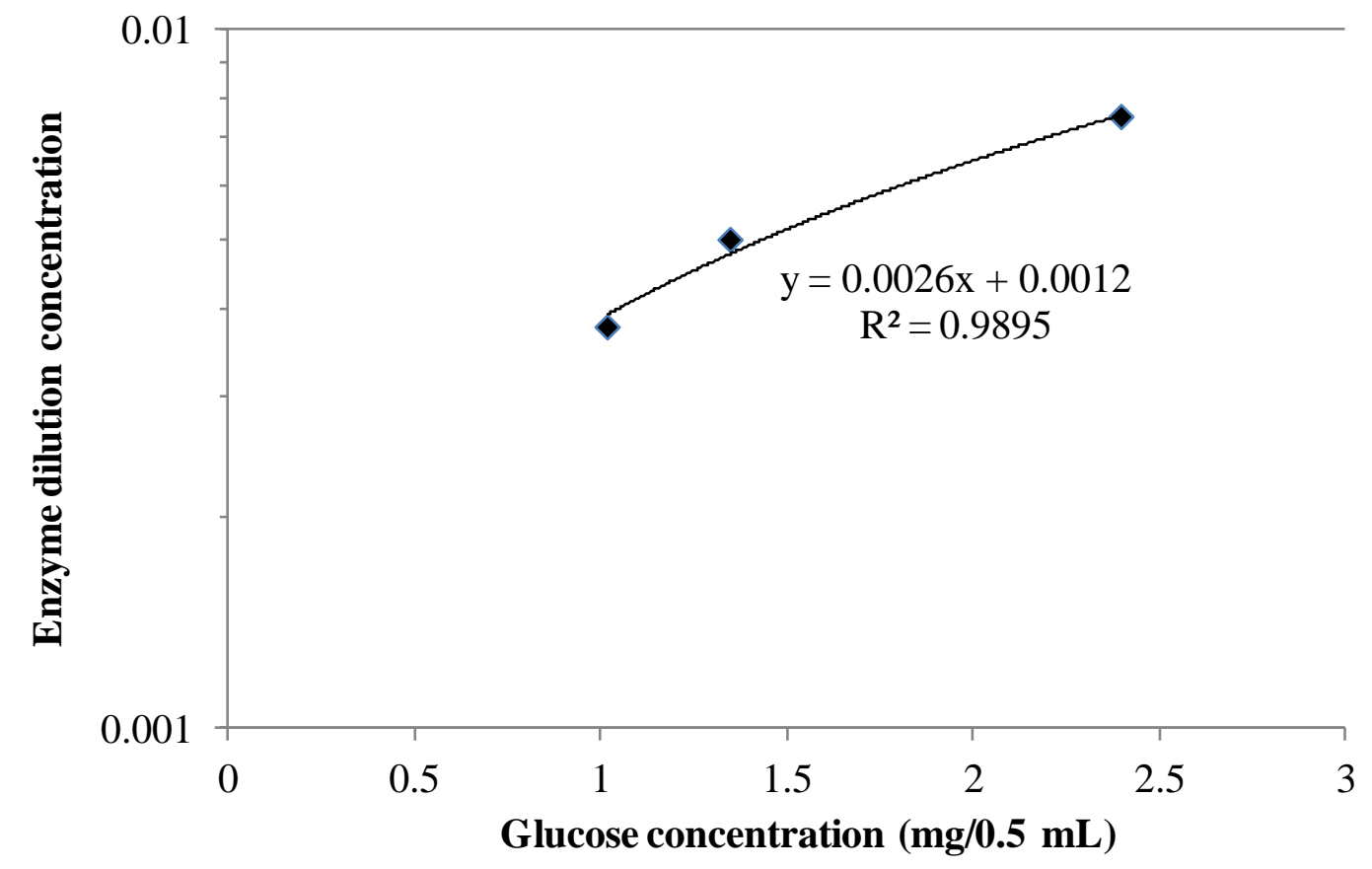

Figure D.7. Enzyme dilution concentration vs. Glucose concentration for $C b C t @ 45^{\circ} \mathrm{C}$

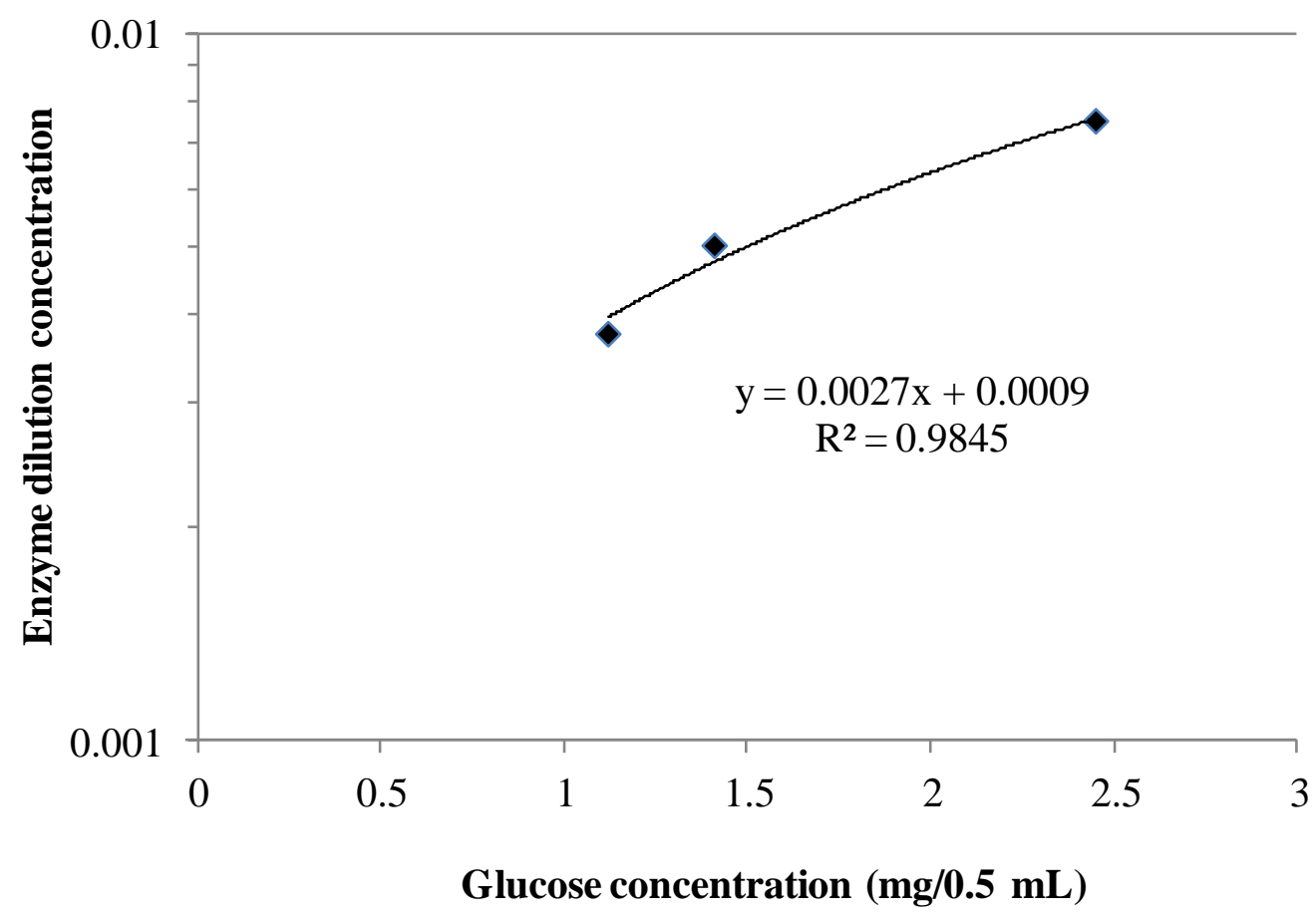

Figure D.8. Enzyme dilution concentration vs. Glucose concentration for $\mathrm{CaCt}$ (without enzyme) @ $45^{\circ} \mathrm{C}$ 


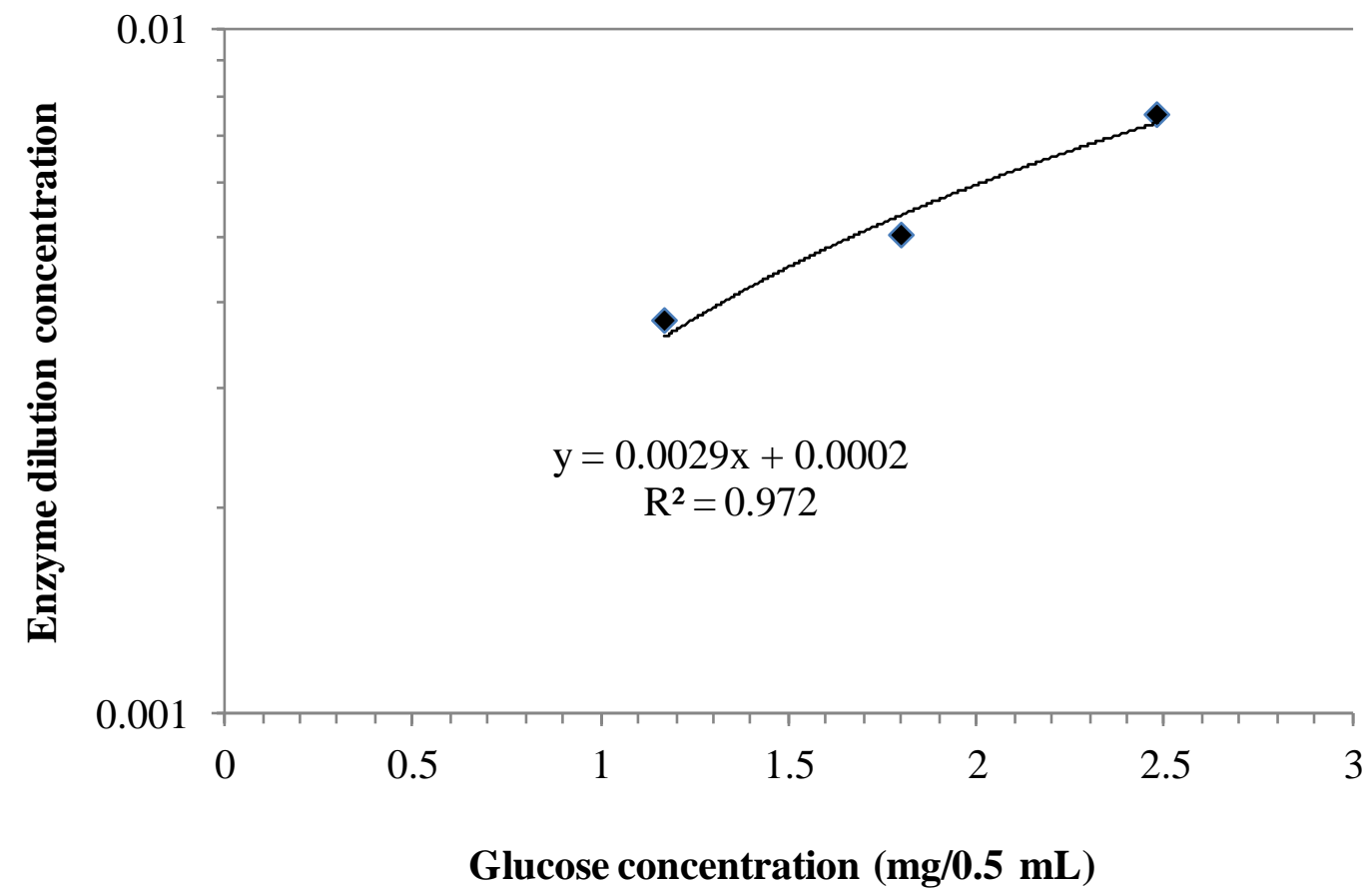

Figure D.9. Enzyme dilution concentration vs. Glucose concentration for $C b C t$ (without enzyme) @ $45^{\circ} \mathrm{C}$ 